\title{
Paraguay: 2009 Article IV Consultation-Staff Report; Public Information Notice on the Executive Board Discussion; and Statement by the Executive Director for Paraguay
}

Under Article IV of the IMF's Articles of Agreement, the IMF holds bilateral discussions with members, usually every year. In the context of the 2009 Article IV consultation with Paraguay, the following documents have been released and are included in this package:

- $\quad$ The staff report for the 2009 Article IV consultation, prepared by a staff team of the IMF, following discussions that ended on March 18, 2009, with the officials of Paraguay on economic developments and policies. Based on information available at the time of these discussions, the staff report was completed on April 20, 2009. The views expressed in the staff report are those of the staff team and do not necessarily reflect the views of the Executive Board of the IMF.

- $\quad$ A Public Information Notice (PIN) summarizing the views of the Executive Board as expressed during its May 1, 2009, discussion of the staff report that concluded the Article IV consultation.

- A statement by the Executive Director for Paraguay.

The document listed below has been or will be separately released.

Selected Issues Paper

The policy of publication of staff reports and other documents allows for the deletion of market-sensitive information.

\author{
Copies of this report are available to the public from \\ International Monetary Fund • Publication Services \\ $70019^{\text {th }}$ Street, N.W. • Washington, D.C. 20431 \\ Telephone: (202) 623-7430 • Telefax: (202) 623-7201 \\ E-mail: publications@imf.org・Internet: http://www.imf.org
}

\section{International Monetary Fund Washington, D.C.}





\title{
INTERNATIONAL MONETARY FUND
}

\section{PARAGUAY}

\section{Staff Report for the 2009 Article IV Consultation}

\author{
Prepared by the Staff Representatives for the 2009 Consultation with Paraguay \\ Approved by José Fajgenbaum and Daneshwar Ghura
}

April 20, 2009

\section{EXECUTIVE SUMMARY}

- Context. Following a period of stagnation and financial instability that led to a financial crisis in 2002, the authorities have been implementing strong macroeconomic and pro-growth policies, supported by two successive SBAs. The economy was successfully stabilized and began to grow well above average. A new administration took over in August 2008 promising more emphasis on social issues but the global financial crisis and political difficulties have delayed some of those plans.

- $\quad 2007$ Article IV consultation. The last Article IV consultation was concluded in June 2007. Directors stressed the importance of continuing to adhere to the strong macroeconomic policies in the authorities' program, as well as the structural reforms, including enhancing prudential regulations, strengthening the financial position of the Central Bank, sharpening expenditure control systems and improving the investment climate.

- 2008 Developments. The economy grew nearly 6 percent, but - as in many other countries - there was a noticeable deceleration in the last quarter. Inflation was contained at $71 / 2$ percent at end-2008 (the upper bound of the Central Bank's target). The fiscal position remained strong and the consolidated public sector reached a surplus of $2^{1 / 2}$ percent of GDP, owing to a large reduction in capital spending in 2008. Consistent with the pattern of commodity prices, the external position strengthened significantly in the first half of the year but weakened in the second half. Monetary policy was mostly accommodative and interest rates were reduced at the end of the year to provide liquidity to the banking system.

- 2009 Policies. To counter the adverse effects of the global crisis, the authorities have adopted an Economic Recovery Plan. The authorities and staff concurred that a relaxation of the fiscal stance and the continuation of a flexible monetary policy was appropriate. Staff recommended a deepening of ongoing structural reforms, especially to strengthen the financial position of the central bank, and to reinforce financial oversight and regulation, particularly of the large cooperative, pension fund and insurance sectors.

- Discussions took place during March 4-18, 2009. The mission met with Finance Minister Borda, Central Bank President Corvalán, Deputy Finance Minister Caballero, senior government officials, and representatives of the banking community and the private sector. The staff team consisted of P. Alonso-Gamo (head), M. Mlachila (WHD), S. Maziad (SPR), A. Lemgruber (FAD) and J. Gasha (MCM). A. Santos (WHD) joined the mission for a few days to introduce the new mission chief to the authorities. The mission was assisted by T. Roy, the Fund's resident representative in Asunción, and it liaised with World Bank and IDB staff. J. Maciel (OED) participated in the meetings. 


\section{LIST OF ACRONYMS}

\begin{tabular}{|c|c|}
\hline ANDE & National Electricity Company \\
\hline $\mathrm{BCP}$ & Central Bank of Paraguay \\
\hline $\mathrm{BNF}$ & National Development Bank \\
\hline CAR & Capital Adequacy Ratio \\
\hline $\mathrm{CCT}$ & Conditional Cash Transfer \\
\hline $\mathrm{CNV}$ & National Securities Commission \\
\hline COPACO & Public Telephone Company \\
\hline ESSAP & Public Water and Sewage Company \\
\hline FAD & Fiscal Affairs Department \\
\hline GDP & Gross Domestic Product \\
\hline GNFS & Good and Nonfactor Services \\
\hline HR & Human Resources \\
\hline IDB & Inter-American Development Bank \\
\hline IFI & International Financial Institutions \\
\hline IMAGRO & Tax on Agricultural Income \\
\hline $\mathrm{INC}$ & National Cement Company \\
\hline INCOOP & National Institute of Cooperatives \\
\hline IPS & Social Security System \\
\hline LRM & Central Bank Bills \\
\hline MOF & Ministry of Finance \\
\hline NDA & Net Domestic Assets \\
\hline NFPS & Non-Financial Public Sector \\
\hline NIR & Net International Reserves \\
\hline NPL & Nonperforming Loans \\
\hline OED & Office of the Executive Director \\
\hline PETROPAR & Public Petroleum Company \\
\hline PFM & Public Financial Management \\
\hline PIT & Personal Income Tax \\
\hline REER & Real Effective Exchange Rate \\
\hline SAS & Undersecretary of Social Action \\
\hline SBA & Stand-By Arrangement \\
\hline SDR & Special Drawing Rights \\
\hline SET & Tax Collection Agency \\
\hline SIB & Superintendency of Banks \\
\hline SOE & State-Owned Enterprises \\
\hline SPR & Strategy, Policy and Review Department \\
\hline VAT & Value Added Tax \\
\hline WB & World Bank \\
\hline WHD & Western Hemisphere Department \\
\hline
\end{tabular}




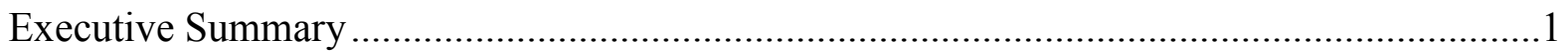

I. Economic, Political, and Social Background.........................................................4

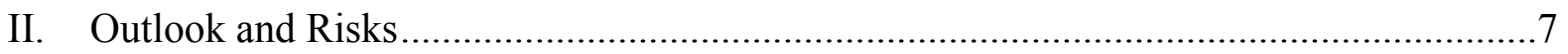

III. Policy Discussions ............................................................................................... 7

A. Short-Term Policies to Address the Economic Slowdown and Spillovers from the Global Economic Crisis ................................................................... 10

B. Policies to Enhance the Financial Sector .........................................................14

C. Medium-Term Policies to Sustain Growth and Reduce Poverty .............................18

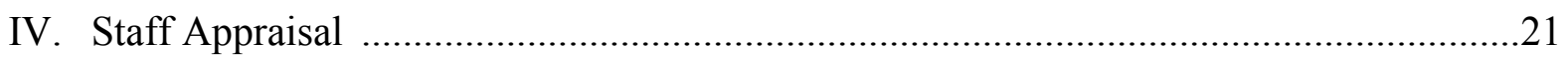

\section{Text Boxes}

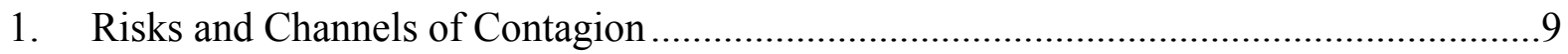

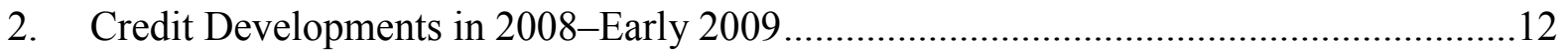

3. Exchange Rate Assessment............................................................................... 13

4. Lessons from Previous Banking Crises, 1995-2003 .............................................. 17

\section{Figures}

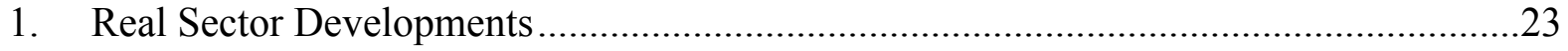

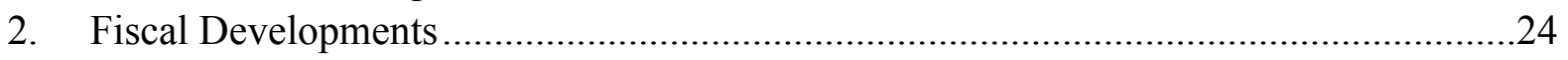

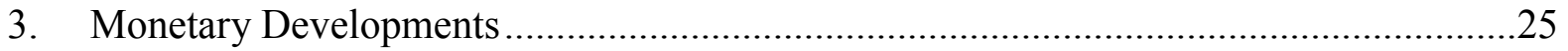

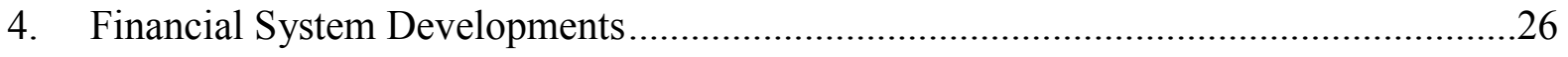

5. Balance of Payments Developments........................................................................27

\section{Tables}

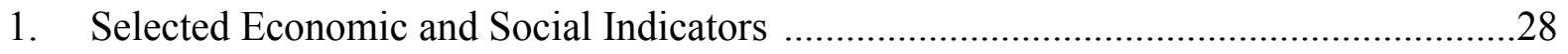

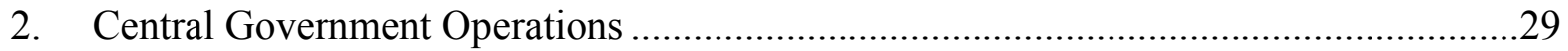

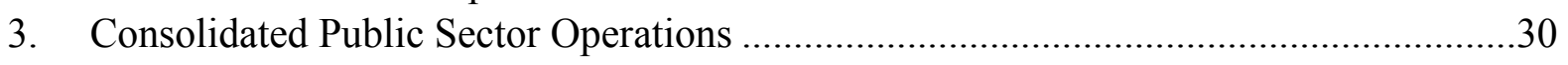

4. Summary Accounts of the Central Bank, 2006-14 ...................................................31

5. Summary Accounts of the Banking System, 2006-14 .............................................32

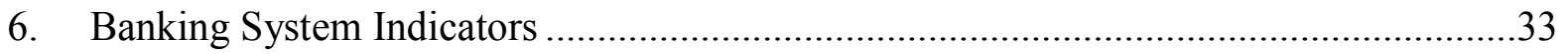

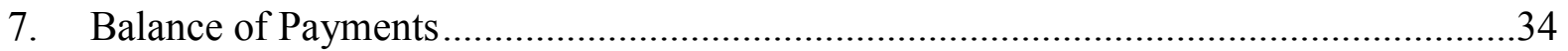

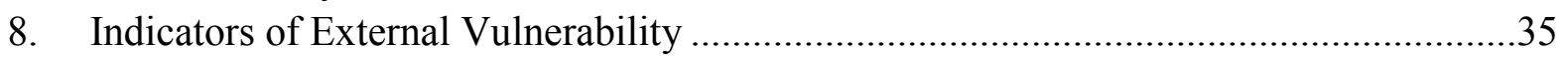

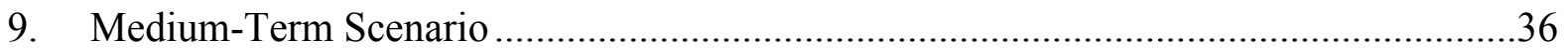

\section{Appendixes}

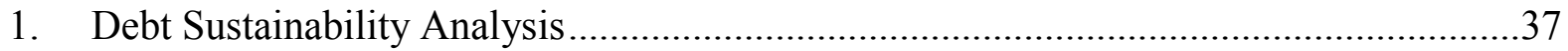

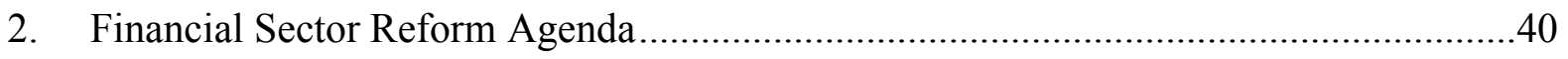




\section{EConomic, Political, AND Social Background}

1. Context. The rapid deterioration in the global environment has started to affect the region, including Paraguay. The Paraguayan economy performed very well over the past five years, with real GDP growth averaging about 5 percent annually - the best in a generation. The fiscal position strengthened considerably, reducing public debt sharply and bringing the debt ratio to relatively low levels. Throughout this successful period, Paraguay was supported by two successive Fund arrangements. With the rapidly deteriorating global economy, however, short-term economic prospects have significantly worsened.

2. Output. Real GDP growth is estimated to have reached nearly 6 in 2008, after a record performance of $63 / 4$ percent in 2007 . Growth accelerated to about $7 \frac{1}{2}$ percent in the first half of 2008, supported by the continued expansion of the primary sector and the diversification of growth to the manufacturing and services sectors. In the second half of the year, growth slowed to some $3 \frac{1}{2}$ percent, reflecting the loss of export market shares for the meat sector, the sharp decline of commodity prices (mainly soybeans), a drought in the last quarter, and difficulties in the manufacturing sector. As a result, the economic slowdown

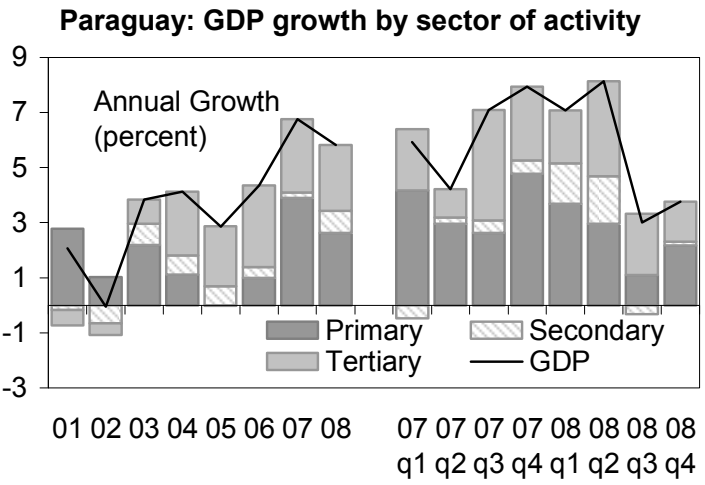
became apparent earlier in Paraguay than in other countries in the region.

3. Inflation. Headline inflation rose to 12 percent (y-o-y) in June 2008, mostly due to energy and food supply shocks, but ended at $71 / 2$ percent in December 2008 (within the Central Bank's target) as those shocks unwound. The rise in energy and food prices, in the context of an accommodative monetary stance, spilled over into a wide range of prices, raising core

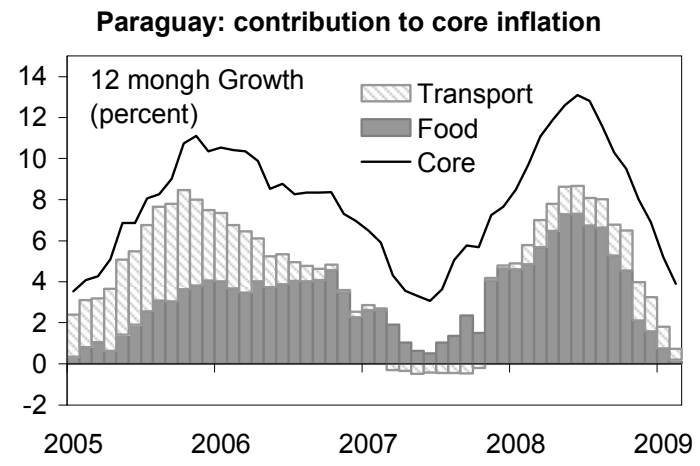
inflation ${ }^{1}$ by about 10 percentage points in the 12 months through June 2008. Since January 2009, inflation has fallen considerably, to 3.4 percent (y-o-y) at end-March, reflecting in part a large decline in import prices.

\footnotetext{
${ }^{1}$ The measure of core inflation used by the Central Bank excludes fruits and vegetables but includes fuels and other food items.
} 
4. Fiscal. Fiscal policy was strong and counter-cyclical in 2008. Revenue performance was remarkable, notwithstanding lower royalties.

Tax revenues grew by about 12 percent in real terms (about 1 percent of GDP), owing to the strong economy and improved tax and customs administration. At the same time, while current expenditures were kept under control, there was a sharp decline in capital expenditure execution in the second half of 2008. This was mainly due to cement shortages and a reassessment of the investment priorities by the new administration. As a result, the central government recorded a surplus of about $2 \frac{1}{2}$ percent of GDP, compared to a surplus of

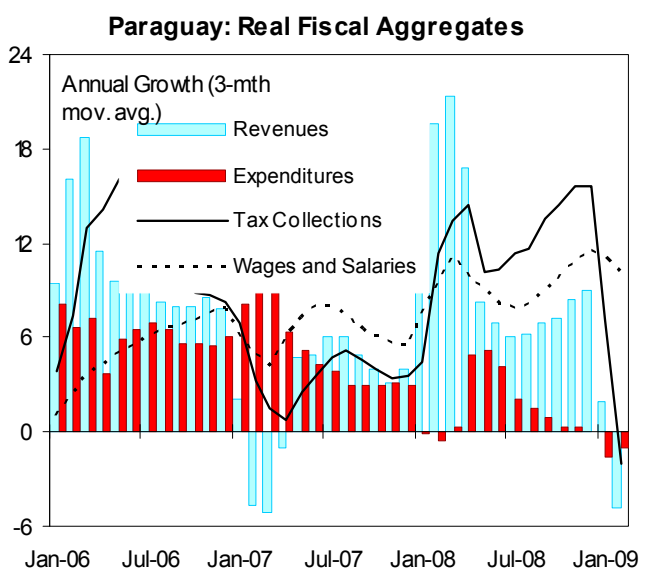
1 percent in 2007. Tax revenue performance significantly worsened in the first two months of 2009, due in part to a sharp decline in customs revenue.

5. Monetary. Monetary policy remained accommodative throughout 2008. In particular, credit growth peaked at 75 percent and currency growth at 40 percent-fueled until mid-2008 by large foreign exchange flows that were only partially sterilized. These flows started to reverse in July 2008, as export prices fell. Initially, the monetary authorities tried to support the guarani, while commercial banks continued to expand credit by using free reserves at the central bank and redeeming sterilization paper. The turning point came with the worsening of the global financial crisis in October 2008, when the financial sector experienced some liquidity strains. The central bank responded swiftly by: (i) reducing reserve requirements; (ii) introducing a short-term liquidity facility; and (iii) lowering the policy interest rate. The intervention policy was also modified to allow for greater exchange rate flexibility. Nevertheless, commercial banks continued to build free reserves at the Central
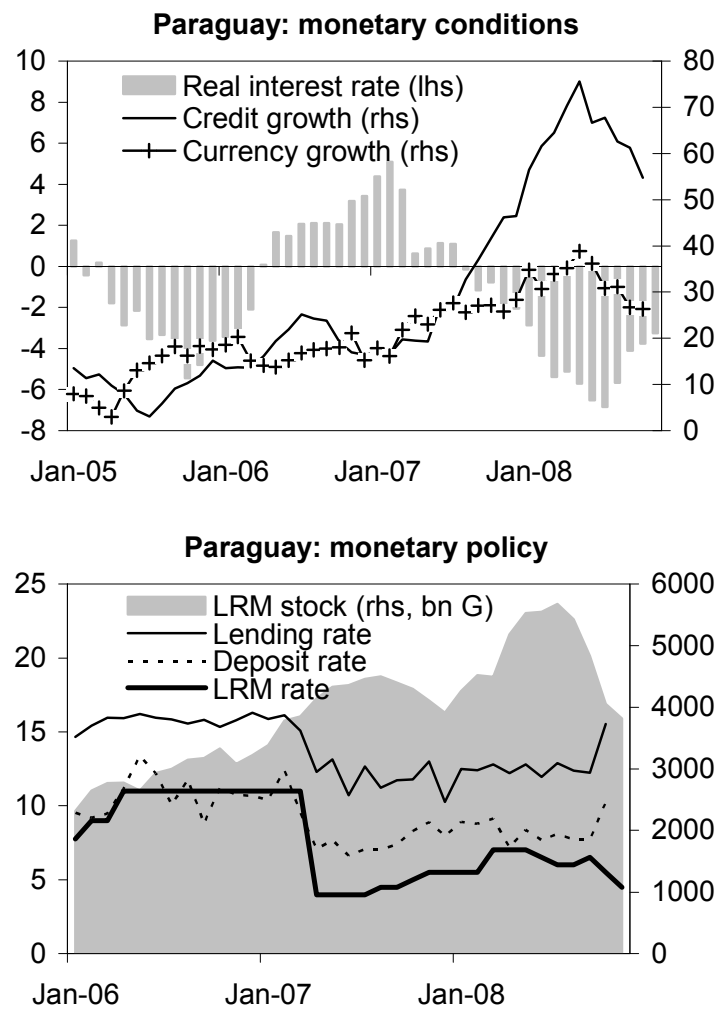
Bank while the growth of currency in circulation dropped to 1 percent by March 2009. At the same time, the public sector position with the banking system strengthened further. 
6. Financial. The impact of the global financial crisis has been relatively muted thus far, reflecting not only the low integration of Paraguay with global financial markets reflected in the limited exposure to foreign assets and liabilities of its financial sector, but also the strengthening of the banking system over the last few years. Nonetheless, while financial soundness indicators of the banking Financial Soundness Indicators: Banking System

\begin{tabular}{lrrrrr}
\hline & \multicolumn{1}{c}{2004} & \multicolumn{1}{c}{2005} & \multicolumn{1}{c}{2006} & \multicolumn{1}{c}{2007} & \multicolumn{1}{c}{2008} \\
\hline Regulatory Capital to Risk Weighted Assets & 20.5 & 20.4 & 20.1 & 16.8 & $16.21 /$ \\
Bank Capital to Assets & 10.5 & 11.0 & 12.5 & 11.6 & 11.2 \\
Nonperforming Loans & 10.8 & 6.6 & 3.3 & 1.3 & 1.2 \\
Provisions to Nonperforming Loans & 54.6 & 57.7 & 59.1 & 78.2 & 77.7 \\
ROA & 1.7 & 2.1 & 3.0 & 2.8 & 3.5 \\
ROE & 18.3 & 22.6 & 31.7 & 34.7 & 31.4 \\
Foreign Exchange Deposits to Total Deposits & 55.0 & 52.7 & 49.1 & 44.3 & 44.4 \\
Liquid Assets to Total Assets & 30.8 & 26.6 & 23.3 & 24.3 & 23.5 \\
Source: BCP & & & & &
\end{tabular}
system remain adequate, liquidity and asset quality indicators have shown some weakening. ${ }^{2}$

- Credit growth has decelerated, but remains high. After reaching about 75 percent in mid-2008, the growth of credit to the private sector decelerated to 40 percent in February 2009.

- $\quad$ Preference for liquidity has increased. Demand for guarani and dollar liquidity has increased, and banks have redeemed their holdings of maturing sterilization paper (LRMs).

7. External. The external position was very strong throughout the first half of 2008, but started to weaken as the global slowdown and financial crisis unfolded, with the current account shifting to a deficit and external credit lines to the private sector being reduced. As a result, the current account recorded a deficit of $1 \frac{1}{2}$ percent of GDP in 2008. Exports started declining in September 2008, in particular meat exports, whose main markets practically closed because of oversupply and import substitution from other countries. Imports also decelerated on account of lower oil prices and lower demand for agricultural sector inputs. The foreign exchange market was under pressure during August-November 2008 and, to ease pressures, the Central Bank sold some US\$400 million (80 percent of all foreign currency purchases accumulated during the first half of the year). During August-October 2008, the guarani, which had appreciated by 23 percent between end-2007 and June 2008, was allowed to slide back to its level at the beginning of the year. Net international reserves stood at US \$2.86 billion at end-2008 (430 percent of short-term debt on a remaining basis), and have remained stable since. There has been some progress in resolving external disputed claims. $^{3}$

\footnotetext{
${ }^{2}$ Liquidity ratios (measured by the ratio of liquid assets, comprising cash, reserves, accounts in banks and lending in interbank market, to total assets) showed a modest deterioration from 24.3 percent at end-2007 to 23.5 percent at end-2008. Nonperforming loans nearly doubled, from G371 billion to G714 billion during the same period.

${ }^{3}$ The Paraguayan authorities are currently defending themselves in the case brought against them by import verification companies at the World Bank's International Center for Settlement for Investment Disputes.
} 
8. Politics. After 61 years of uninterrupted government by the Colorado Party, President Lugo was elected last year on a platform for change, social justice, and fight against corruption, with the goal of addressing deep-seated poverty issues, by increasing social and infrastructure expenditure, while maintaining growth and macroeconomic stability. The government lacks a majority in Congress, however, rendering difficult the implementation of the ambitious reform agenda. Plans to reactivate the economy with the help of external financing may face difficulties in getting approved by Congress.

9. Social. Paraguay's poverty rate remains high, and the social situation is now deteriorating due to the economic slowdown, even if the decline of food and energy prices in recent months brought moderate relief to poor households. Falling commodity prices and the drought have worsened living conditions for poor peasants and farm workers, and the government had to quell social unrest among sesame farmers by promising financial emergency aid. In the urban areas, faltering economic activity is causing business failures and layoffs. ${ }^{4}$

\section{OUTLOOK AND RISKS}

10. Paraguay is confronting the challenges of the global economic slowdown from a position of relative strength, as a consequence of the sound policies pursued in recent years. These policies have led to solid growth, continuous budget surpluses, significantly lower public debt ratios, and a remarkable increase in international reserves. However, the economic outlook has significantly worsened, largely because of the sudden change in the external environment and a regional drought. Growth has decelerated sharply and the external accounts have come under strain, with lower imports leading to a drop in tax revenue in early 2009 .The legacy of two years of very rapid credit expansion could lead to a deterioration in bank portfolios. Moreover, experience suggest, contagion from Brazil and Argentina poses a major risk (Box 1). Should economic conditions deteriorate further, the government's lack of a majority in Congress could complicate efforts to attain political consensus on tough decisions, and there may be pressures to follow populist policies.

\section{Policy Discussions}

11. Focus. The discussions focused on policies that could help limit the negative impact of the global economic slowdown and financial crisis, and return quickly to a higher and sustainable growth path, safeguarding the hard-fought economic gains. Although the impact of the global crisis has been relatively limited to date, the projected sharp decline in Paraguay's growth rate is likely to put to considerable strains on the financial sector.

\footnotetext{
${ }^{4}$ In a recently published study, the UNDP estimated that in the absence of decisive policy measures extreme poverty would rise from 19.4 percent of the population (2007) to 22.5 percent during 2009 , reversing any gains that were achieved during recent years of high economic growth.
} 
12. Authorities' plan. To help limit the adverse effects of the global crisis, the authorities have adopted an Economic Reactivation Plan. The plan is set in a medium-term context, with measures to address immediate challenges as well as medium-term structural weaknesses. As a first step, it envisages implementing fully the 2009 budget approved by Congress, which is more expansionary than the one submitted by the executive in September 2008 - without introducing cut-backs via a financial plan. The budget envisages an overall deficit of $3 / 4$ percent of GDP. ${ }^{5}$ Key elements of the plan include: (i) implementing a fiscal stimulus in 2009-10, mainly by increasing significantly capital expenditures and conditional cash transfers (CCT); (ii) increasing liquidity available to the banking system to facilitate lending; (iii) obtaining higher levels of external financing from international financial institutions (including contingency credit lines); and (iv) addressing medium-term structural issues, including public financial management and control, and financial sector reforms.

13. Against this background, the policy dialogue focused on three themes:

- Short-term fiscal and monetary policies to sustain domestic demand during the downturn while preserving stability.

- Policies geared to strengthen the banking system in the face of a slowdown of economic activity, while reinforcing preparedness against spillover risks of the global credit crunch.

- Medium-term structural policies to sustain growth and reduce poverty through a carefully planned reform agenda.

\footnotetext{
${ }^{5}$ In the past, the executive had to resort to implementing a financial plan aimed at containing the budget approved by Congress within reasonable limits.
} 


\section{Box 1. Paraguay: Risks and Channels of Contagion}

Paraguay enters the current episode of financial turbulence from a much stronger position that in previous crises. Reserve coverage of short-term debt is three times higher than in 2001 (but import coverage is broadly the same), while external public debt as a percent of GDP is half the level of seven years ago. The banking system has also strengthened; with the NPL ratio at 1 percent in 2008 against 21 percent in 2003 and the return on assets has increased from 0.4 to $3 \frac{1}{2}$ percent. However, the global economic slowdown and financial crisis bring considerable risks.

Trade linkages have increased while direct financial linkages have marginally decreased.

- Trade openness (measured as the sum of total exports and imports) has increased by half, to nearly

70 percent of GDP. The increase reflects in part the expansion of primary commodities (soy) and other primary exports (meat), for which Paraguay directly competes with its immediate neighbors from MERCOSUR. Its dependence on imports from

MERCOSUR has declined while exports to the region have been stable.

\section{- By contrast, financial linkages have somewhat} decreased ${ }^{1}$, as the share of assets of direct foreign subsidiaries in total bank assets declined from 40 percent to 20 percent between 2001 and Table. Trade and financial integration of Paraguay, in percent of GDP

\begin{tabular}{lrrrrrrr}
\hline & 2001 & 2008 & \multicolumn{5}{c}{ Share of main partner in 2008 (\%) 1/ } \\
\cline { 3 - 8 } & & & Brazil & Argen. Spain & USA & Other \\
\hline Exports 2/ & 15.3 & 24.5 & 17 & 19 & $\ldots$ & $\ldots$ & 64 \\
o.w. primary products (\%) & 75 & 82 & & & & & \\
Imports 2/ & 30.8 & 44.9 & 29 & 13 & $\ldots$ & $\ldots$ & 58 \\
Remittances & 1.4 & 1.3 & 0 & 6 & 45 & 36 & 13 \\
Stock of FDI & $\ldots$ & 9.9 & 14 & 7 & 4 & 38 & 36 \\
Private sector credit & 26.1 & 22.3 & 22 & 1 & 28 & 5 & 44 \\
O.w. foreign ownership (\%) & 82 & 66 & & & & & \\
\hline
\end{tabular}

$1 /$ Exports by destination, imports by origin, bank credit by ownership (direct subsidiary or majority-foreign owned bank). 2/ Registered trade only.

2008, the share of majority foreign-owned banks increased from 42 percent to 46 percent.

- Vulnerabilities remain. Despite reduced direct financial linkages and thin undeveloped capital markets, the deterioration of global sentiment in late 2008 (combined with the sharp decline in commodity prices) has considerably affected Paraguay.

The impact of the 1998 Brazil crisis and the 2001 Argentina crisis on Paraguay provides some insights to which extent the country could be affected if regional conditions deteriorate further. Although the nonagriculture GDP contraction was smaller the year following the Argentinean crisis than after the Brazilian crisis (-1.3 against -2.1 percent respectively), the impact on the banking sector (with a loss of 30 percent of deposits) and on the exchange rate was more severe. Paraguay weathered better the Brazilian crisis because of a number of factors: the magnitude of the depreciation in Argentina was larger than the one in Brazil; the 2001 crisis spilled over into the domestic banking system through a local subsidiary of an Argentinean bank; six months after the start of the Brazilian crisis, Paraguay benefited from a large loan from Taiwan, allowing it to revert its contractionary interest rate defense. Similar specific factors would also matter this time, should conditions deteriorate.

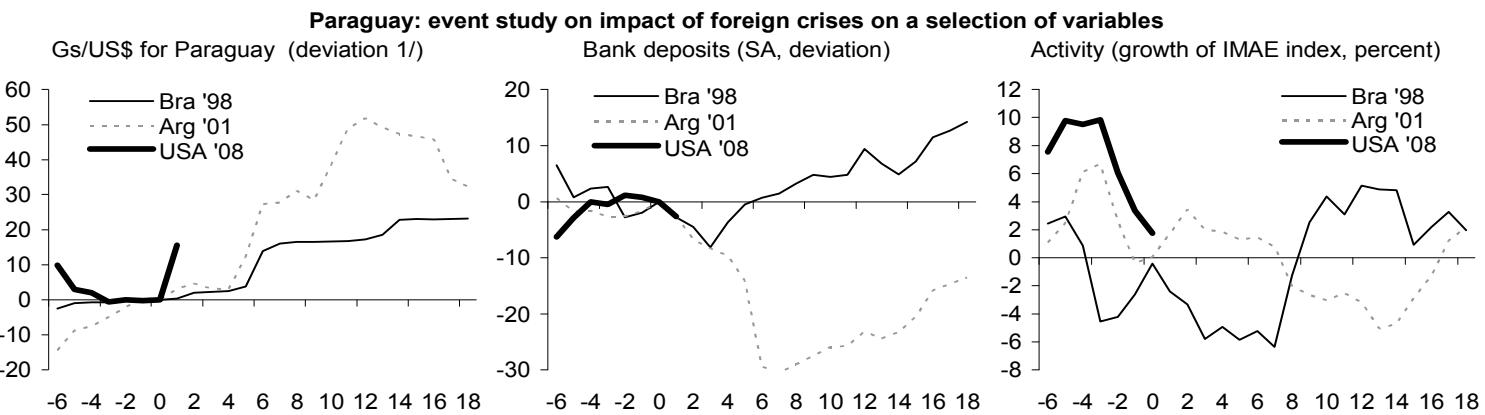

1/ Deviation from baseline month: Dec. 1998 for Brazilian crisis; Dec. 2001 for Argentinian crisis; Sept. 2008 for subprime crisis.

${ }^{1}$ There is little information on short-term financing provided directly by agro-exporters, less so on their evolution over time. Some estimates suggest that they could represent about half of total bank credit. 


\section{A. Short-Term Policies to Address the Economic Slowdown and Spillovers from the Global Economic Crisis ${ }^{6}$}

14. Macroeconomic outlook. In the wake of the global recession, Paraguay's real GDP is expected to decline to about $1 / 2$ percent in 2009 before recovering very gradually towards its long-term growth potential. The sharp slowdown is due to the large negative terms-oftrade shock and a regional drought, affecting agriculture and decelerating both investment and private consumption. The output gap is expected to turn negative in 2009 (about 3 percent of GDP), with considerable downside risks. Inflation is expected to decline from $71 / 2$ percent at end-December 2008 to $5 \frac{1}{2}$ percent by end-2009, before declining to 5 percent by 2010 . Downward pressures from the unwinding of the food and energy supply shocks, combined with a decelerating demand, would be partly offset by higher imported inflation and inflation inertia. The external current account deficit is expected to improve to 1 percent of GDP in 2009, reflecting much lower imports.

15. Fiscal stimulus. In the face of a weakening economy, staff concurred that there is scope for fiscal easing. Given the comfortable and sustainable public debt situation (below 20 percent of GDP, see Appendix 1), the authorities can afford a targeted fiscal stimulus of about 3 percent of GDP for 2009. Although automatic stabilizers would contribute to some extent (mainly through lower tax collections), the authorities are envisaging a discretionary fiscal expansion, covered by external financing from the World Bank, IDB and other IFIs. ${ }^{7}$ The authorities would scale back spending plans in the event of shortfalls in the expected financing. Given that the crisis is likely to be protracted, staff recommended formulating policies in a medium-term context, lining up the necessary financing for the period. Staff advocated renewed efforts in executing the capital

Fiscal stance, fiscal impulse and output gap (Base year 1994) budget, improving inter-ministerial coordination, and higher social spending, including substantial increases in outlays for the conditional cash transfer (CCT) program. Moreover, in light of the current decline in tax revenue, there is need to continue to improve tax administration and resist tax concessions. The authorities agreed and expressed concern about political pressures to increase current expenditures and introduce tax concessions. ${ }^{8}$

\footnotetext{
${ }^{6}$ This sub-section draws on Mlachila and Monfort, 2009, “Assessing the Appropriateness of Monetary and Fiscal Policies in an Adverse Environment” Selected Issues Paper.

${ }^{7}$ The World Bank could provide additional resources of US\$100 million, the IDB could make available loans up to US\$250 million (including an emergency credit line); several international donor agencies have significant approved but undisbursed loan portfolios.

${ }^{8}$ Congress considers introducing unfunded old-age pensions, increasing fiscal incentives for companies that hire new staff, and delaying the introduction of the PIT.
} 
Staff expressed concern about the inclusion in the approved budget of yet another sharp increase in the wage bill (about 16 percent compared to the outcome for 2008). ${ }^{9}$

16. Monetary policy. Staff supported the relatively accommodative monetary stance at current policy rates (reduced by 200 basis points in October and November 2008), but cautioned against excessive further liquidity injections (Box 2). The authorities argued in favor of prudent monetary easing to facilitate loan repayments in view of sharply lower export revenues. Since September 2008, credit growth rates have been declining, due to the economic slowdown and an increase in lending rates. Banks have become more cautious in lending - preferring to hold higher levels of liquidity ${ }^{10}$. Staff noted that an excessive increase of liquidity could put pressures on the exchange rate and stressed that the authorities had to be prepared to tighten policy if there was evidence of excess demand in the foreign exchange market and/or if inflation pressures reappeared. ${ }^{11}$ In the event of liquidity shortages due to unexpected financial system distress, staff agreed that there is scope for a further temporary easing of monetary conditions through a new facility for collateralized short-term lending, The authorities and staff agreed that using international reserves to fund fiscal expenditures, as proposed in Congress, should be firmly resisted.

17. Exchange rate flexibility. The authorities and staff concurred that the exchange rate should remain flexible to facilitate adjustment in the face of external shocks and fundamentals. Staff estimates that the guarani is broadly in line with fundamentals (Box 3) and that exchange rate policy since October 2008 has been appropriate, as limited interventions help avoid a disorderly adjustment that could jeopardize the stability of the dollarized banking system, while preserving the reserve cushion. Staff stressed the need to avoid unsterilized intervention through domestic liquidity injections, as such a policy would fuel outflow pressures.

\footnotetext{
${ }^{9}$ The executive's budget proposal envisaged no increase in salaries (except for wage drift), but an increase by 5 percent, plus additional hiring of staff and increased benefits in the health sector and police introduced by Congress have inflated the overall wage bill.

${ }^{10}$ Higher than the normal level of excess liquidity. The latter is explained by structural inefficiencies in the interbank market. Planned reforms in the payments system should alleviate this problem.

${ }^{11}$ About 45 percent of liquid assets in guaranís and the rest in U.S. dollars.
} 


\section{Box 2. Paraguay: Credit Developments in 2008-Early 2009}

Credit grew rapidly during the first half of 2008., fueled by negative real interest rates since mid-2007. Bank credit to the private sector (in guaranis and dollars) has expanded strongly, peaking at 75 percent $(\mathrm{y}-\mathrm{O}-\mathrm{y})$ in May 2008. Credit expansion was mainly directed to the fastest growing sectors: agriculture and trade. Bank credit was also complemented by crop pre-financing credit lines by international commodity trading companies, such as Cargill.

\section{Credit expansion continued at the same pace in Q3,} despite growing signs of a worsening economic environment. Foreign exchange inflows were declining while deposits in commercial banks stagnating, and subsequently declining. There was a reduction in LRMs, reflecting both lower supply and demand, with less need to sterilize given the decline of NIR, and less appetite for LRMs given the desire to continue expanding private sector credit, which carried higher rates. Banks also made increasing use of their free reserves at the central bank.

The situation changed drastically in October 2008. With the deterioration of market sentiment and a consequent cut in external credit lines, the central bank shifted to allow greater exchange rate flexibility while decreasing reserve requirements and reducing the policy rate. Commercial banks started to accumulate a buffer of higher reserves by continuing to reduce their outstanding stock of LRMs, and kept credit to the private sector broadly flat. ${ }^{1}$ Deposits declined by about 3 percent.

Although modest at the aggregate level, the reversal was severe for some of the smallest banks. Three banks representing about 20 percent of the banking system experienced a monthly loss of deposits larger than 7 percent, leading them to reduce its lending activity. The pattern of deposit loss suggest flight to quality while the expansion of credit by some banks (mostly foreign banks) reflected an extension of interbank credit in favor of the most affected institutions. Broadly speaking, there seems to have been a limited credit crunch that affected some of the smaller, domestically-owned banks. Since October, liquidity pressures have declined for all banks. The main problem affecting all banks is the structural shortage of longer-term liquidity.
Exchange rate and EMBI spread in 2008

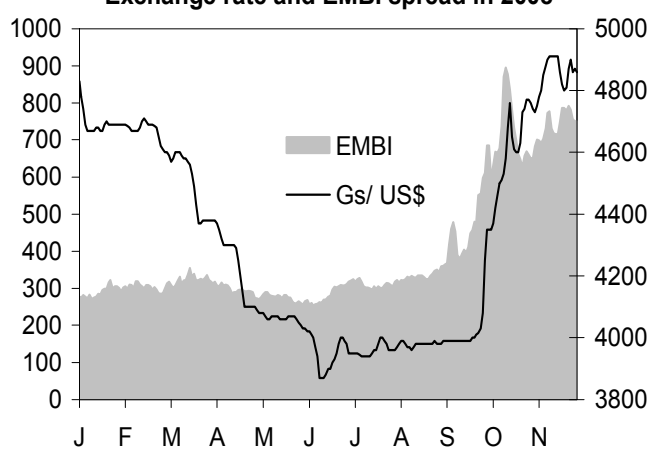

NIR and sterilization paper (LRM) in 2008

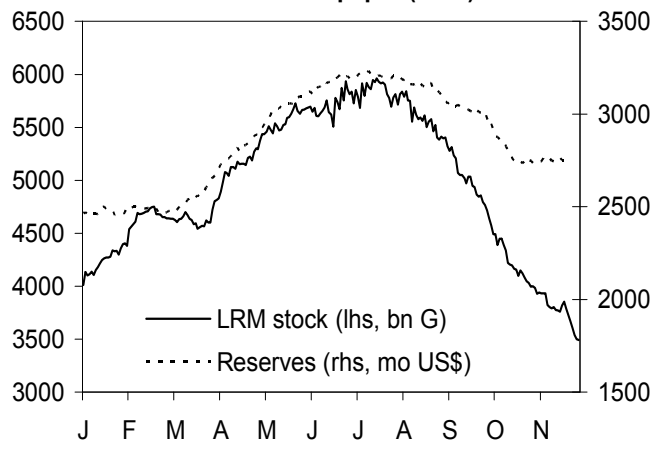

Required and free reserves by currency in 2008

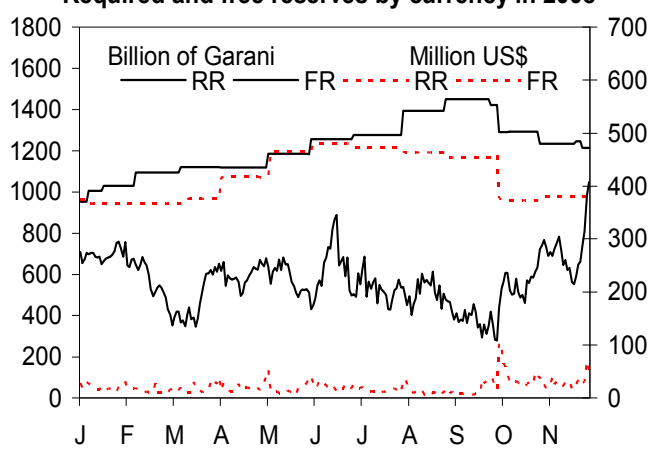

Change in deposit and credit by bank in Oct. 1/

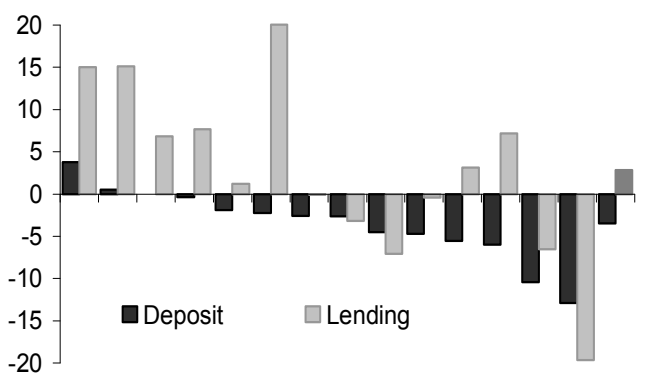

$\begin{array}{llllllllllllll}7 & 9 & 5 & 4 & 12 & 11 & 8 & 14 & 3 & 1 & 2 & 6 & 10 & 13 \mathrm{Avg}\end{array}$ $1 /$ Banks ranked by deposit loss (at constant exchange rate) in October over September. The numbers identify the banks classified by market share ( 1 = largest bank) 


\section{Box 3. Paraguay_Exchange Rate Assessment}

Using CGER-type methodologies, ${ }^{1}$ the assessment suggests that, as of end-2008, the guarani was broadly in line with fundamentals, with an estimated overvaluation of 1-5 percent. The REER had been falling until 2005, when that trend was reversed and the REER rose by about 30 percent by end-2007. The nominal exchange rate has fallen by almost 25 percent in the last quarter of 2008 , while the REER declined by about 5 percent. By February 2009, the guaraní depreciated by a further 3.3 percent, which brings the currency more in line with fundamentals.

The macroeconomic balance (MB) approach also suggests that the guaraní is

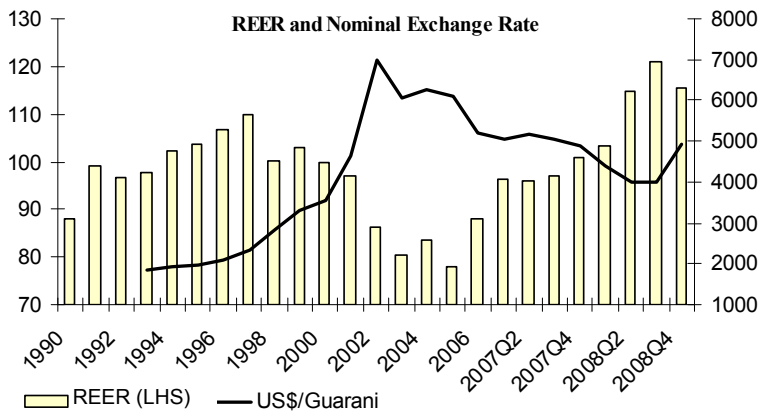
in line with fundamentals, with virtually no overvaluation in the medium term. The estimated current account (CA) norm was about zero percent of GDP, while the underlying current account deficit in 2008 is estimated at -0.4 percent (after stripping the effect of the peak in oil prices). Using the standard CGER trade elasticities, eliminating the gap between the estimated CA norm and the underlying current account deficit in 2008 would require a real depreciation of about 1 percent.

The external sustainability (ES) approach suggests an overvaluation of about 3.5 percent in the medium term. In the ES approach, the sustainable current account deficit, which stabilizes the NFA position at the 2007-08 average, is estimated at 1 percent of GDP. A real depreciation of about 3.5 percent would close the trade account gap of 1.3 percent between the equilibrium and the projected trade balance.

The equilibrium real exchange rate (ERER) approach suggests that, as of end 2008, the guarani was broadly in line with fundamentals with an

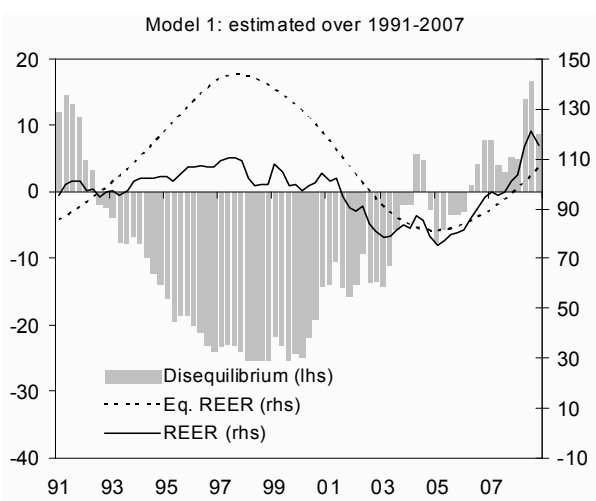
estimated overvaluation of some 6-8 percent. Using cointegration analysis over the period 1990Q1-2007Q2, a long-run relation was obtained between Paraguay's REER and fundamentals, including: terms of trade, productivity differential, trade openness, fiscal balance, CA balance, and NFA. The resulting ERER points to an overvaluation of the actual REER of about 8 percent at the end-2008. Re-estimating the equation over a shorter time period (1991Q1-2001Q4) to eliminate the effect of an extended period of undervaluation on the equilibrium REER results in a smaller estimated overvaluation of about 6 percent. $^{2}$

\footnotetext{
${ }^{1}$ These methodologies take a holistic approach in assessing the exchange rate by using three approaches: (i) the macroeconomic balance; (ii) the external sustainability; and (iii) the equilibrium real exchange rate. For details on the methodologies see (http://www.imf.org/external/np/pp/eng/2006/110806.pdf) and "Exchange Rate Assessment: CGER Methodologies", IMF Occasional Paper 2008, no. 261.

${ }^{2}$ For further details on the ERER approach applied to Paraguay, see Barkbu and Monfort, 2009, "Is the Exchange Rate Overvalued?" in Santos, Editor, Paraguay: Addressing the Stagnation and Instability Trap.
} 


\section{B. Policies to Enhance the Financial Sector ${ }^{12}$}

\section{Staff emphasized that further strengthening the financial sector should be an integral part of the Economic Reactivation Plan. Noting that Paraguay had suffered from} five consecutive financial crises during the period 1995-2003, with considerable economic dislocation and fiscal costs, staff stressed that the framework for crisis mitigation and resolution needed updating and strengthening, drawing on Paraguay's own historical experience (Box 4). Staff recommendations drew on the Fund's cross-country experience and best practices in dealing with financial sector issues and contingency planning, including:

- Cooperatives. Financial cooperatives are steadily increasing their participation in the financial system - accounting for approximately 25 percent of deposits and almost 28 percent of credits by end-2008 - but are lightly supervised. The "General Regulatory Framework for Cooperatives", which entered into effect in 2007, aimed at establishing capital requirements, classification of loans and provisioning requirements, liquidity requirements, as well as introducing a basic framework for carrying out effective supervision. However, an effective framework is still being developed, as norms governing the operations of cooperatives are less stringent than those for banks and finance companies. There is therefore a need of significant action in these areas without delay. Priorities in this area include (i) strengthening supervision and auditing regulations; (ii) improving the system of statistics and data analysis; and (iii) enhancing the administrative and operational capacities of the supervisory agency (INCOOP).

- $\quad$ Protection of depositors. A deposit guarantee fund (FGD) was created in December 2003. While depositors paid their contributions, the government has fallen behind in its commitment to bolster the FGD's capital base. Staff encouraged the authorities to honor promptly the financial commitments to the FDG, so as to enhance the resilience and credibility of the deposit insurance system. ${ }^{13}$

- Bank restructuring and resolution. The framework for restructuring and resolution has some shortcomings. In particular, the responsibility for the ultimate liabilities in case of bank intervention needs to be clarified. Since end-2008, staff of the

\footnotetext{
${ }^{12}$ Financial sector reforms have received extensive technical assistance from the Fund (e.g., central bank recapitalization, prudential regulation and supervision, see Information Annex), and from the World Bank (payments system).

${ }^{13}$ The fund is currently worth US\$80 million, of which US\$60 million is in cash (deposits at BIS of US\$50 million and US\$10 million in local currency deposits at the BCP). As of February 2009, the Fund covered about $1 \frac{1}{2}$ percent of total deposits and 4 percent of eligible deposits, well short of the 10 percent target set by law. According to the 2003 original FGD law, the government is expected to contribute about US\$50 million in interest-free, non-negotiable bonds, but so far has only contributed US\$20 million.
} 
Superintendency of Banks (SIB) is covered by an insurance against personal liability in cases of bank intervention and resolution, but the SIB also needs formal powers to apply administrative sanctions and remedial procedures. Staff noted that any restructuring event should aim at consolidating the financial system, while ensuring that public financial support is repaid over time.

- $\quad$ Foreign exchange pressures. In a dollarized economy, the central bank's foreign exchange position should be seen to be strong enough to withstand a sudden increase in the public's preference for foreign currency. As noted by the 2005 FSAP report, the large proportion of unhedged borrowers and the difficulty in executing collateral suggest that foreign-exchange-induced credit risk for private sector balance sheets could be significant. Staff noted that in the event of high pressures, the BCP should bolster its lender of last resort capabilities through international support, if needed. To moderate the pressures on the exchange rate, the authorities tightened the regulations on net foreign assets positions, reducing the limit for long positions from 50 percent to 30 percent of capital, and introducing a limit of US\$1 million for the change in the daily position.

\section{In response, the authorities indicated that they are strengthening the policy} framework to respond to financial stress. They identified the main vulnerabilities to the financial sector as stemming from liquidity concerns, the high level of dollarization, the drying-up of external credit lines, and a deterioration of credit quality. The liquidity framework has been improved through the introduction in October 2008 of a short-term facility providing liquidity at a penalty rate (FLIR). ${ }^{14}$ In addition, the Central Bank reduced reserve requirements to provide additional liquidity to the system. ${ }^{15}$ The bank resolution framework is being strengthened, while the Superintendency of Banks has stepped up monitoring of the institutions under most financial strain, including by establishing recently a Financial Stability Department to monitor the effects of the global financial crisis. The authorities are also discussing with banks the capitalization of part of the exceptionally strong profits generated in 2008 to enhance the capital buffer of the system.

20. Medium-term financial policies. While significant efforts have been made in improving the resilience of the financial system to withstand periods of distress, and in developing capital markets, more needs to be done to have modern institutions and frameworks in place (Appendix 2). In particular, there is a need to recapitalize the Central

\footnotetext{
${ }^{14}$ To date, no financial institution has used the facility, out of concern for a negative signaling effect. The penalty rate is 10.5 percent.

${ }^{15}$ By $4 \frac{1}{2}$ percentage points on foreign-currency denominated deposits and by 2 percentage points on domestic currency-denominate deposits in November 2008. In February 2009, reserve requirements on FX term deposits of 361-540 days were reduced to 16.5 percent, and those on deposits of over 540 days were reduced to zero as were those on domestic currency deposits of over 360 days.
} 
Bank, strengthen the regulatory framework for commercial banks and establishing a comprehensive regulatory supervisory framework for cooperatives. ${ }^{16}$

- Central Bank. The cost of bank bailouts during previous financial crises led to the BCP's capital becoming negative, impairing its capacity to conduct policy and function properly. It is estimated that the BCP has a capital shortfall of about 6 percent of GDP. The government expected to send, by end-2009, legislation to Congress to allow for a recapitalization through a transfer of marketable treasury bonds that might, in the medium term, replace LRMs.

- $\quad$ Commercial banks. In April 2007, the authorities developed a comprehensive strategy to improve governance rules, enhance the independence of the Superintendency of Banks, strengthen "fit and proper" criteria, and strengthen capital requirements. The authorities have been implementing the strategy, a key component of which was the implementation of Resolución $1^{17}$ in October 2008 - on assets classification and provisioning requirements. However, significant shortcomings remain in order to increase the compliance with Basel Core Principles of Effective Banking Supervision. In particular, the Banking Law and Central Bank Law need to be amended to: (i) improve governance rules; (ii) enhance the independence and sanctioning capacity of the Superintendency of Banks (SB); (iii) further strengthen "fit and proper" criteria; and (iv) strengthen capital requirements.

\footnotetext{
${ }^{16}$ Other financial intermediaries that are in need of strengthened regulatory and supervisory frameworks are insurance companies and pension funds, which according to some estimates account for about 10 percent of financial system assets (of approximately 50 percent of GDP).

${ }^{17}$ Which replaced Resolución 8 of 2003.
} 


\section{Box 4. Paraguay: Lessons from Previous Banking Crises, 1995-2003}

Paraguay experienced five financial crises during an eight-year period from the mid-1990s. These episodes illustrate what and what not to do when confronted with banking crisis. While the response was generally inadequate in the first three crises, the authorities, notably the Superintendency of Banks (SBP), responded appropriately and in a timely manner to the 2002 and 2003 crises. The authorities' learning experience is evidenced by cost of the crises, which amounted to only 1 percent of GDP in the last two episodes against 15 percent for the earlier crises.

Table: Banking Crises in Paraguay-Causes, Magnitude, and Policy Response

\begin{tabular}{|c|c|c|c|}
\hline Date & Cause of the Crisis & Bank(s) Affected & Policy Response \\
\hline 1995 & $\begin{array}{l}\text { It was the byproduct of a rapid financial } \\
\text { liberalization without adequate } \\
\text { safeguards in terms of sound prudential } \\
\text { regulations and enforcement. The crisis } \\
\text { was triggered when two large banks } \\
\text { failed to meet their clearing obligations. }\end{array}$ & $\begin{array}{l}\text { Second and third } \\
\text { largest banks with } \\
16 \text { percent of } \\
\text { deposits. }\end{array}$ & $\begin{array}{l}\text { The authorities decided to honor } \\
\text { deposits in the intervened banks, } \\
\text { without imposing sanctions on the } \\
\text { banks that did not improve their } \\
\text { performance. }\end{array}$ \\
\hline 1997 & $\begin{array}{l}\text { The crisis occurred principally due to the } \\
\text { authorities' inadequate response to the } \\
\text { first crisis, as regulatory forbearance and } \\
\text { generous de facto deposit guarantees } \\
\text { allowed financial institutions and } \\
\text { depositors to continue with the status } \\
\text { quo without paying adequate attention to } \\
\text { risk. The first private bank was eventually } \\
\text { intervened. }\end{array}$ & $\begin{array}{l}\text { First bank with } \\
7 \text { percent of deposits. } \\
\text { Some financieras } \\
\text { were also affected. }\end{array}$ & $\begin{array}{l}\text { The authorities closed two banks. } \\
\text { Despite the SIB increased reluctance } \\
\text { to provide support, the coverage of } \\
\text { deposit insurance was increased while } \\
\text { regulatory forbearance, accounting } \\
\text { flexibility and transfer of public sector } \\
\text { deposits to weak banks allowed them } \\
\text { to survive. }\end{array}$ \\
\hline 1998 & $\begin{array}{l}\text { The financial situation of the fourth } \\
\text { largest bank deteriorated and its liquidity } \\
\text { dried up while depending increasingly on } \\
\text { public sector deposits. }\end{array}$ & $\begin{array}{l}\text { Fourth largest bank } \\
\text { with } 6 \text { percent of } \\
\text { deposits. Some } \\
\text { financieras affected. }\end{array}$ & $\begin{array}{l}\text { The bank was closed and the SIB } \\
\text { encouraged the merger and } \\
\text { recapitalization of the banking system. }\end{array}$ \\
\hline 2002 & $\begin{array}{l}\text { The deposit freeze in Argentina led to a } \\
\text { bank run on its local subsidiary. }\end{array}$ & $\begin{array}{l}\text { Third bank with } \\
11 \text { percent of } \\
\text { deposits. }\end{array}$ & The bank was closed. \\
\hline 2003 & $\begin{array}{l}\text { It was mainly a result of fraud in a } \\
\text { medium-size locally owned bank. }\end{array}$ & $\begin{array}{l}\text { 8th largest bank with } \\
5 \text { percent of deposits. }\end{array}$ & The bank was closed. \\
\hline
\end{tabular}

Among the lessons that can be drawn from the crises:

- An effective banking resolution strategy needs to identify which banks are solvent or insolvent. Supporting fundamentally insolvent institutions is unlikely to succeed, and even more so if inefficient bank owners continue running their banks.

- Generous de facto deposit guarantees distort incentives and encourage excessive risk-taking over time. Guarantees should be limited and accompanied by an effective restructuring plan and otherwise remove the pressure from the authorities to rapidly resolve the underlying banking problems.

- Defining responsibility. Who bears the ultimate cost, i.e. the Treasury, needs to be clarified upfront in order to avoid burdening the central bank balance sheet with non-performing assets.

- Private sector lending takes a long time to recover, even if other indicators of bank behavior like profitability typically recover easily after crises. This is true even from a regional (Mercosur) perspective. ${ }^{1}$

Source: Mlachila, 2009 (forthcoming), "Recurrent Financial Crises: Causes, Costs, and Consequences".

${ }^{1}$ For a detailed analysis, see Mlachila, 2009, "Post-Crisis Behavior of Banks in Mercosur", Selective Issues Paper. 


\section{Medium-Term Policies to Sustain Growth and Reduce Poverty}

21. Structural reform agenda. The key medium-term policy challenge facing the authorities is to return to and sustain the high real growth rates of the past five years, while further reducing poverty. Discussions focused on creating room in the budget to meet additional social and infrastructure expenditure needs, strengthening the budgetary framework, sustaining growth and boosting competitiveness, and on measures aimed at directly reducing poverty.

22. Fiscal and budgetary measures. Paraguay has one of the lowest tax revenue-to-GDP ratios in Latin America. Staff estimates that with a combination of tax policy changes and administrative improvements, the tax ratio could be increased significantly over the medium term. There are significant weaknesses in the budgetary processes, notably Congress' virtually unlimited powers to change the entire budget. At the same time, the quality and structure of public expenditures needs to be improved. Specifically, there is need to curb the rapid growth of wages and salaries and increase infrastructure spending.

- Tax reforms. While considerable progress has been achieved since 2004, additional reforms are needed to expand the tax base. The authorities eliminated the use of VAT credits against the tax on agricultural income (IMAGRO), which will impose a fairer burden on agriculture (the main economic activity in Paraguay) in the medium-term. ${ }^{18}$ In addition, the personal income tax (PIT)

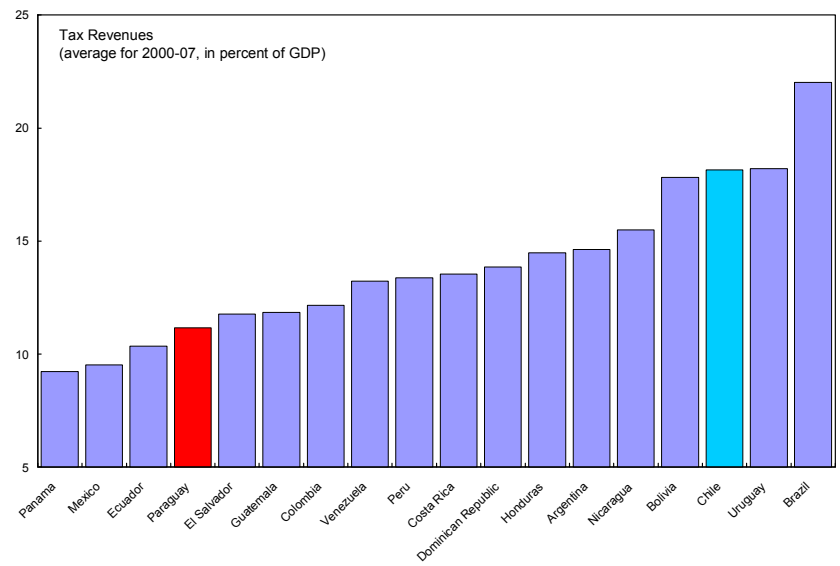
became effective from January 1, 2009, although its yield will be substantially affected by extensive exemptions and deductions, and the lack of withholding mechanisms. ${ }^{19}$ Other tax policy recommendations are to (i) limit the use of reduced VAT rates and exemptions; (ii) lower the number of products subject to the excise tax but at higher rates; and (iii) rationalize the special regime for small taxpayers. Regarding tax and customs administration, staff suggested the following measures: (i) submitting to Congress the new tax procedures code; (ii) enhancing audit capacity on taxpayers; (iii) improving customs control; (iv) establishing HR policies for tax

\footnotetext{
${ }^{18}$ The current stock of VAT credits can be used to continue offsetting IMAGRO revenues. Given the size of the stock (around US\$250 million), the IMAGRO revenues are estimated to pick up only by 2011.

${ }^{19}$ Congress recently approved a draft law to postpone once again the PIT implementation.
} 
and customs administrations; and (v) implementing a comprehensive management system in tax and customs administration.

- $\quad$ Expenditure reforms. Public expenditure management and control need to be improved to increase accountability and reduce the already high fiscal rigidities. Priority areas on public financial management (PFM) and budgetary framework include: (i) consolidating all accounts into the "Single Treasury Account"; and (ii) strengthening the medium-term expenditure framework to better integrate it with the annual budget cycle. ${ }^{20}$ A major challenge is the need to limit Congress' ability to modify the budget envelope, particularly salaries. In addition, the government should work on a comprehensive pension system reform that ensures financial sustainability and improves efficiency and coverage.

- $\quad$ Budget execution. Staff recommended renewed efforts in increasing the execution rate of the budget, especially capital expenditures, a key component of the authorities' plan. In reply, the authorities noted that they have intensified training in line ministries to increase implementation capacity. Staff also stated the importance of adopting a comprehensive

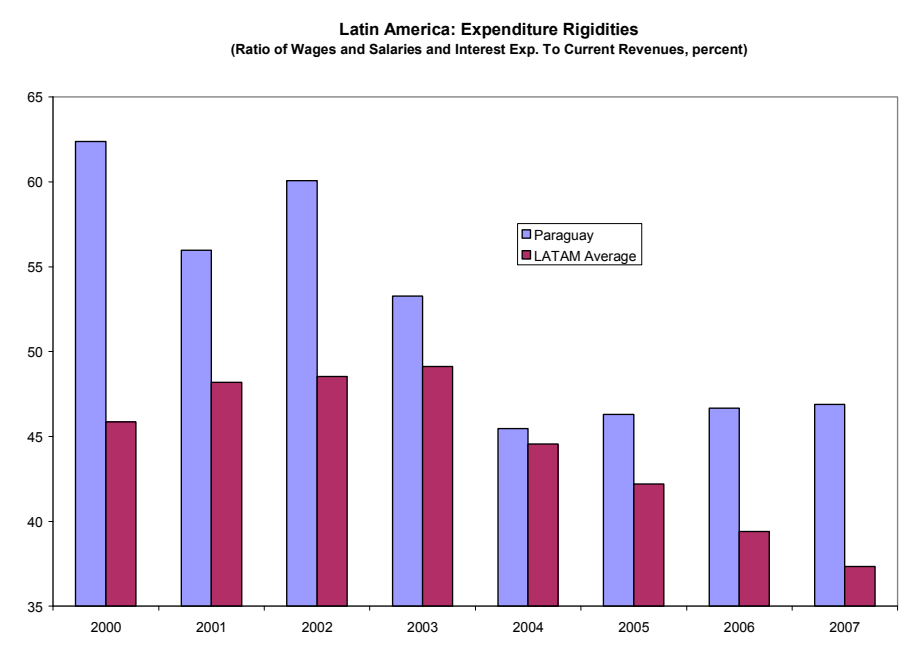
public investment system in order to enhance efficiency and accountability of the capital budget execution.

23. Enhancing Growth. The focus should be on reforms that could increase Paraguay's growth potential. While in recent years considerable progress has been achieved in improving the business climate, ${ }^{21}$ lasting improvements in the operations of the state-owned enterprises (SOEs) proved elusive. Important reforms that could boost growth include: (i) a fundamental restructuring of SOEs; (ii) a significant upgrade of infrastructure, especially in electricity, telecommunications, and roads; and (iii) a strong effort to promote FDI.

- SOE Enhanced Accountability and Restructuring. Reforms of SOEs should build on the progress realized by the Consejo Supervisor de las Empresas del Estado (CSEE)

\footnotetext{
${ }^{20}$ For instance, to include recurrent costs of any investment.

${ }^{21}$ For instance, increasing the ease of starting a business and the creation of a one-stop export window.
} 
and draw the lessons from its shortcomings. In particular, the establishment of an information system with scorecard methodology — which increased transparencywas a notable achievement, though it fell short on the provision of reliable financial data. However, performance of SOEs has not improved. Going forward, staff and authorities agreed that the focus of reforms should be on: (i) establishing a proper incentive and sanctioning system; (ii) adopting comprehensive strategic and business plans for all SOEs, linked to a realistic performance management monitoring; and (iii) encouraging increased participation of the private sector, such as PPP mechanisms. Additional efforts will need to be deployed in improving two poorly performing companies-INC (cement production) and Petropar (oil products).

- Infrastructure. Paraguay's economic infrastructure needs considerable upgrades in at least three areas: electricity, telecommunications, and roads. In the electricity sector, it is unfortunate that Paraguay, with abundant hydro-electricity, faces power cuts and lack of capacity for new business projects. There is a serious need to upgrade transmission and distribution of electricity. Regarding communications, COPACO's monopoly in telephone landlines and internet connectivity has led to inefficient service at high unit costs. Liberalization of the sector, which is quite profitable, would undoubtedly bring in private capital and improve the quality of services to the public. The expansion of the feeder road network would improve market access and raise incomes of rural communities.

- FDI Promotion. FDI inflows have been relatively limited in Paraguay, compared to other economies in the region. The country could capitalize on its advantages, such as relatively cheap real estate and energy, to make more determined efforts to attract FDI. Despite a very low corporate income tax rate (10 percent), key impediments have been: weak infrastructure, widespread informality, and perceived low transparency in the judiciary process, particularly with regard to the respect and enforceability of contracts.

24. Social Investment. Growth alone will not be sufficient to reduce poverty meaningfully. There is need for renewed efforts in addressing shortcomings in health and education. In the short run, direct efforts to combat extreme poverty are required. Developments of the past five years show that although growth has helped reduce the overall level of poverty, extreme poverty rose from $15^{1} \frac{1}{2}$ percent in 2005 to $19^{1} / 2$ percent in 2007 , mostly due to rising food prices. Staff recommended the significant scaling up to the CCT program. The program has been quite successful, and has led to a meaningful improvement on several poverty indicators among the covered population. ${ }^{22}$ In order to institutionalize and safeguard the program, it would also be useful to adopt appropriate legislation in this regard.

\footnotetext{
${ }^{22}$ For an overview and assessment of the CCT program, see, Box 3, IMF Country Report 08/268.
} 
The authorities agreed with staff's recommendations and indicated that their medium-term coverage target is 120,000 households (about $2 / 3$ of the extremely poor). They also intend to embark on the construction of low-income housing, and land reform.

\section{StafF ApPraisal}

25. Overall. Paraguay is well placed to confront the global financial turbulence and economic recession, in large part due to the prudent macroeconomic policies pursued in recent years. Continued fiscal surpluses, which led to a considerable decline the public debt burden, provide the government with sufficient margin to conduct counter-cyclical policies until a global economic recovery takes hold. With an appropriately designed an implemented recovery plan, Paraguay has the capacity to weather the current crisis, supporting economic activity in the immediate future, addressing social needs, while setting the basis for a return to sustained and broad-based growth.

26. Fiscal policy. The government's plan to support the economy through fiscal stimulus measures appropriately focuses on public investment and effective social programs to mitigate poverty, financed by external official resources. To achieve the desired impact, it will be important to improve public financial management and inter-ministerial coordination so as to ensure the plan's timely and effective implementation, especially of the public investment program. In addition, tax and customs administrations need further improvement to prevent a deterioration in compliance levels and avoid undesired revenue falls. Finally, setting the recovery program in a medium-term context would help articulate priorities better, encompassing an appropriate mix of short-term temporary measures with immediate impact on employment and growth, and medium-term sustainable programs to develop much-needed infrastructure and advance the social agenda.

27. Monetary policy. In part as a result of the weakening import prices, inflation is now on a firmly downward trend, well within the Central Bank's target range. Improved fundamentals have led to renewed confidence in the guarani and the authorities have so far reacted appropriately to the adverse economic conditions. Monetary policy has been eased, and the central bank has injected liquidity into the financial system by retiring sterilization bills. Close monitoring of developments is key, and the authorities will need to respond promptly to signs of inflationary or balance of payments pressures.

28. Exchange rate and external policies. Exchange rate flexibility continues to serve Paraguay well by acting as a shock absorber in the face of commodity price fluctuations and strong regional linkages. Staff analysis indicates that as of end-2008, the exchange rate was broadly in line with fundamentals. While the banking system remains relatively wellsheltered from global turbulences, a tightening of external financing is to be expected. Hence, the proposed external financing from international financial institutions to cover the fiscal stimulus would provide much-needed relief. 
29. Financial sector. The banking system is solid and staff welcomes recent improvements of prudential regulations, which should not be diluted. Efforts are required to improve incentives for medium-term savings, since the lack of long-term domestic funding constrains banks' capacity to meet the private sector's financing needs, while avoiding directed credit schemes that would only erode confidence. In addition, measures to strengthen regulation and supervision of cooperatives, insurance and retirement plans are urgently needed, given the large amounts of funds intermediated by these sectors, and the risks of contagion stemming from any perceived weaknesses.

30. Structural Reforms. Staff urges the authorities to continue to make progress in all areas of the reform agenda. A particular priority is to implement a strategy to strengthen the central bank balance sheet, since its chronic negative net worth could weaken monetary policy. Administrative steps have been taken to improve supervision and launch muchneeded reforms of SOEs, but these need to be accompanied by decisive actions to enhance their efficiency and make them financially viable, removing important bottlenecks in the productive capacity of the economy. Finally, efforts to improve the business environment need to be sustained, especially in the area of contract enforceability.

31. Risks. On the external front, exports would suffer if commodity prices remain depressed and export demand falls - particularly in the wake of a slowdown in trading partners affected by tightening credit conditions. Remittances will also be negatively affected, and foreign direct investment and financing are likely to be lower in 2009-10. Maintaining a strong reserve position is needed to bolster confidence, especially in view of the high dollarization of the banking system. On the domestic front, the main risks would stem from a slow implementation of the recovery plan, which could blunt is effectiveness as an anti-cyclical tool and erode support for reforms, or the emergence of financial weaknesses in a cooperative or small bank that might threaten contagion. On the political front, the fragmentation in Congress might thwart the government's ability to adopt effective anti-crisis measures and implement its reform agenda. Pressures from interest groups may also emerge to backtrack on recent reforms or to increase spending on distortionary or non-sustainable measures that would undermine macroeconomic stability.

32. Consultation. The staff proposes that the next Article IV Consultation take place within the 12-month cycle. 
Figure 1. Paraguay: Real Sector Developments

After a strong acceleration of growth in 2007 and early 2008, supported by two record years of agricultural production, GDP started to decline sharply. The unwinding of supply shocks, which had had a spillover effect into core inflation until mid-2008, contributed to the decline of core inflation.

Real GDP growth was solid in 2008...

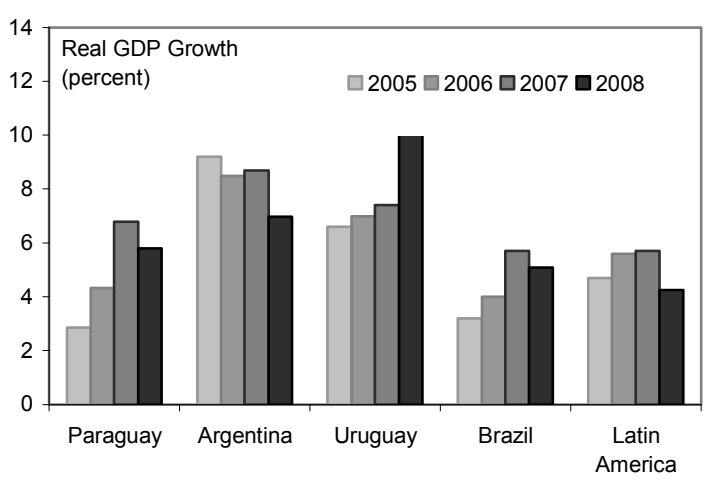

However, growth has decelerated sharply in 2008Q3

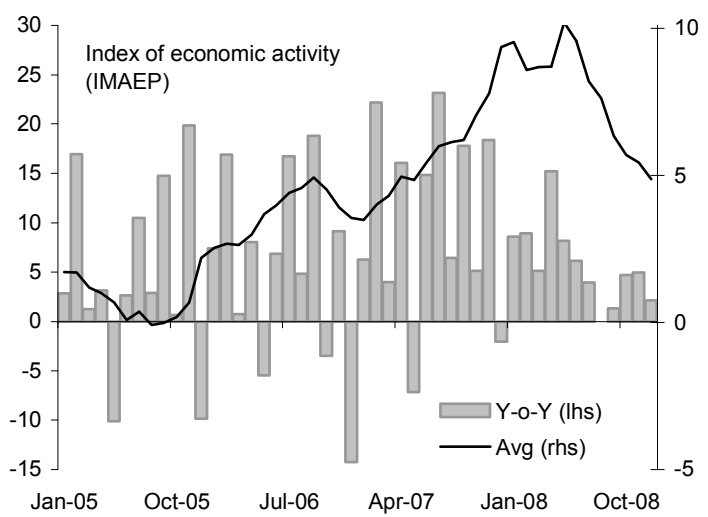

Energy and food supply shocks have reversed, like elsewhere in the region...

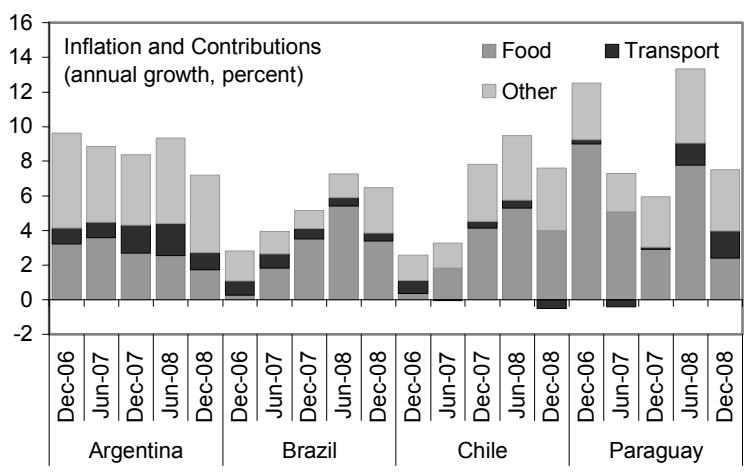

Source: Paraguayan Authorities and Fund staff estimates. ...and broad based.

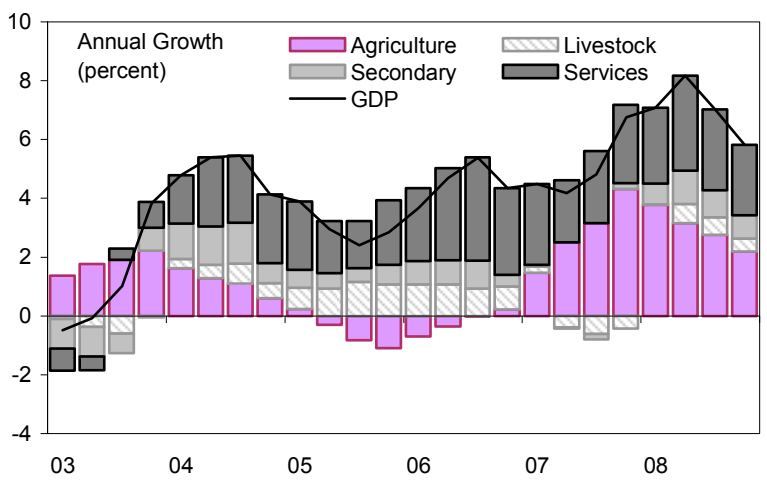

...as evidenced, for example, by the decline of primary export volumes.

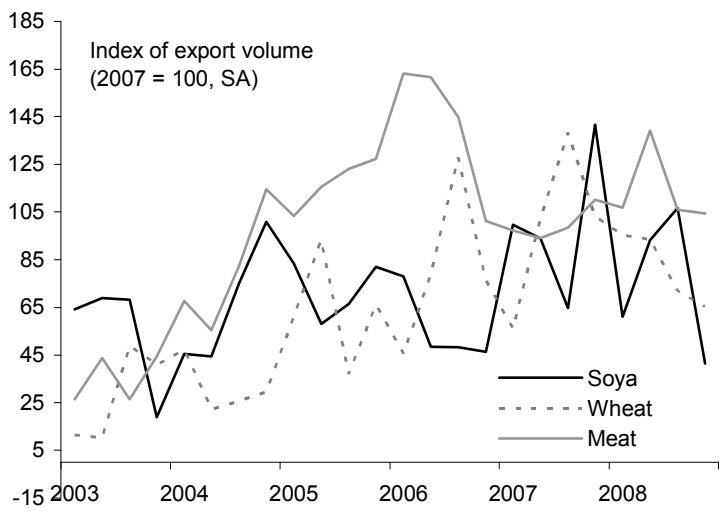

...driving down inflation despite possible pressures from the depreciation of the currency.

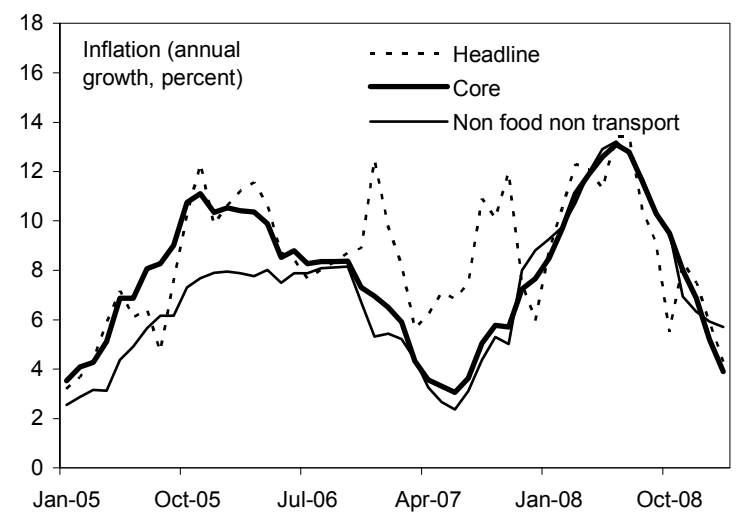


Figure 2. Paraguay: Fiscal Developments

Significant progress has been made in reducing fiscal imbalances in line with general regional trends, although Paraguay has performed better than its MERCOSUR partners.

Paraguay has one of the strongest fiscal positions in the region...

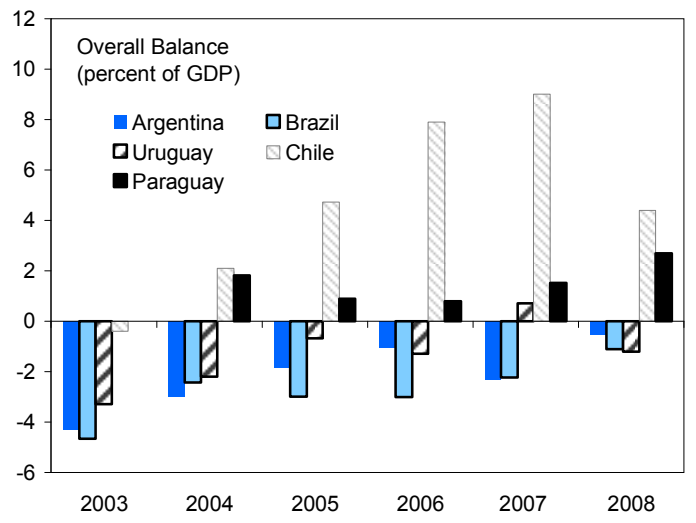

This has been achieved through improved revenue...

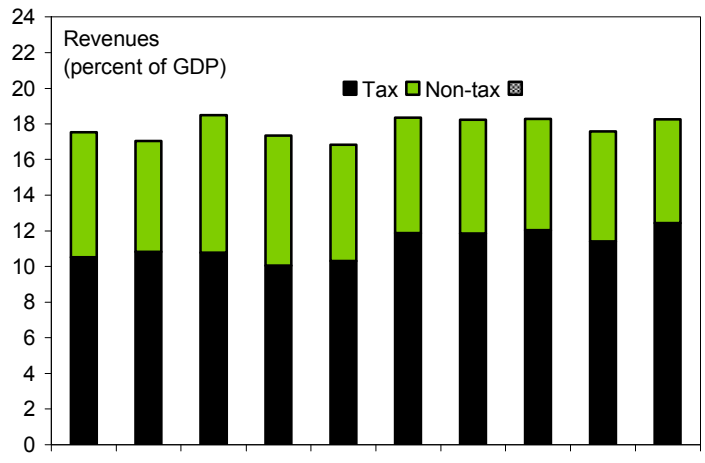

1999200020012002200320042005200620072008 1/ As of September 2007.

Fiscal policy has been quite counter-cyclical with good tax revenue performance and well-contained current expenditures...

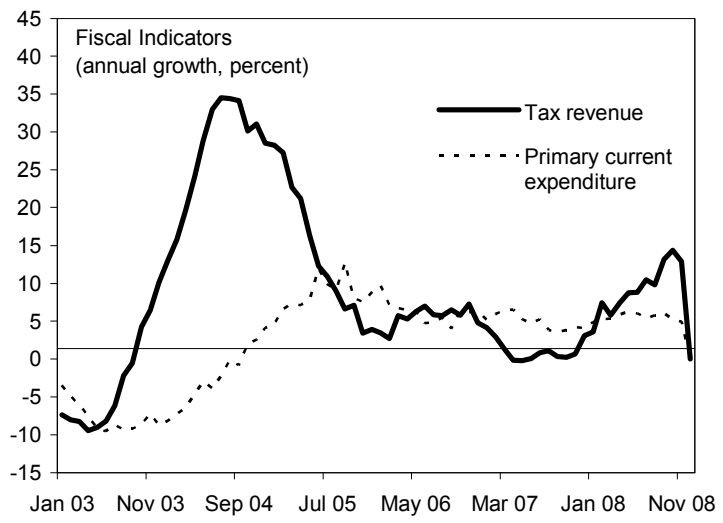

... and one of the lowest levels of public debt in the region.

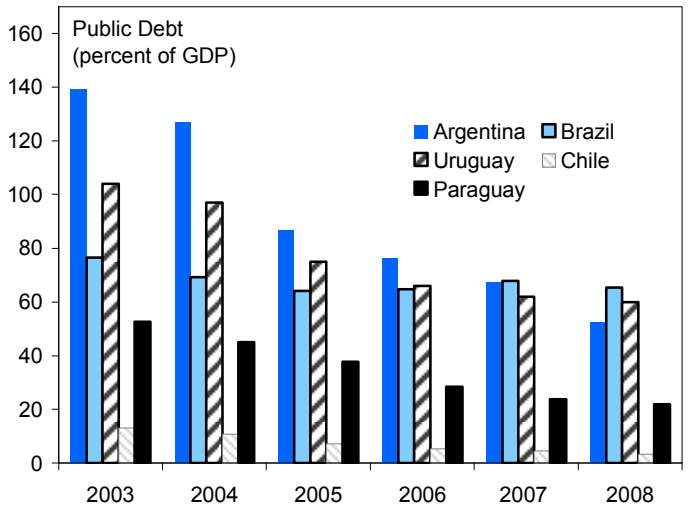

...and by efforts to contain current spending.

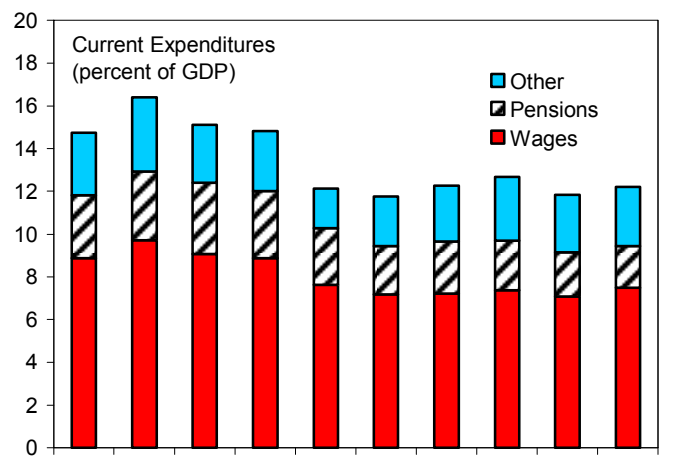

1999200020012002200320042005200620072008

...but unfortunately capital expenditures were heavily underexecuted this year.

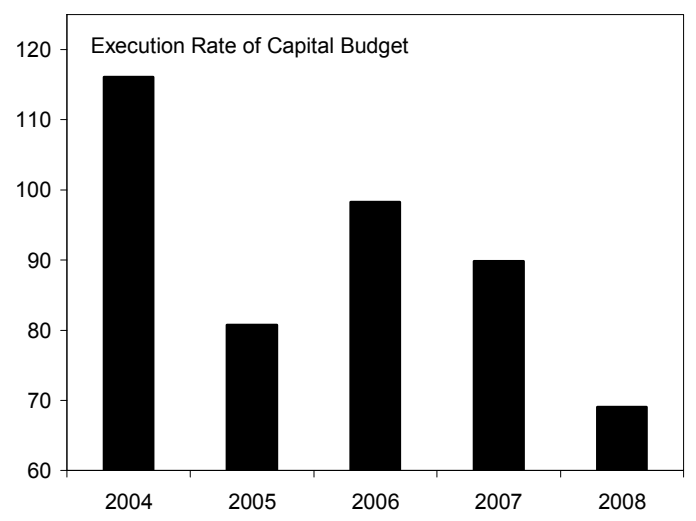


Figure 3. Paraguay: Monetary Developments

Currency and credit to the economy continued to grow at a very high speed until the third quarter. In October, the central bank and commercial banks adjusted to the changing economic environment. Monetary authorities took a number of measures to provide sufficient liquidity to the financial system.

Foreign inflows, which have been fueling a high level of currency growth, started to revert as early as July...

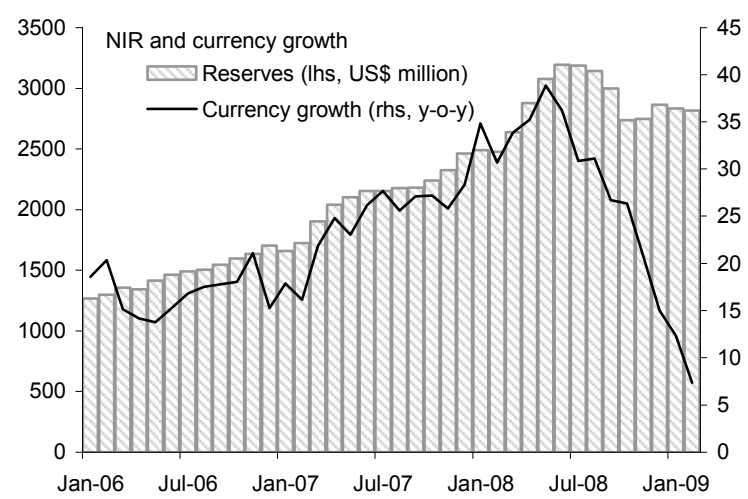

Similarly, despite the early decline of deposits, banks continued to increase lending at the same pace until October...

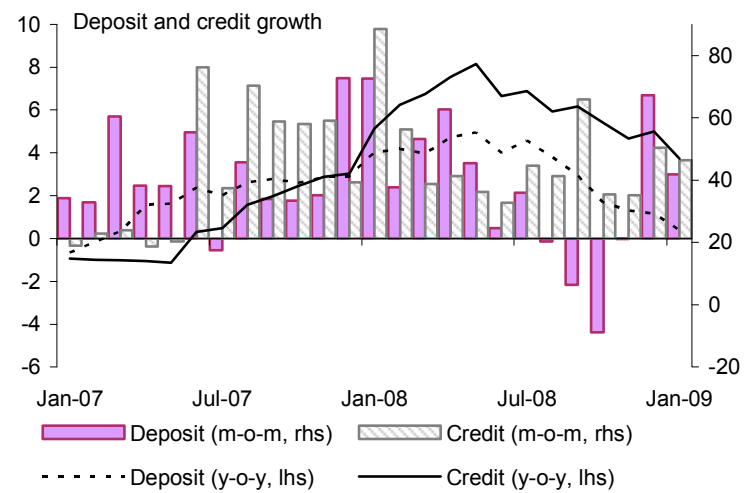

As financial constraints became binding, the central bank reduced reserve requirements and decreased its policy rate while banks raised deposit and lending rates.

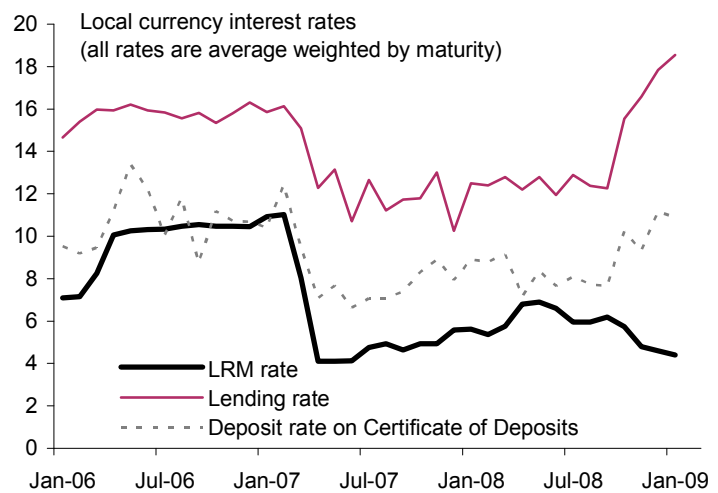

Source: Paraguayan Authorities and Fund staff estimates. ...but monetary authorities attempted to resist downward pressures on the exchange rate until October.

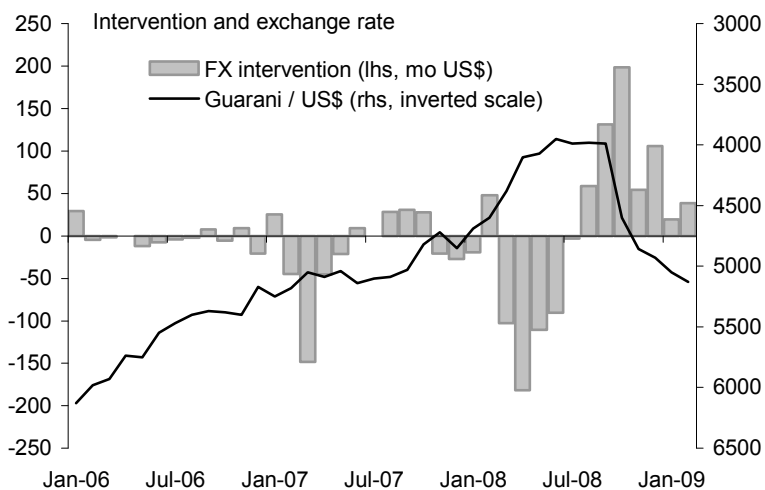

...reallocating their asset away from sterilization paper (LRM) and using free reserves at the central bank.

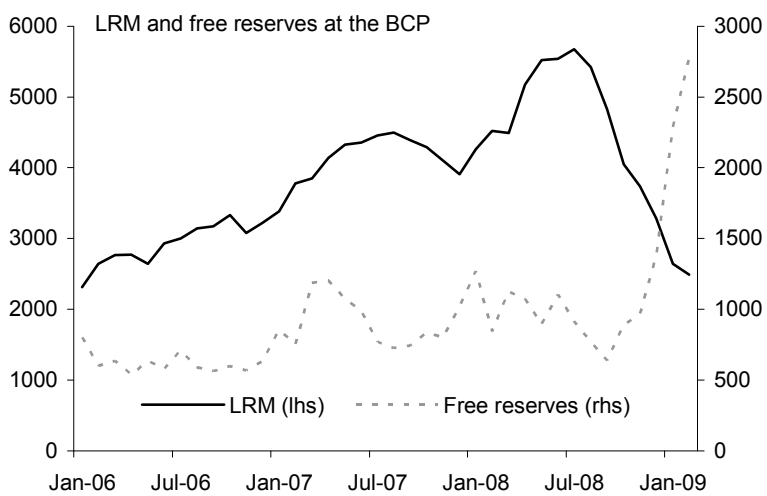

The inflation and the $L R M$ rate went up in response to external shocks in 2007 but have come down as the shock effects dissipated.

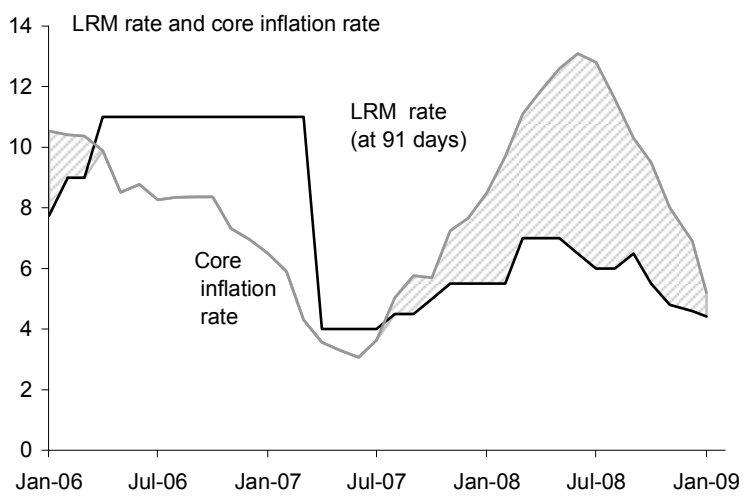


Figure 4. Paraguay: Financial System Developments

While financial markets are the least developed in the region, they continued expanding and strengthening as macroeconomic conditions continued to improve.

Market capitalization is low in Paraguay but capital markets are ripe for development.

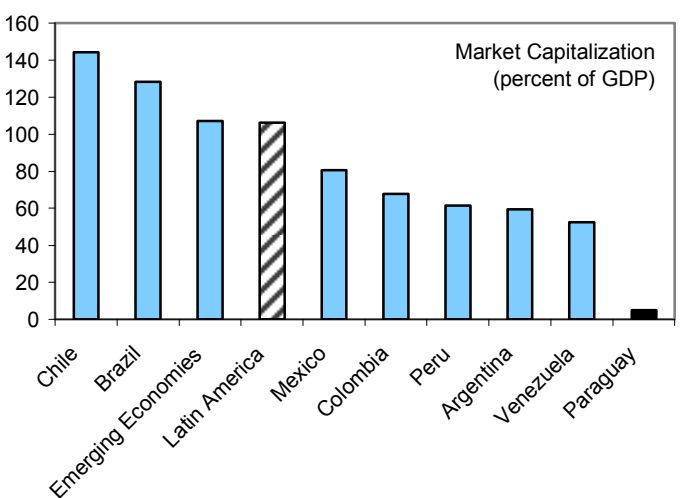

... at the same time, dollarization continues to decline...

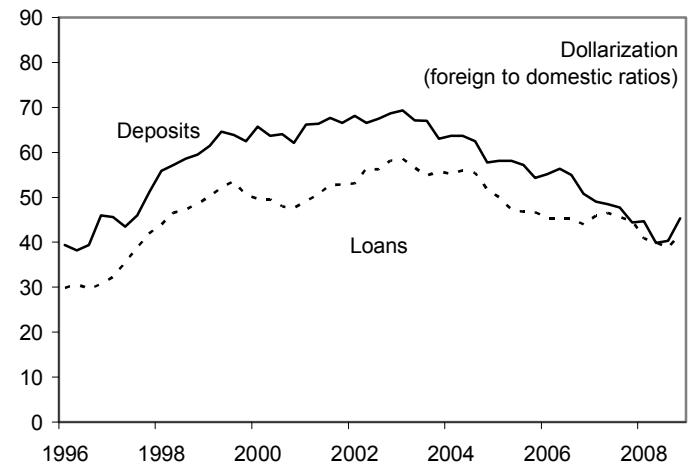

Loans continue to perform well, contributing to declining financial deliquency and increased profitability....

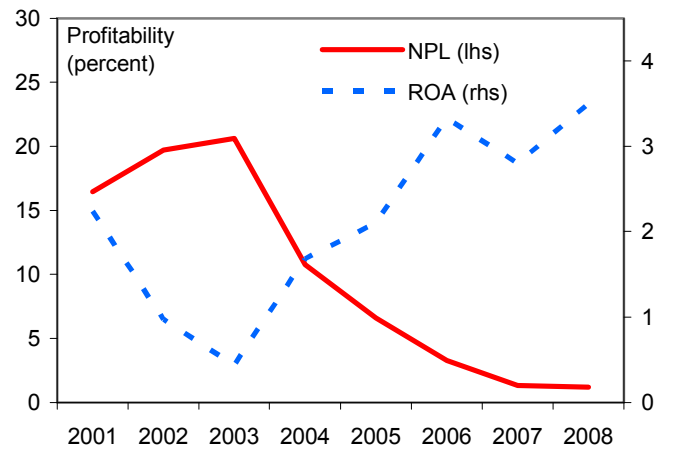

Credit to the private sector is beginning to recover increasing financial deepening..

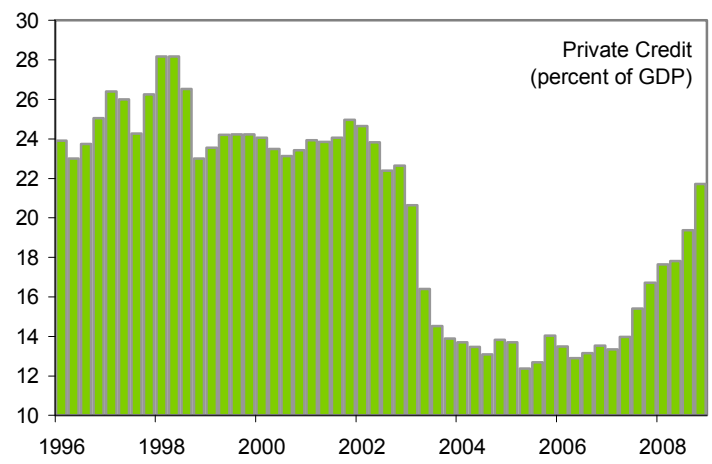

... and the maturity of assets and liabilities has lengthened...

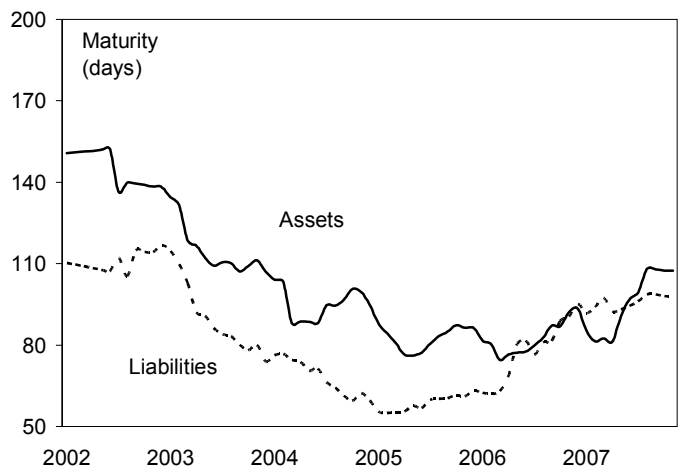

... as a result, the system remains well-capitalized, with CARs well above the 10 percent regulatory minimum.

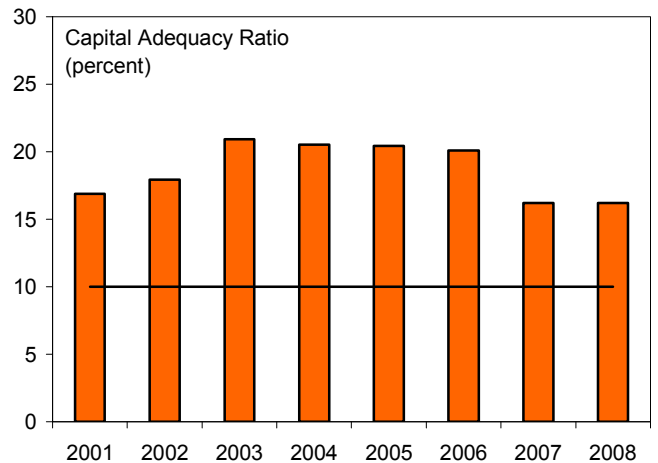

Sources: Paraguayan Authorities and Fund staff estimates. 
Figure 5. Paraguay: Balance of Payments Developments

The external position weakened somewhat in 2008, largely on account of surging fuel prices, and a slowdown in regional trade partners.

Paraguay's external current account recorded a deficit in 2008 on account of high fuel prices...

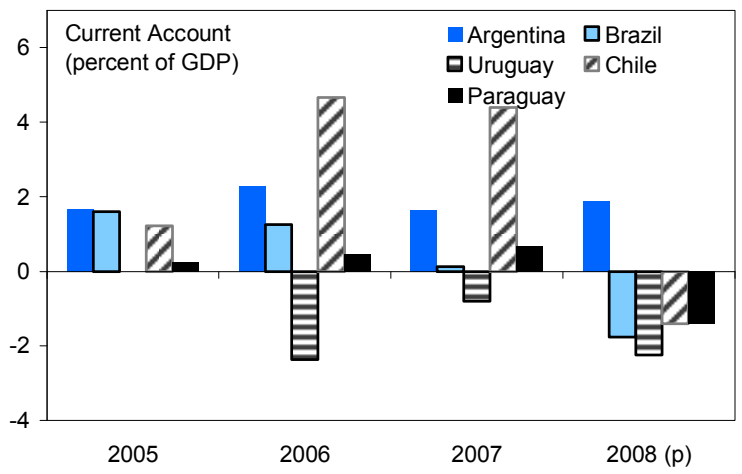

Surging soy exports prices contributed to the strong export performance through $2007 .$.

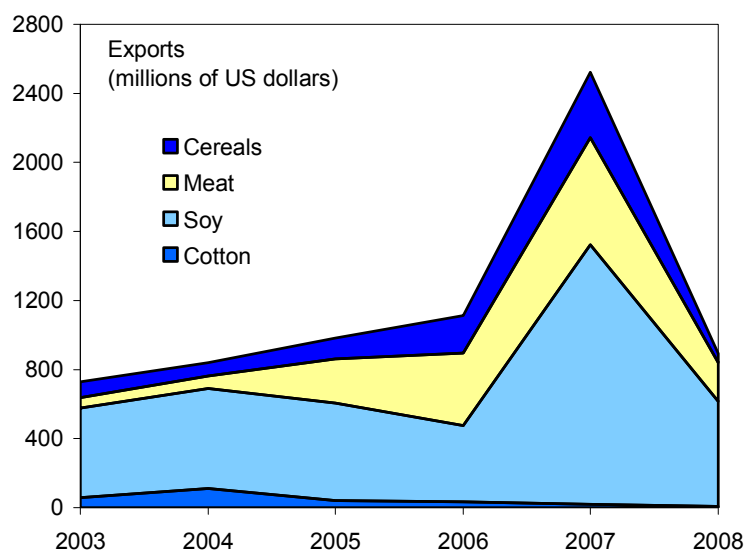

....and continued large flows of the hydroelectric binational entitites, leading to increased NIR...

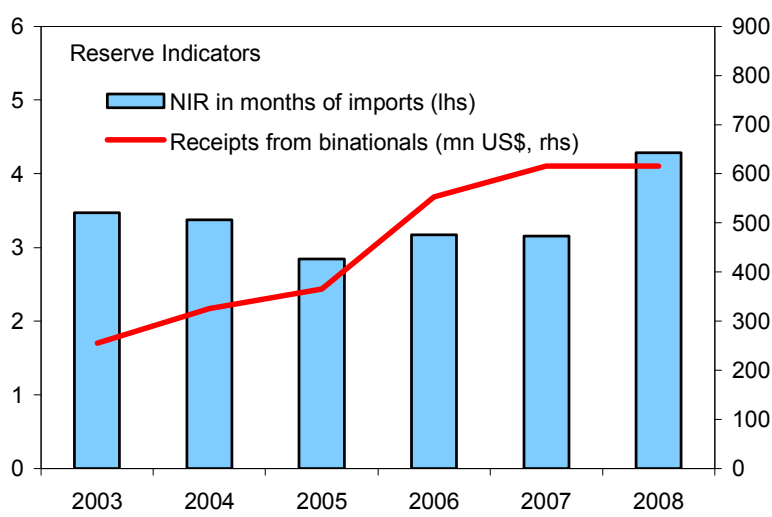

... while the appreciation against the US dollar has been strong in 2007 and 2008 compared to most countries in the region.

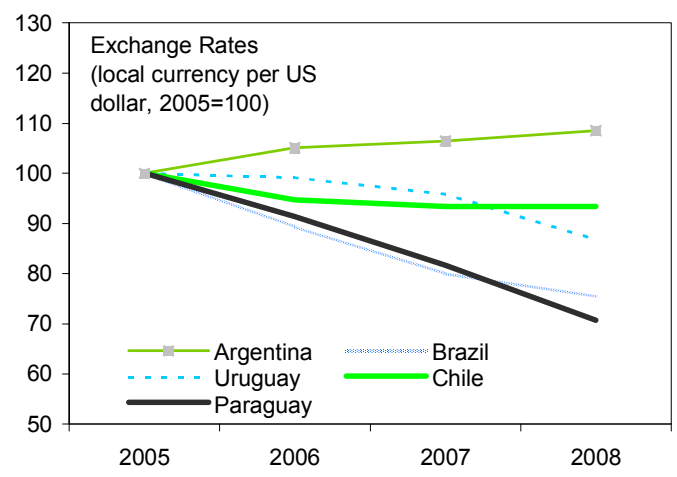

... while the growth in imports contriubted to a widening of the trade balance.

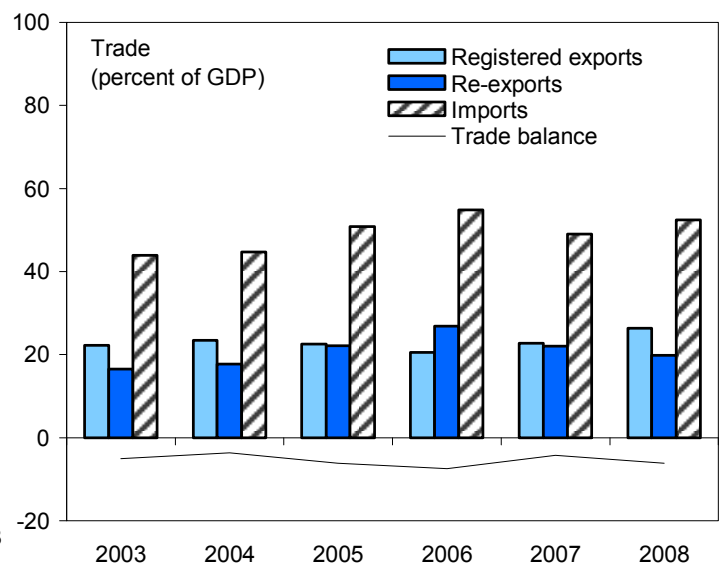

... assisted by a depreciaiton of the real effective exchange rate.

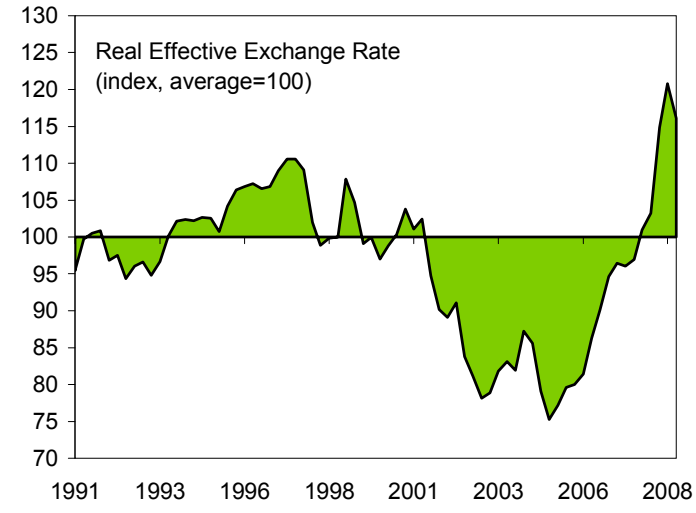

Sources: Paraguayan Authorities and Fund staff estimates. 
Table 1. Paraguay: Selected Economic and Social Indicators

\begin{tabular}{|c|c|c|c|}
\hline \multicolumn{4}{|c|}{ I. Social and Demographic Indicators } \\
\hline \multirow[t]{2}{*}{ Area (thousand sq. km) } & \multicolumn{3}{|c|}{407 Income distribution (2002) } \\
\hline & & \multicolumn{2}{|l|}{ By highest 20 percent of households (percent) } \\
\hline \multicolumn{2}{|l|}{ Population (2005) } & \multicolumn{2}{|l|}{ By lowest 20 percent of households (percent) } \\
\hline Total (in millions) & \multicolumn{3}{|c|}{ 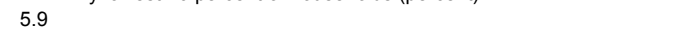 } \\
\hline Rate of increase (percent a year) & \multicolumn{3}{|c|}{1.9 Health $(2004)$} \\
\hline Density (per sq. km.) & 14.5 & Physicians per 1,000 people & 1.1 \\
\hline \multirow{2}{*}{ Unemployment (2007) } & \multirow[t]{2}{*}{5.6} & Hospital beds per 1,000 people & 1.3 \\
\hline & & Access to a water source (percent) & 80 \\
\hline \multicolumn{2}{|l|}{ Population characteristics (2004) } & Access to a sanitation facility (percent) & \multirow[t]{2}{*}{86} \\
\hline Life expectancy at birth (years - 2005) & \multirow{2}{*}{\multicolumn{2}{|c|}{$\begin{array}{l}71.4 \\
29.7 \text { Education (2004: in percent) }\end{array}$}} & \\
\hline Crude birth rate (per thousand) & & & \\
\hline Crude death rate (per thousand) & \multicolumn{2}{|c|}{ 5.0 Male literacy rate (percent) } & 94 \\
\hline \multirow[t]{3}{*}{ Infant mortality (per thousand live births) } & \multirow[t]{3}{*}{21.0} & Female literacy rate (percent) & 92 \\
\hline & & Primary school enrollment (net, percent) & 94 \\
\hline & & Secondary school enrollment (gross, percent) & 63 \\
\hline
\end{tabular}

II. Economic Indicators, 2004-2009

\begin{tabular}{|c|c|c|c|c|c|c|}
\hline & 2004 & 2005 & 2006 & 2007 & $\begin{array}{r}\text { Est. } \\
2008\end{array}$ & $\begin{array}{l}\text { Proj. } \\
2009\end{array}$ \\
\hline \multicolumn{7}{|c|}{ Annual percent change; unless otherwise specified } \\
\hline \multicolumn{7}{|l|}{ National accounts and prices } \\
\hline GDP at current prices & 16.4 & 11.2 & 13.2 & 17.7 & 13.3 & 7.4 \\
\hline GDP at constant prices & 4.1 & 2.9 & 4.3 & 6.8 & 5.8 & 0.5 \\
\hline Per capita GDP (U.S. dollars, thousands) & 1.2 & 1.3 & 1.6 & 2.0 & 2.6 & 2.4 \\
\hline GDP deflator & 11.8 & 8.1 & 8.5 & 10.2 & 7.1 & 6.8 \\
\hline Consumer prices (end-of-period) & 2.8 & 9.8 & 12.5 & 5.9 & 7.5 & 5.5 \\
\hline \multicolumn{7}{|l|}{ Real effective exchange rate $1 /$} \\
\hline Average (depreciation -) & 3.7 & -6.5 & 13.0 & 10.8 & 16.4 & $\ldots$ \\
\hline End-of-period (depreciation -) & -8.6 & 4.4 & 20.1 & 5.5 & 9.6 & $\cdots$ \\
\hline \multicolumn{7}{|c|}{ In millions of U.S. dollars } \\
\hline \multicolumn{7}{|l|}{ External sector } \\
\hline Exports, f.o.b. (percentage change) & 32.0 & 17.4 & 31.2 & 24.4 & 42.0 & -13.3 \\
\hline Imports, c.i.f. (percentage change) & 27.0 & 22.9 & 33.7 & 17.6 & 46.9 & -14.9 \\
\hline Net oil exports and imports & -434 & -507 & -701 & -723 & $-1,308$ & -596 \\
\hline Current account & 143 & 19 & 45 & 82 & -227 & -153 \\
\hline (in percent of GDP) & 2.1 & 0.3 & 0.5 & 0.7 & -1.4 & -1.0 \\
\hline Capital account & 41 & 397 & 356 & 362 & 399 & 152 \\
\hline Overall balance & 277 & 147 & 402 & 762 & 321 & 0 \\
\hline Terms of trade (percentage change) & -1.4 & -9.9 & -2.3 & 6.2 & -1.1 & -5.1 \\
\hline \multicolumn{7}{|c|}{ In percent of GDP } \\
\hline \multicolumn{7}{|l|}{ Savings-investment balance } \\
\hline Gross domestic investment & 19.2 & 19.8 & 19.6 & 18.0 & 17.1 & 17.9 \\
\hline Private sector & 14.5 & 14.8 & 14.7 & 13.4 & 13.4 & 12.8 \\
\hline Public sector & 4.7 & 5.0 & 4.9 & 4.6 & 3.7 & 5.0 \\
\hline Gross national savings & 21.4 & 20.0 & 20.1 & 18.7 & 16.3 & 15.9 \\
\hline Private sector & 14.9 & 14.2 & 14.4 & 12.6 & 9.9 & 11.0 \\
\hline Public sector & 6.5 & 5.8 & 5.7 & 6.1 & 6.3 & 4.9 \\
\hline \multicolumn{7}{|l|}{ Public sector } \\
\hline Central government primary balance & 2.7 & 1.9 & 1.5 & 1.8 & 3.3 & 0.2 \\
\hline Central government overall balance & 2.0 & 0.6 & 0.1 & 0.9 & 2.6 & -0.7 \\
\hline Consolidated public sector primary balance $2 /$ & 3.2 & 2.8 & 3.7 & 3.4 & 3.9 & 0.3 \\
\hline Consolidated public sector overall balance 2/ & 1.8 & 0.9 & 0.8 & 1.5 & 2.7 & -0.7 \\
\hline Public sector debt (end-of-year) $3 /$ & 45.5 & 38.0 & 27.8 & 21.8 & 20.4 & 20.6 \\
\hline External & 41.3 & 34.6 & 25.4 & 19.9 & 18.6 & 18.9 \\
\hline Domestic & 4.2 & 3.4 & 2.4 & 1.9 & 1.8 & 1.7 \\
\hline Consolidated public sector debt 4 / & 49.2 & 43.0 & 34.2 & 28.2 & 24.9 & 22.8 \\
\hline \multicolumn{7}{|c|}{ Annual percent change } \\
\hline \multicolumn{7}{|l|}{ Money and credit } \\
\hline Monetary base & 17.6 & 4.3 & 13.0 & 35.3 & 18.1 & 25.4 \\
\hline M2 & 24.6 & 16.1 & 15.3 & 38.6 & 21.3 & 8.9 \\
\hline M5 5/ & 12.6 & 8.4 & 16.6 & 8.6 & 15.3 & 7.0 \\
\hline Credit to the private sector $5 /$ & 15.0 & 15.1 & 17.6 & 46.2 & 36.5 & 9.7 \\
\hline Velocity of M2 & 7.7 & 7.2 & 7.0 & 6.4 & 5.7 & 5.3 \\
\hline \multicolumn{7}{|l|}{ Memorandum items: } \\
\hline International reserves (in millions of U.S. dollars) & 1,168 & 1,297 & 1,703 & 2,462 & 2,864 & 2,864 \\
\hline (In months of imports) & 3.4 & 2.8 & 3.2 & 3.2 & 4.3 & 4.0 \\
\hline GDP (in billions of guaranies) & 41,522 & 46,169 & 52,270 & 61,512 & 69,708 & 74,842 \\
\hline Population (millions) & 5.7 & 5.8 & 5.9 & 6.0 & 6.2 & 6.3 \\
\hline
\end{tabular}

Sources: Paraguayan authorities; and Fund staff estimates.

$1 /$ INS calculations of real effective exchange rates.

2/ Consolidated public sector, including the quasi-fiscal operations of the BCP.

3/ Nonfinancial Public Sector. Based on end-of-period exchange rate conversion of U.S. dollar-denominated debt.

4/ Includes Central Bank Bills (LRMs).

5 / Foreign currency items are valued at a constant exchange rate. 
Table 2. Paraguay: Central Government Operations

\begin{tabular}{|c|c|c|c|c|c|c|c|c|c|c|}
\hline & \multirow[t]{2}{*}{2006} & \multirow[t]{2}{*}{2007} & \multicolumn{4}{|c|}{$\frac{2008}{\text { Actual }}$} & \multicolumn{4}{|c|}{$\frac{2009}{\text { Projections }}$} \\
\hline & & & Jan-Mar & Jan-Jun & Jan-Sep & Jan-Dec & Jan-Mar & Jan-Jun & Jan-Sep & Jan-Dec \\
\hline \multicolumn{11}{|c|}{ In billion of guaranies } \\
\hline Total revenues & 9,588 & 10,837 & 3,030 & 6,238 & 9,370 & 12,748 & 2,956 & 6,393 & 9,802 & 13,445 \\
\hline Tax revenues & 6,295 & 7,019 & 1,871 & 4,230 & 6,559 & 8,656 & 1,797 & 4,161 & 6,495 & 8,822 \\
\hline Corporate taxes & 1,009 & 1,229 & 166 & 808 & 1,270 & 1,381 & 160 & 711 & 1,162 & 1,479 \\
\hline Excises & 1,049 & 1,310 & 410 & 830 & 1,209 & 1,555 & 378 & 753 & 1,127 & 1,595 \\
\hline Value added tax & 2,786 & 3,318 & 1,024 & 2,093 & 3,239 & 4,313 & 1,016 & 2,230 & 3,365 & 4,411 \\
\hline Import Duties & 938 & 853 & 243 & 467 & 756 & 1,055 & 229 & 442 & 666 & 1,013 \\
\hline Other & 513 & 309 & 29 & 32 & 86 & 351 & 13 & 26 & 175 & 323 \\
\hline Nontax revenues $1 /$ & 3,262 & 3,794 & 1,156 & 2,006 & 2,809 & 4,064 & 1,155 & 2,224 & 3,294 & 4,606 \\
\hline$o / w$ : Public pension contributions & 560 & 752 & 214 & 420 & 630 & 907 & 269 & 501 & 750 & 949 \\
\hline Itaipu-Yacyreta & 1,883 & 2,042 & 455 & 875 & 1,203 & 1,872 & 640 & 1,178 & 1,640 & 2,303 \\
\hline Capital revenues & 31 & 25 & 2 & 3 & 3 & 28 & 4 & 7 & 12 & 17 \\
\hline Current expenditures: & 7,138 & 7,964 & 1,990 & 4,075 & 6,196 & 8,963 & 2,217 & 4,693 & 7,260 & 10,880 \\
\hline Wages and salaries & 3,857 & 4,360 & 1,167 & 2,364 & 3,574 & 5,216 & 1,309 & 2,628 & 3,977 & 5,919 \\
\hline Goods and services & 674 & 704 & 105 & 274 & 428 & 713 & 116 & 322 & 554 & 1,030 \\
\hline Interest payments & 519 & 515 & 149 & 249 & 356 & 449 & 136 & 259 & 473 & 589 \\
\hline Transfers & 2,067 & 2,366 & 566 & 1,181 & 1,818 & 2,557 & 647 & 1,469 & 2,232 & 3,309 \\
\hline Of which: pensions and benefits & 1,207 & 1,264 & 314 & 637 & 962 & 1,370 & 363 & 774 & 1,177 & 1,745 \\
\hline Other & 22 & 19 & 3 & 7 & 20 & 28 & 9 & 16 & 23 & 33 \\
\hline Capital expenditures and net lending & 2,185 & 2,280 & 255 & 692 & 1,147 & 1,954 & 239 & 723 & 1,534 & 3,000 \\
\hline o/w: Capital expenditure & 1,571 & 1,514 & 103 & 407 & 711 & 1,237 & 100 & 456 & 1,069 & 2,232 \\
\hline $\begin{array}{l}\text { Of which: } \\
\text { Net lending }\end{array}$ & 99 & 132 & -11 & -8 & -13 & -14 & -5 & -11 & -14 & \\
\hline Capital transfers and other & 515 & 634 & 162 & 292 & 448 & 732 & 144 & 278 & 480 & 785 \\
\hline Statistical discrepancy $2 /$ & -216 & 0 & 17 & 25 & 165 & -1 & -111 & -111 & -111 & -111 \\
\hline Overall balance & 48 & 547 & 802 & 1,497 & 2,193 & 1,830 & 389 & 866 & 897 & -545 \\
\hline Financing & -48 & -547 & -803 & $-1,497$ & $-2,193$ & $-1,830$ & -389 & -866 & -897 & 545 \\
\hline External debt (increase +) & -123 & -207 & -175 & -223 & -313 & -334 & -181 & -265 & 160 & 844 \\
\hline Disbursements & 832 & 724 & 95 & 198 & 318 & 495 & 86 & 193 & 905 & 1,791 \\
\hline Amortizations & 955 & 932 & 270 & 421 & 632 & 829 & 268 & 458 & 745 & 946 \\
\hline Domestic bonds (increase + ) & 147 & 186 & 6 & 23 & 23 & 23 & 0 & 100 & 100 & 100 \\
\hline New TB issues & 318 & 382 & 119 & 167 & 167 & 167 & 0 & 217 & 237 & 461 \\
\hline Amortizations & 171 & 196 & 114 & 144 & 144 & 144 & 0 & 117 & 137 & 361 \\
\hline Net credit from the banking system $3 /$ & -375 & -832 & -73 & -687 & $-1,345$ & $-1,478$ & -17 & -510 & -966 & -208 \\
\hline Net credit from Central Bank & -468 & -837 & -29 & -644 & $-1,272$ & $-1,421$ & 70 & -423 & -879 & -121 \\
\hline Net credit from commercial banks & 93 & 4 & -44 & -43 & -73 & -57 & -87 & -87 & -87 & -87 \\
\hline Other & 303 & 307 & -560 & -610 & -610 & -93 & -191 & -191 & -191 & -191 \\
\hline \multicolumn{11}{|c|}{ In percent of GDP } \\
\hline Total revenues & 18.3 & 17.6 & 4.3 & 8.9 & 13.4 & 18.3 & 3.9 & 8.5 & 13.1 & 18.0 \\
\hline Tax revenues: & 12.0 & 11.4 & 2.7 & 6.1 & 9.4 & 12.4 & 2.4 & 5.6 & 8.7 & 11.8 \\
\hline Corporate taxes & 1.9 & 2.0 & 0.2 & 1.2 & 1.8 & 2.0 & 0.2 & 0.9 & 1.6 & 2.0 \\
\hline Excises & 2.0 & 2.1 & 0.6 & 1.2 & 1.7 & 2.2 & 0.5 & 1.0 & 1.5 & 2.1 \\
\hline Value added tax & 5.3 & 5.4 & 1.5 & 3.0 & 4.6 & 6.2 & 1.4 & 3.0 & 4.5 & 5.9 \\
\hline Import duties & 1.8 & 1.4 & 0.3 & 0.7 & 1.1 & 1.5 & 0.3 & 0.6 & 0.9 & 1.4 \\
\hline Other & 1.0 & 0.5 & 0.0 & 0.0 & 0.1 & 0.5 & 0.0 & 0.0 & 0.2 & 0.4 \\
\hline Nontax revenues $1 /$ & 6.2 & 6.2 & 1.7 & 2.9 & 4.0 & 5.8 & 1.5 & 3.0 & 4.4 & 6.2 \\
\hline $\mathrm{O} / \mathrm{W}$ : public pension contributions & 1.1 & 1.2 & 0.3 & 0.6 & 0.9 & 1.3 & 0.4 & 0.7 & 1.0 & 1.3 \\
\hline Itaipu-Yacyreta & 3.6 & 3.3 & 0.7 & 1.3 & 1.7 & 2.7 & 0.9 & 1.6 & 2.2 & 3.1 \\
\hline Capital revenues & 0.1 & 0.0 & 0.0 & 0.0 & 0.0 & 0.0 & 0.0 & 0.0 & 0.0 & 0.0 \\
\hline Current expenditures & 13.7 & 12.9 & 2.9 & 5.8 & 8.9 & 12.9 & 3.0 & 6.3 & 9.7 & 14.5 \\
\hline Wages and salaries & 7.4 & 7.1 & 1.7 & 3.4 & 5.1 & 7.5 & 1.7 & 3.5 & 5.3 & 7.9 \\
\hline Goods and services & 1.3 & 1.1 & 0.2 & 0.4 & 0.6 & 1.0 & 0.2 & 0.4 & 0.7 & 1.4 \\
\hline Interest payments & 1.0 & 0.8 & 0.2 & 0.4 & 0.5 & 0.6 & 0.2 & 0.3 & 0.6 & 0.8 \\
\hline Transfers & 4.0 & 3.8 & 0.8 & 1.7 & 2.6 & 3.7 & 0.9 & 2.0 & 3.0 & 4.4 \\
\hline Capital expenditures and net lending & 4.2 & 3.7 & 0.4 & 1.0 & 1.6 & 2.8 & 0.3 & 1.0 & 2.1 & 4.0 \\
\hline Statistical discrepancy 2/ & -0.4 & -0.1 & 0.0 & 0.0 & 0.2 & 0.0 & 0.0 & 0.0 & 0.0 & 0.0 \\
\hline Overall balance & 0.1 & 0.9 & 1.2 & 2.1 & 3.1 & 2.6 & 0.5 & 1.2 & 1.2 & -0.7 \\
\hline Financing & -0.1 & -0.9 & -1.2 & -2.1 & -3.1 & -2.6 & -0.5 & -1.2 & -1.2 & 0.7 \\
\hline External debt (increase +) & -0.2 & -0.3 & -0.3 & -0.3 & -0.4 & -0.5 & -0.2 & -0.4 & 0.2 & 1.1 \\
\hline Disbursements & 1.6 & 1.2 & 0.1 & 0.3 & 0.5 & 0.7 & 0.1 & 0.3 & 1.2 & 2.4 \\
\hline Amortizations & 1.8 & 1.5 & 0.4 & 0.6 & 0.9 & 1.2 & 0.4 & 0.6 & 1.0 & 1.3 \\
\hline Domestic bonds (increase +) & 0.3 & 0.3 & 0.0 & 0.0 & 0.0 & 0.0 & 0.0 & 0.1 & 0.1 & 0.1 \\
\hline Net credit from the banking system $3 /$ & -0.7 & -1.4 & -0.1 & -1.0 & -1.9 & -2.0 & 0.0 & -0.7 & -1.3 & -0.3 \\
\hline Other & 0.6 & 0.5 & -0.8 & -0.9 & -0.9 & -0.1 & -0.3 & -0.3 & -0.3 & -0.3 \\
\hline \multicolumn{11}{|l|}{ Memorandum Item: } \\
\hline Primary balance & 1.5 & 1.8 & 1.3 & 2.5 & 3.4 & 3.3 & 0.8 & 1.7 & 2.0 & 0.2 \\
\hline Balance of the Caja Fiscal 4/ & -1.2 & -0.8 & -0.1 & -0.3 & -0.5 & -0.7 & 0.0 & 0.0 & 0.0 & 0.0 \\
\hline
\end{tabular}

1/ Includes receipts from the binational hydroelectric plants Itaipu and Yacyreta, and grants.

2/ Measurement error to reconcile above-the-line estimate with measure of the fiscal balance from the financing side.

3/ Excludes banks' holdings of government bonds.

4/ Includes pension payments to central government employees and Chaco War veterans. 
Table 3. Paraguay: Consolidated Public Sector Operations 1/

\begin{tabular}{|c|c|c|c|c|c|c|c|}
\hline & \multirow[t]{2}{*}{2006} & \multirow[t]{2}{*}{2007} & \multicolumn{4}{|c|}{$\begin{array}{c}2008 \\
\text { Actual }\end{array}$} & \multirow{2}{*}{$\begin{array}{c}2009 \\
\text { Proj. } \\
\text { Jan-Dec }\end{array}$} \\
\hline & & & Jan-Mar & Jan-Jun & Jan-Sep & Jan-Dec & \\
\hline \multicolumn{8}{|c|}{ In billion of guaraníes } \\
\hline Revenue & 11,821 & 13,508 & 3,740 & 7,709 & 11,660 & 15,576 & 16,275 \\
\hline Tax revenue & 6,320 & 7,044 & 1,879 & 4,249 & 6,589 & 8,684 & 8,852 \\
\hline Nontax revenue and grants & 5,469 & 6,432 & 1,847 & 3,442 & 5,047 & 6,859 & 7,400 \\
\hline Capital revenue & 32 & 32 & 14 & 18 & 24 & 34 & 23 \\
\hline Current expenditure & 9,177 & 10,191 & 2,522 & 5,215 & 7,953 & 11,506 & 13,379 \\
\hline Wages and salaries & 4,711 & 5,357 & 1,455 & 2,939 & 4,429 & 6,400 & 7,218 \\
\hline Goods and services & 1,200 & 1,194 & 179 & 506 & 799 & 1,308 & 1,617 \\
\hline Interest payments & 858 & 910 & 240 & 449 & 664 & 829 & 743 \\
\hline Transfers & 2,373 & 2,692 & 632 & 1,289 & 2,001 & 2,893 & 3,747 \\
\hline Other & 35 & 38 & 16 & 32 & 59 & 75 & 54 \\
\hline Capital expenditure and net lending & 2,580 & 2,832 & 274 & 884 & 1,501 & 2,582 & 3,664 \\
\hline Of which: capital expenditure & 2,844 & 3,085 & 356 & 1,035 & 1,704 & 2,868 & 3,964 \\
\hline Primary balance & 1,960 & 2,109 & 1,635 & 2,706 & 3,573 & 2,711 & 216 \\
\hline Public enterprises' operating surplus & 1,039 & 715 & 451 & 648 & 703 & 689 & 241 \\
\hline Statistical discrepancy 2/ & -689 & -268 & 0 & -30 & -30 & 0 & 0 \\
\hline Overall balance & 413 & 931 & 1,395 & 2,228 & 2,879 & 2,434 & -527 \\
\hline Financing & -413 & -931 & $-1,395$ & $-2,257$ & $-2,909$ & $-2,464$ & 527 \\
\hline External financing net & -258 & -384 & -198 & -283 & -419 & -346 & 574 \\
\hline Disbursements & 939 & 724 & 95 & 198 & 330 & 593 & 574 \\
\hline Amortizations & 1,197 & 1,109 & 293 & 480 & 750 & 939 & 1,161 \\
\hline Domestic financing net & -476 & -547 & -638 & $-1,364$ & $-1,879$ & $-2,025$ & 144 \\
\hline Bond financing & 147 & 186 & 6 & 23 & 23 & 23 & 100 \\
\hline Net credit from the banking system & -728 & -777 & -660 & $-1,464$ & $-2,052$ & $-2,264$ & -186 \\
\hline Quasifiscal deficit financing & 105 & 44 & 17 & 76 & 150 & 216 & 230 \\
\hline Other & 320 & 0 & -560 & -610 & -610 & -93 & -191 \\
\hline \multicolumn{8}{|c|}{ In percent of GDP } \\
\hline Revenue & 22.6 & 22.0 & 5.4 & 11.1 & 16.7 & 22.3 & 21.7 \\
\hline Tax revenue & 12.1 & 11.5 & 2.7 & 6.1 & 9.5 & 12.5 & 11.8 \\
\hline Nontax revenue and grants & 10.5 & 10.5 & 2.6 & 4.9 & 7.2 & 9.8 & 9.9 \\
\hline Capital revenue & 0.1 & 0.1 & 0.0 & 0.0 & 0.0 & 0.0 & 0.0 \\
\hline Current expenditure & 17.6 & 16.6 & 3.6 & 7.5 & 11.4 & 16.5 & 17.9 \\
\hline Wages and salaries & 9.0 & 8.7 & 2.1 & 4.2 & 6.4 & 9.1 & 9.6 \\
\hline Goods and services & 2.3 & 1.9 & 0.3 & 0.7 & 1.1 & 1.8 & 2.2 \\
\hline Interest payments & 1.6 & 1.5 & 0.3 & 0.6 & 1.0 & 1.2 & 1.0 \\
\hline Transfers & 4.5 & 4.4 & 0.9 & 1.8 & 2.9 & 4.2 & 5.0 \\
\hline Other & 0.1 & 0.1 & 0.0 & 0.0 & 0.1 & 0.1 & 0.1 \\
\hline Capital expenditure and net lending & 4.9 & 4.6 & 0.4 & 1.3 & 2.2 & 3.7 & 4.9 \\
\hline Of which: capital expenditure & 4.9 & 4.6 & 0.4 & 1.3 & 2.2 & 3.7 & 4.9 \\
\hline Public enterprises' operating surplus & 2.0 & 1.2 & 0.6 & 0.9 & 1.0 & 0.5 & 0.3 \\
\hline Statistical discrepancy 2/ & -1.3 & 0.0 & 0.0 & 0.0 & 0.0 & 0.0 & 0.0 \\
\hline Overall balance & 0.8 & 1.5 & 2.0 & 3.2 & 4.1 & 2.7 & -0.7 \\
\hline Financing & -0.8 & -1.5 & -2.0 & -3.2 & -4.2 & -2.7 & 0.7 \\
\hline External financing net & -0.5 & -0.6 & -0.3 & -0.4 & -0.6 & -0.6 & 0.8 \\
\hline Disbursements & 1.8 & 1.2 & 0.1 & 0.3 & 0.5 & 0.8 & 2.3 \\
\hline Amortizations & 2.3 & 1.8 & 0.0 & 0.0 & 0.0 & 1.4 & 0.0 \\
\hline Domestic financing net & -0.9 & -0.9 & -0.9 & -2.0 & -2.7 & -2.1 & 0.2 \\
\hline Of which: quasifiscal deficit financing & 0.2 & 0.1 & 0.0 & 0.1 & 0.2 & 0.3 & 0.3 \\
\hline Other & 0.6 & 0.0 & -0.8 & -0.9 & -0.9 & -0.1 & -0.3 \\
\hline \multicolumn{8}{|l|}{ Memorandum item: } \\
\hline Primary balance & 3.7 & 3.4 & 2.3 & 3.9 & 5.1 & 3.9 & 0.3 \\
\hline
\end{tabular}

Sources: Ministry of Finance and Fund staff estimates.

1/ Public sector comprises only the nonfinancial public sector and the Central Bank.

2/ Measurement error to reconcile above the line estimate with estimates of the fiscal balance from the financing side. 


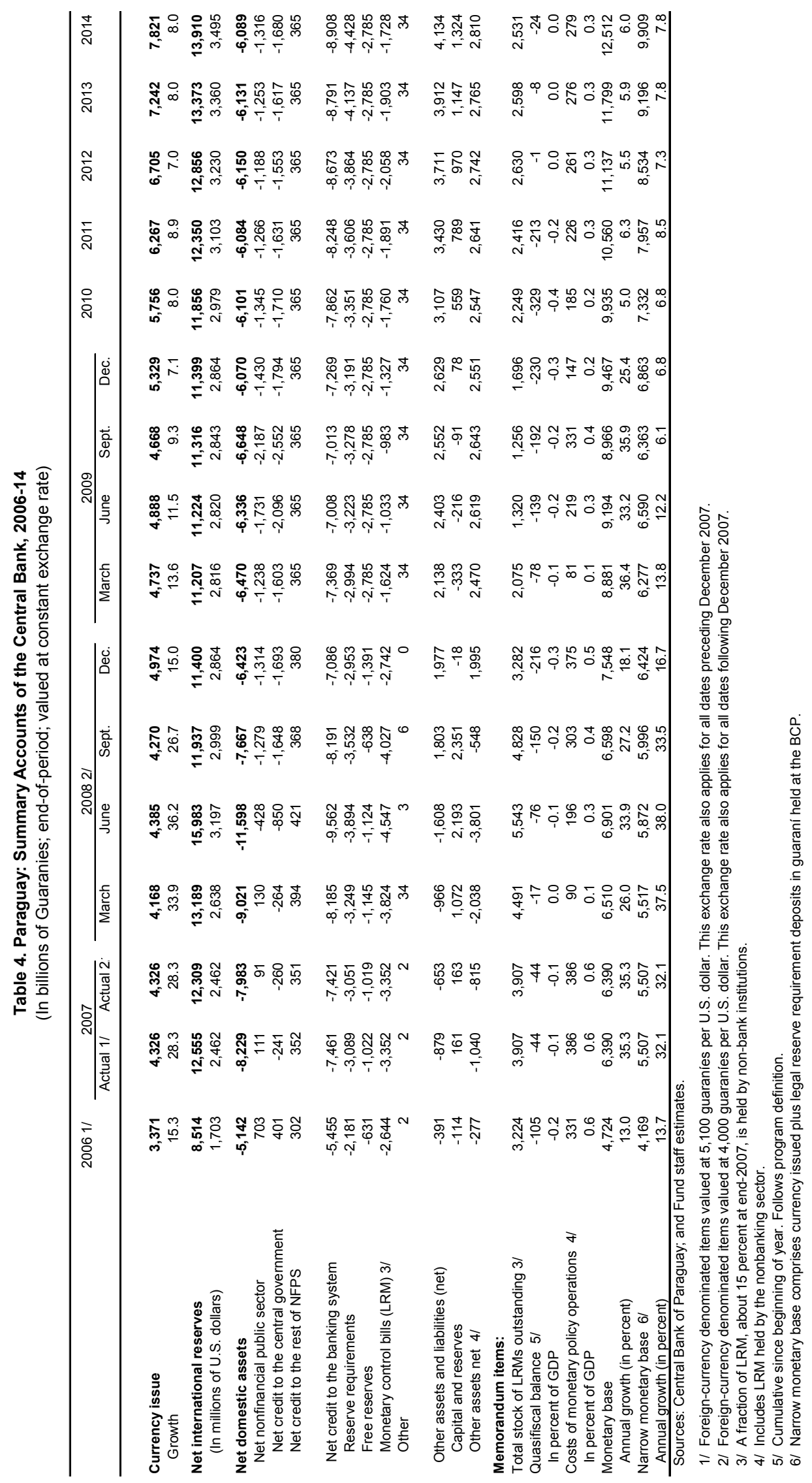




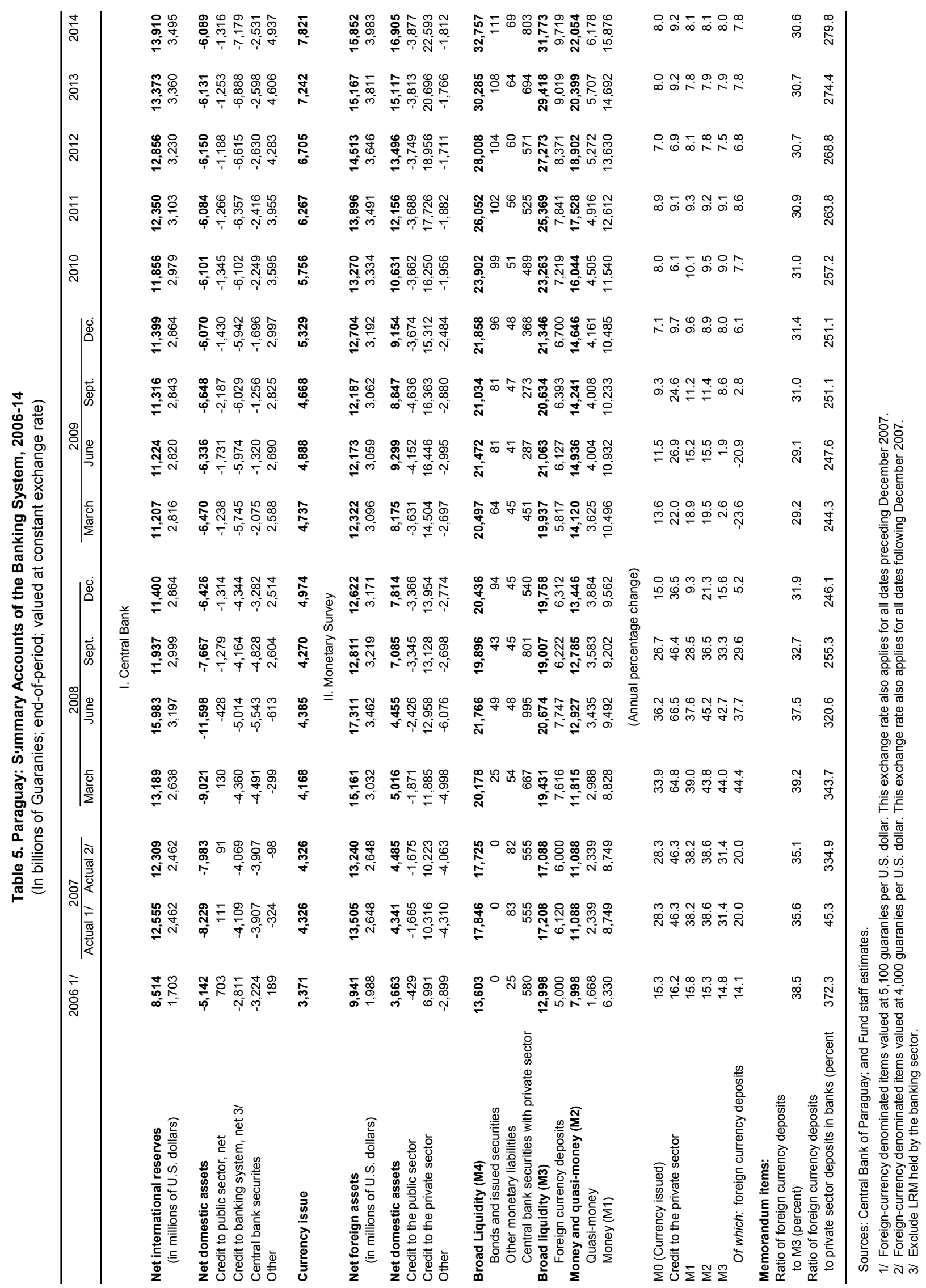


Table 6. Paraguay: Banking System Indicators

\begin{tabular}{|c|c|c|c|c|c|}
\hline & 2003 & 2004 & 2005 & 2006 & 2007 \\
\hline \multicolumn{6}{|c|}{ I. Total banking system $(|\mathrm{II}+| \mathrm{II+IV+V})$} \\
\hline Share in assets & 100.0 & 100.0 & 100.0 & 100.0 & 100.0 \\
\hline Capital adequacy ratio (percent) $1 /$ & 20.9 & 20.5 & 20.4 & 20.1 & 16.8 \\
\hline NPLs/total loans & 20.6 & 10.8 & 6.6 & 3.3 & 1.3 \\
\hline Provisions/NPLs & 54.8 & 54.6 & 57.7 & 59.1 & 78.2 \\
\hline Rate of return on assets (ROA) & 0.4 & 1.7 & 2.1 & 3.0 & 2.8 \\
\hline Rate of return on equity (ROE) & 4.5 & 18.3 & 22.6 & 31.7 & 34.7 \\
\hline Liquid assets/total assets $2 /$ & 32.6 & 30.8 & 26.6 & 23.3 & 24.3 \\
\hline Foreign exchange deposits/total deposits & 61.7 & 55.0 & 52.7 & 49.1 & 44.3 \\
\hline \multicolumn{6}{|c|}{ II. Total foreign-owned banks } \\
\hline Share in assets & 47.4 & 35.8 & 31.3 & 29.1 & 28.4 \\
\hline Capital adequacy ratio (percent) $1 /$ & 20.4 & 26.0 & 27.2 & 25.5 & 20.6 \\
\hline NPLs/total loans & 20.8 & 11.0 & 6.4 & 3.6 & 1.5 \\
\hline Provisions/NPLs & 64.2 & 71.2 & 63.4 & 68.6 & 53.6 \\
\hline Rate of return on assets (ROA) & 0.1 & 1.4 & 1.4 & 2.2 & 1.2 \\
\hline Rate of return on equity (ROE) & 1.2 & 12.0 & 11.3 & 18.6 & 13.1 \\
\hline Liquid assets/total assets $2 /$ & 29.8 & 25.4 & 29.0 & 24.5 & 25.5 \\
\hline Foreign exchange deposits/total deposits & 65.6 & 65.2 & 65.1 & 61.2 & 55.4 \\
\hline \multicolumn{6}{|c|}{ III. Total majority-owned foreign banks } \\
\hline Share in assets & 37.2 & 45.2 & 48.0 & 51.4 & 51.7 \\
\hline Capital adequacy ratio (percent) $1 /$ & 21.0 & 17.7 & 17.8 & 17.4 & 15.1 \\
\hline NPLs/total loans & 12.3 & 3.7 & 2.3 & 1.8 & 0.9 \\
\hline Provisions/NPLs & 52.1 & 56.9 & 87.2 & 83.0 & 91.5 \\
\hline Rate of return on assets (ROA) & 1.3 & 2.2 & 3.0 & 3.9 & 4.1 \\
\hline Rate of return on equity (ROE) & 15.5 & 25.8 & 35.3 & 45.8 & 53.5 \\
\hline Liquid assets/total assets $2 /$ & 35.3 & 28.8 & 22.6 & 18.5 & 21.1 \\
\hline Foreign exchange deposits/total deposits & 62.3 & 53.8 & 51.7 & 48.8 & 42.8 \\
\hline \multicolumn{6}{|c|}{ IV. Total domestic-owned private banks } \\
\hline Share in assets & 7.4 & 8.2 & 9.4 & 9.9 & 11.3 \\
\hline Capital adequacy ratio (percent) $1 /$ & 14.1 & 13.3 & 13.4 & 15.6 & 12.2 \\
\hline NPLs/total loans & 2.9 & 2.1 & 0.8 & 1.4 & 0.8 \\
\hline Provisions/NPLs & 46.2 & 70.3 & 77.1 & 78.6 & 95.0 \\
\hline Rate of return on assets (ROA) & 1.6 & 2.0 & 2.2 & 2.9 & 2.7 \\
\hline Rate of return on equity (ROE) & 21.1 & 28.1 & 30.8 & 35.9 & 38.3 \\
\hline Liquid assets/total assets $2 /$ & 38.8 & 38.1 & 34.0 & 34.6 & 28.2 \\
\hline Foreign exchange deposits/total deposits & 60.7 & 57.6 & 54.7 & 51.5 & 51.6 \\
\hline \multicolumn{6}{|c|}{ V. National Development Bank (BNF) } \\
\hline Share in assets & 8.0 & 10.7 & 11.3 & 9.5 & 8.5 \\
\hline Capital adequacy ratio (percent) $1 /$ & 30.0 & 25.0 & 26.5 & 32.2 & 35.5 \\
\hline NPLs/total loans & 56.2 & 48.9 & 40.3 & 19.4 & 7.8 \\
\hline Provisions/NPLs & 47.6 & 43.1 & 45.1 & 31.6 & 76.9 \\
\hline Rate of return on assets (ROA) & -2.8 & 0.5 & 0.4 & 0.5 & 0.4 \\
\hline Rate of return on equity (ROE) & -18.7 & 6.8 & 5.3 & 5.7 & 5.3 \\
\hline Liquid assets/total assets $2 /$ & 30.7 & 52.0 & 31.2 & 33.8 & 34.5 \\
\hline Foreign exchange deposits/total deposits & 32.7 & 23.6 & 20.6 & 13.1 & 8.8 \\
\hline
\end{tabular}

Source: Superintendency of Banks.

1/ Definition of CAR does not fully comply with international standards.

2/ Liquid assets are calculated as the sum of cash, reserves, accounts in banks and lending in interbank market. 


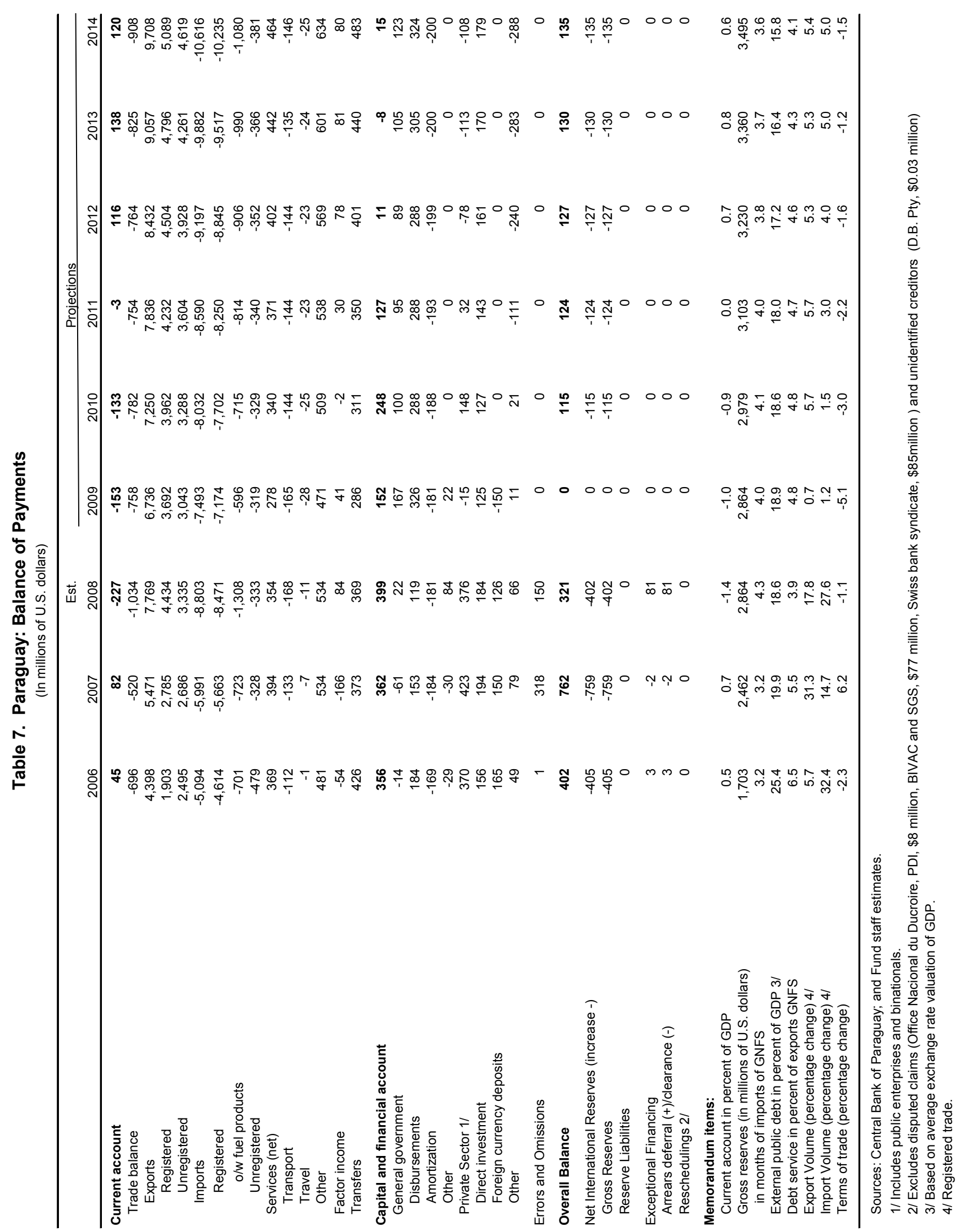


Table 8. Paraguay: Indicators of External Vulnerability

\begin{tabular}{|c|c|c|c|c|c|c|}
\hline & 2003 & 2004 & 2005 & 2006 & 2007 & 2008 \\
\hline \multicolumn{7}{|l|}{ Monetary and financial indicators } \\
\hline Broad money (M3), percentage change $1 /$ & 18.3 & 13.5 & 10.0 & 14.8 & 31.5 & 15.6 \\
\hline Credit to the private sector, real (percentage change) $1 /$ & -25.7 & 12.0 & 4.9 & 3.5 & 38.2 & 27.0 \\
\hline Share of nonperforming loans in total loans (percent) 2/ & 20.6 & 10.8 & 6.6 & 3.3 & 1.3 & 1.2 \\
\hline Average domestic lending rate, real & 19.3 & 17.4 & 18.5 & 15.4 & 19.2 & 20.7 \\
\hline Central Bank bill yield, real & -1.2 & 1.0 & -0.1 & 0.8 & 1.3 & 1.6 \\
\hline International reserves (millions of US\$) & 983 & 1,168 & 1,297 & 1,703 & 2,462 & 2,864 \\
\hline Central bank foreign short-term liabilities (millions of US\$) & 0.5 & 0.3 & 0.7 & 0.0 & 0.3 & 0.0 \\
\hline \multicolumn{7}{|l|}{ External indicators } \\
\hline Merchandise exports (percentage change) & 16.8 & 32.0 & 17.4 & 31.2 & 24.4 & 42.0 \\
\hline Merchandise imports (percentage change) & 14.4 & 27.0 & 22.9 & 33.7 & 17.6 & 46.9 \\
\hline Merchandise terms of trade (percentage change) & 0.1 & -1.4 & -9.9 & -2.3 & 6.2 & -1.1 \\
\hline Real effective exchange rate (percentage change) & -6.6 & 3.7 & -6.5 & 13.0 & 10.8 & 16.4 \\
\hline Current account balance (percent of GDP) & 2.3 & 2.1 & 0.3 & 0.5 & 0.7 & -1.4 \\
\hline Capital and financial account (percent of GDP) & 3.2 & 0.6 & 5.3 & 3.8 & 3.0 & 2.5 \\
\hline Net foreign direct investment (percent of GDP) & 0.4 & 0.5 & 0.6 & 1.7 & 1.6 & 1.1 \\
\hline Inward portfolio investment (percent of GDP) & 0.0 & 0.0 & 0.0 & 0.0 & 0.0 & 0.0 \\
\hline Other net investment (percent of GDP) & 2.6 & -0.1 & 4.4 & 1.8 & 1.1 & 1.1 \\
\hline External public debt (percent of GDP) 2/ & 48.1 & 41.3 & 34.6 & 25.4 & 19.9 & 18.6 \\
\hline Debt service (in percent of exports GNFS) & 11.5 & 7.3 & 8.7 & 6.5 & 5.5 & 3.9 \\
\hline Gross reserves (in US\$ million) & 984 & 1,168 & 1,298 & 1,703 & 2,462 & 2,864 \\
\hline In months of imports of GNFS & 3.5 & 3.4 & 2.8 & 3.2 & 3.2 & 4.3 \\
\hline Over short-term external debt $3 /$ & 1.7 & 1.7 & 1.9 & 2.6 & 3.9 & 4.3 \\
\hline Over foreign currency deposits in domestic banks & 1.0 & 1.2 & 1.3 & 1.5 & 1.9 & 1.6 \\
\hline
\end{tabular}

Sources: Central Bank of Paraguay; and Fund staff estimates.

1/ Foreign currency components are valued at the accounting exchange rate.

2/ Based on end-of-period exchange rate conversion of U.S. dollar-denominated debt.

3/ Private and public external debt with a residual maturity of one year or less. Excludes foreign currency deposits in banking system. 
Table 9. Paraguay: Medium-Term Scenario

\begin{tabular}{|c|c|c|c|c|c|c|c|c|c|c|c|}
\hline & \multirow[b]{2}{*}{2004} & \multirow[b]{2}{*}{2005} & \multirow[b]{2}{*}{2006} & \multirow[b]{2}{*}{2007} & \multicolumn{7}{|c|}{ Projections } \\
\hline & & & & & 2008 & 2009 & 2010 & 2011 & 2012 & 2013 & 2014 \\
\hline \multicolumn{12}{|l|}{ Real sector } \\
\hline Real GDP growth (annual percentage change) & 4.1 & 2.9 & 4.3 & 6.8 & 5.8 & 0.5 & 1.5 & 3.0 & 4.0 & 5.0 & 5.0 \\
\hline Consumer prices (annual percentage change) & 2.8 & 9.8 & 12.5 & 5.9 & 7.5 & 5.5 & 5.0 & 4.0 & 3.0 & 3.0 & 3.0 \\
\hline GDP per capita (US dollars) & 1,216 & 1,292 & 1,568 & 2,026 & 2,601 & 2,356 & 2,366 & 2,426 & 2,517 & 2,637 & 2,761 \\
\hline \multicolumn{12}{|c|}{ (In percent of GDP) } \\
\hline Gross domestic investment & 19.2 & 19.8 & 19.6 & 18.0 & 17.1 & 17.9 & 19.4 & 19.9 & 20.4 & 20.2 & 20.1 \\
\hline Private sector & 14.5 & 14.8 & 14.7 & 13.4 & 13.4 & 12.8 & 13.5 & 13.9 & 14.2 & 14.4 & 14.6 \\
\hline Public sector & 4.7 & 5.0 & 4.9 & 4.6 & 3.7 & 5.0 & 6.0 & 6.0 & 6.2 & 5.8 & 5.6 \\
\hline Gross national savings & 21.4 & 20.0 & 20.1 & 18.7 & 16.3 & 15.9 & 16.9 & 17.9 & 18.8 & 19.6 & 20.5 \\
\hline Private sector & 14.9 & 14.2 & 14.4 & 12.6 & 9.9 & 11.0 & 10.4 & 11.0 & 11.5 & 12.2 & 12.7 \\
\hline Public sector & 6.5 & 5.8 & 5.7 & 6.1 & 6.3 & 4.9 & 6.4 & 6.9 & 7.3 & 7.4 & 7.7 \\
\hline \multicolumn{12}{|l|}{ Public finances $1 /$} \\
\hline Revenues & 21.6 & 21.9 & 22.6 & 22.0 & 22.3 & 21.8 & 21.9 & 22.2 & 22.6 & 22.4 & 22.4 \\
\hline Current primary expenditures & 15.1 & 15.5 & 15.9 & 15.1 & 15.3 & 16.9 & 17.1 & 17.0 & 16.9 & 16.7 & 16.5 \\
\hline Interest payments & 1.6 & 1.6 & 1.6 & 1.5 & 1.2 & 1.0 & 1.0 & 1.0 & 1.1 & 1.1 & 1.2 \\
\hline Capital expenditures & 4.7 & 5.0 & 4.9 & 4.6 & 3.7 & 4.9 & 5.2 & 5.3 & 5.3 & 5.1 & 5.2 \\
\hline Public enterprise operating surplus & 1.4 & 1.4 & 2.0 & 1.2 & 0.5 & 0.3 & 0.5 & 0.5 & 0.5 & 0.4 & 0.2 \\
\hline Primary balance & 3.2 & 2.8 & 3.7 & 3.4 & 3.9 & 0.3 & 0.2 & 0.5 & 0.9 & 0.9 & 1.0 \\
\hline Overall balance & 1.8 & 0.9 & 0.8 & 1.5 & 2.7 & -0.7 & -0.8 & -0.6 & -0.2 & -0.2 & -0.1 \\
\hline Public sector debt 2/ 3/ & 45.1 & 37.7 & 27.7 & 21.8 & 19.3 & 19.5 & 19.2 & 18.6 & 17.8 & 17.0 & 16.3 \\
\hline Consolidated public sector debt 3 / & 49.2 & 43.0 & 34.2 & 28.3 & 23.9 & 21.8 & 22.1 & 21.5 & 20.7 & 19.7 & 18.7 \\
\hline \multicolumn{12}{|c|}{ (In millions of U.S. dollars) } \\
\hline Public sector debt $2 /$ & 3,027 & 2,876 & 2,807 & 2,766 & 2,729 & 2,826 & 2,879 & 2,928 & 2,977 & 3,041 & 3,107 \\
\hline \multicolumn{12}{|l|}{ Balance of payments } \\
\hline Exports & 2,854 & 3,352 & 4,398 & 5,471 & 7,769 & 6,736 & 7,250 & 7,836 & 8,432 & 9,057 & 9,708 \\
\hline Imports & 3,102 & 3,811 & 5,094 & 5,991 & 8,803 & 7,493 & 8,032 & 8,590 & 9,197 & 9,882 & 10,616 \\
\hline Current account & 143 & 19 & 45 & 82 & -227 & -153 & -133 & -3 & 116 & 138 & 120 \\
\hline (In percent of GDP) & 2.1 & 0.3 & 0.5 & 0.7 & -1.4 & -1.0 & -0.9 & 0.0 & 0.7 & 0.8 & 0.6 \\
\hline Capital and financial account & 41 & 397 & 356 & 362 & 399 & 152 & 248 & 127 & 11 & -8 & 15 \\
\hline Gross international reserves & 1,168 & 1,298 & 1,703 & 2,462 & 2,864 & 2,864 & 2,979 & 3,103 & 3,230 & 3,360 & 3,495 \\
\hline (In months of imports) & 3.4 & 2.8 & 3.2 & 3.2 & 4.3 & 4.0 & 4.1 & 4.0 & 3.8 & 3.7 & 3.6 \\
\hline
\end{tabular}

Sources: Ministry of Finance; Central Bank of Paraguay; and Fund staff estimates and projections.

$1 /$ Defined as the nonfinancial public sector and the BCP.

2/ Nonfinancial public sector debt; excludes Central Bank bills.

3/ Based on end-of-period exchange rate conversion of U.S. dollar-denominated debt. 


\section{APPEndix 1: DebT SuStainability Analysis}

\section{Paraguay's external and public debt outlook is quite robust to alternative} assumptions for the underlying macroeconomic variables. Indeed, a scenario setting key variables at their historical averages significantly improves the overall debt dynamics beyond the baseline. Additional temporary negative shocks to key variables, such as interest rates, the exchange rate, and GDP growth, would lead to some increase in the level of public and external debt, but the ratios return to a declining path once conditions normalize.

\section{Public debt levels are quite low and are likely to remain so under various scenarios.} Under the baseline scenario, the debt-to-GDP ratio is expected to decline from 19 percent to 15 percent. Under the most adverse scenario, the debt level would rise to about 27 by 2014 . The main risks to debt sustainability that are not explicitly considered in the current DSA framework are a sharper and prolonged decline in GDP growth should the global crisis prove far worse than expected, and approval by Congress of highly expansionary expenditure policies.

\section{Similarly, external debt levels remain low and are projected to remain around} 20 percent of GDP in the medium term. Paraguay has been conservative in contracting external debt. Given strong real GDP growth over the past few years, this contributed to a significant reduction in external debt in 2008 to below 20 percent of GDP from almost 25 percent in 2007. In the coming years, external debt ratio is expected to increase by about 2 percentage points of GDP due to the increase donor financing of public investment and the below-trend GDP growth as a result of the global recession. In the medium term, debt ratios will stabilize as growth returns to its trend level. The shock simulations indicate that the extreme shock would be that of currency deprecation, which would raise the debt to GDP ratio by about 10 percentage points in the medium term. 
Figure Al.1 . Paraguay: Public Debt Sustainability: Bound Tests 1/ (Public debt in percent of GDP)


Primary balance shock (in percent of GDP) an no policy change scenario (constant primary balaı

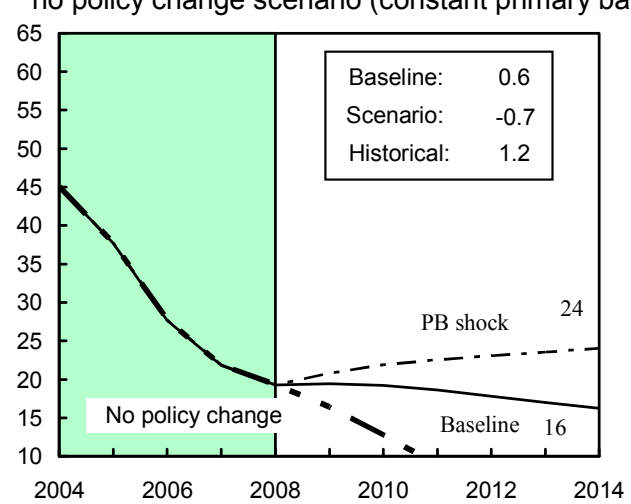

Combined shock 2/

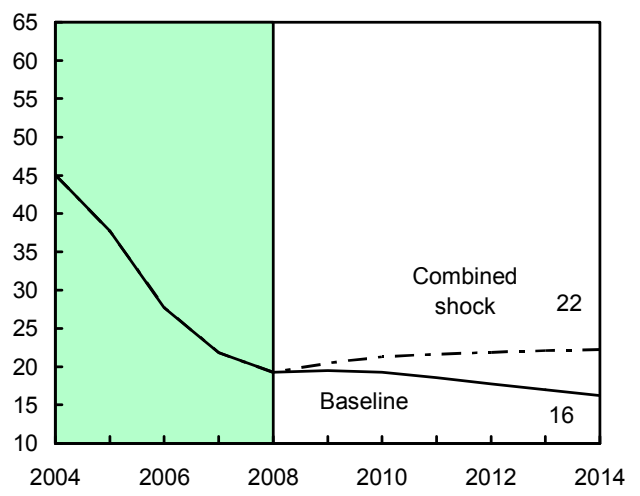

Real depreciation and contingent liabilities shocks?

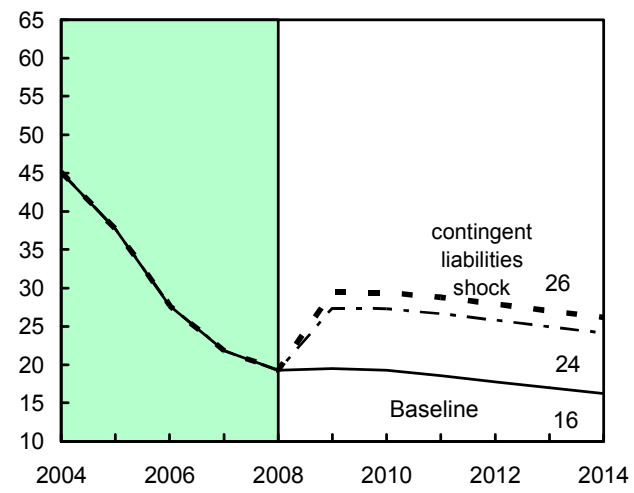

Sources: International Monetary Fund, country desk data, and staff estimates.

$1 /$ Shaded areas represent actual data. Individual shocks are permanent one-half standard deviation shocks. Figures in the boxes represent average projections for the respective variables in the baseline and scenario being presented. Ten-year historical average for the variable is also shown.

2/ Permanent 1/4 standard deviation shocks applied to real interest rate, growth rate, and primary balance.

3 / One-time real depreciation of 30 percent and 10 percent of GDP shock to contingent liabilities occur in 2009, with real depreciation defined as nominal depreciation (measured by percentage fall in dollar value of local currency) minus domestic inflation (based on GDP deflator). 
Figure AI.2. Paraguay: External Debt Sustainability: Bound Tests 1/ (External debt in percent of GDP)
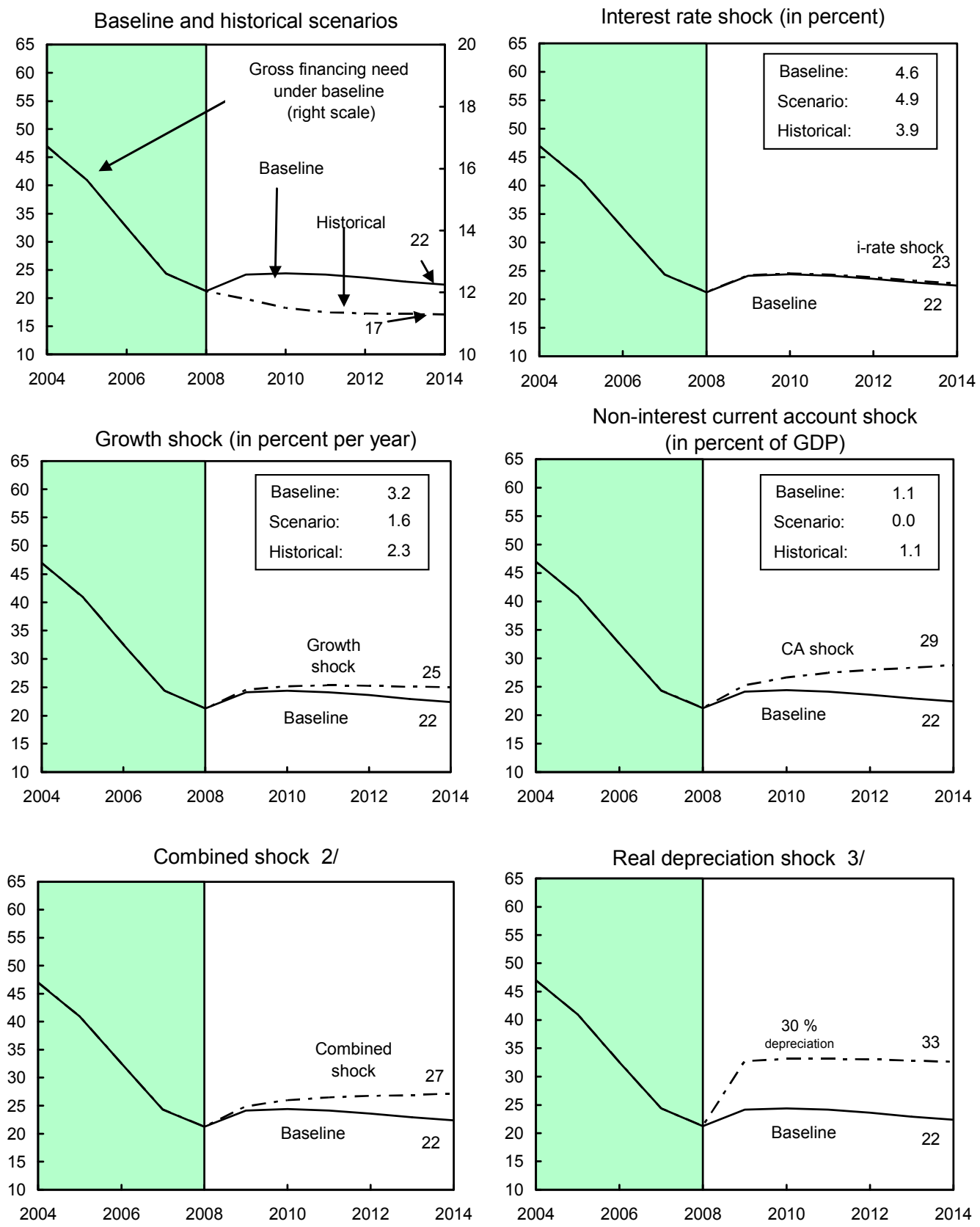

Sources: International Monetary Fund, Country desk data, and staff estimates.

1/ Shaded areas represent actual data. Individual shocks are permanent one-half standard deviation shocks. Figures in the boxes represent average projections for the respective variables in the baseline and scenario being presented. Ten-year historical average for the variable is also shown.

2/ Permanent 1/4 standard deviation shocks applied to real interest rate, growth rate, and current account balance.

3/ One-time real depreciation of 30 percent occurs in 2009. 


\section{APPENDix 2: FinAnCial Sector Reform Agenda}

The financial system in Paraguay continues to recover after several years of financial distress. Even in the midst of the global financial crisis, the banking sector remains liquid, well-capitalized, and profitable, while the growth of deposits and credit to the private sector remains strong. The authorities continue the implementation of their ambitious reform agenda, started in 2004, and significant progress has been achieved in several areas, including strengthening the regulation and supervision of banks and cooperatives, developing the incipient capital markets, and revamping the payment systems.

\section{Strengthening the Financial Position of the BCP}

The authorities intend to implement a new strategy to recapitalize the $\mathrm{BCP}$. The previous strategy to strengthen the financial position of the Central Bank - the capital need is estimated at about 6 percent of GDP - contemplated resolving the flow and stock problems sequentially. ${ }^{1}$ However, given that the former strategy involved resolving old account discrepancies between BCP and the Ministry of Finance, it would have been exceedingly difficult to implement politically.

- $\quad$ The new strategy involves resolving the stock problem of the BCP by transferring in several tranches marketable bonds by the 6 percent of GDP needed, regardless of the pending reconciliation issues, which will continue in parallel. At the end of the process, the Treasury bonds will replace LRMs in the market. The authorities expect to send legislation to Congress to this end by end-2009.

\section{Banking Supervision and Regulation}

In June 2007 the Paraguayan authorities designed a strategy to improve banking regulation and supervision, and increase compliance with the Basel Core Principles for Effective Banking Supervision (BCPs). The strategy included the following steps: ${ }^{2}$

- $\quad$ Approval of amended Resolution 8 on credit requirements, portfolio classification, and provisioning requirements by September 2007. The resolution was approved and entered into effect fully in October 2008 (as Resolution 1). This rule established:

(i) stricter information requirements for the granting of loans; (ii) more stringent

\footnotetext{
${ }^{1}$ The strategy contemplated the following steps: (i) increase BCP's income by a guarantee to cover losses up to 0.3 percent of GDP by transfers from the central government budget; (ii) regularize claims between Central Bank and Ministry of Finance that are uncontroversial and not subject to legal dispute; (iii) obtain the certification of the Attorney General the quantification and resolution of disputed claims between the BCP and the Ministry of Finance; and (iv) once legal clarification has been obtained, write-off nonperforming assets from the Central Bank balance sheet, and recapitalize the Central Bank with bonds.

2 According to the last FSAP assessment conducted in 2005, Paraguay only fully or partially complied with 20 percent of the Principles.
} 
criteria for portfolio classification; and (iii) higher provisioning requirements for the nonperforming loan portfolio.

- Implementation of regulations on the opening of financial institutions and credit risk management practices, and strengthening of the Superintendency of Banks (SBP) financial risk unit by December 2007. For the first time, the SBP prepared a draft rule establishing criteria for the opening of new financial institutions and introducing internal procedures for the analysis of the related applications. The SBP finalized the regulation on credit risk management practices, which entered into effect in January 2009, and introduced a generic provision of up to 1.5 percent of the total portfolio, increasing the provision coverage significantly. The SBP also reinforced its financial risk unit by increasing the number of professional staff and launching an active training program.

- Implementation, by end-2008, of additional regulatory reforms including those related to the strengthening of on-site and off-site supervision, and the improvement of financial and operational risk management practices. The SBP also created a new Financial Stability unit to coordinate the work related to the impact of the financial crisis. In addition, since end-2008, SBP supervisors are protected legally by an insurance policy to cover the legal defense costs that the officials may incur.

- Modification, by end-2010, of the current banking legislation and regulations (including the General Banking Law, GBL; and the Organic Law of the Central Bank, OLCB) with a view to increasing the independence, sanctioning capacity, management capacity, and corporate governance rules of the SBP and strengthening capital requirements. The authorities intend to send to Congress amendments to the laws that address these deficiencies in 2009 . Congress approval is expected by end2010.

\section{Developing Capital Markets}

In February 2008, the authorities adopted a strategy for the development of capital markets. Key elements of the strategy included: (i) improving the general business environment; (ii) enhancing the securities market regulation; (iii) and developing market infrastructure. In order to make the strategy more operational, a number of priority measures need to be implemented, including: (i) the development of mechanisms for cooperation and information sharing among key institutions such as the Comisión Nacional de Valores (CNV), Superintendency of Banks and Superintendency of Insurance; (ii) amend requirements for rating agencies to facilitate their operations; and (iii) approve the laws related to payment systems (central security depository, dematerialization of securities, and clearing and settlement). 
- $\quad$ The law amending the requirements for the operation of rating agencies has already been cleared at the technical level by the BCP, SBP and CNV, and is awaiting approval in the Senate. The new law will allow for the replacement of the publishing of the SBP rating system, CAMEL, for ratings by independent firms. ${ }^{3}$

- $\quad$ A draft of a formal Memorandum of Understanding for information sharing between $\mathrm{CNV}$ and SBP has been prepared, and is expected to enter into effect in the coming months.

- The CNV has received important additional budgetary resources for the 2009 period, which will allow the institution to increase its staff, provide further training, and expand and upgrade its technological requirements.

\section{Upgrading the Payments System}

The authorities are working on legal and infrastructure improvements to the payments system. The current payments system in Paraguay is quite weak. The infrastructure for payments, clearing and settlements of securities remains basic, risky and inefficient; and an adequate legal framework for settlement, dematerialization, custody, netting arrangement, repo operations, and electronic transactions is lacking.

- With IMF and World Bank TA, the government has prepared a draft law to significantly address these weaknesses. The law, which is awaiting the final approval of the Economic Cabinet and is expected to be sent to Congress soon, will cover the legal framework for the Real Time Gross Settlement (RGTS) system, the securities depository, and the Automatic Clearing House. The law will also formally entrust the oversight and regulation of the entire payment system to the BCP.

- $\quad$ At the same time, the World Bank is providing TA and financial assistance to the BCP to set up the infrastructure for an automated RTGS. The pre-qualification process for designating a technology vendor will start soon. The BCP authorities have already provided financial resources for up to US\$4 million to complete the project.

\section{Strengthening the Supervision and Regulation of the Cooperative Sector}

The authorities are also implementing a number of reforms to improve the regulation and supervision of financial cooperatives. Cooperatives are steadily increasing their participation in the financial system accounting for approximately 25 percent of deposits and

\footnotetext{
${ }^{3}$ The legal requirement of publishing the supervisory entity's own rating of financial institutions was considered by the 2005 FSAP a practice not in line with international accepted standards (Basel Core Principles).
} 
28 percent of credits by end-2008. ${ }^{4}$ The "General Regulatory Framework for Cooperatives", which entered into effect in 2007, aimed at establishing capital requirements, classification of loans and provisioning requirements, liquidity requirements, as well as introducing a basic framework for carrying out effective supervision by enhancing information requirements, insitu and extra-situ supervision. However, an effective supervisory framework is still being developed, as norms governing the operations of cooperatives are less stringent than those for banks and finance companies. ${ }^{5}$ Priorities in this area include (i) strengthening supervision and auditing regulations; (ii) strengthening the system of statistics and data analysis; and (iii) enhancing the administrative and operational capacities of the supervisory agency (INCOOP).

- $\quad$ By end-2009, the twenty largest cooperatives will report monetary and financial statistics to the BCP. In the next months, INCOOP and BCP will sign a Memorandum of Understanding to this end.

- The authorities are working on the establishment of a deposit insurance fund, which they expect to be ready by end-2009. The draft law intends to establish a deposit insurance coverage of 55 minimum salaries or US\$14,000 - the coverage for banks and finance companies is of 75 minimum salaries - which will cover approximately 97 percent of the total 620,000 accounts.

- The authorities have launched a pilot project on a credit bureau. This is expected to be fully operational by early 2010 .

INCOOP has received US\$3 million from the IDB for a program of institutional strengthening that will cover training, technological upgrade, and advice for enhancing regulation and supervision.

\footnotetext{
${ }^{4}$ Cooperatives have approximately 820,000 associates, with about US $\$ 1$ billion in credits. The twenty largest cooperatives (Type A cooperatives) account for about 75 percent of deposits of the cooperatives system.

${ }^{5}$ For example, there are no minimum capital requirements for cooperatives, versus a requirement of US\$3 million for banks and US\$1.5 million for finance companies; and risk-weighted capital adequacy requirements are 10 percent for banks and finance companies, whereas cooperatives have a reserve requirement of 8,6 , and 4 percent depending on their size.
} 


\section{INTERNATIONAL MONETARY FUND}

\section{PARAGUAY}

\section{Staff Report for the 2009 Article IV Consultation-Informational Annex}

Prepared by the Staff Representatives for the 2009 Consultation with Paraguay

Approved by José Fajgenbaum and Daneshwar Ghura

April 20, 2009

Contents

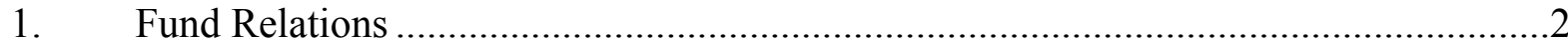

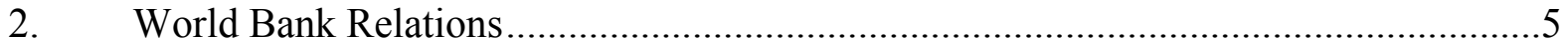

3. Inter-American Development Bank Relations ................................................

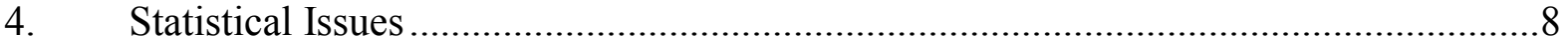


Annex 1. Paraguay-Fund Relations

(As of March 31, 2009)

I. Membership Status: Joined December 28, 1945; Article VIII

II. General Resources Account:

Quota

Fund holdings of currency

Reserve position in Fund

III. SDR Department:

Net cumulative allocation

Holdings

$\begin{array}{rr}\begin{array}{r}\text { In millions } \\ \text { of SDRs }\end{array} & \begin{array}{r}\text { In percent } \\ \text { of Quota }\end{array} \\ 99.90 & 100.00 \\ 78.43 & 78.51 \\ 21.48 & 21.50\end{array}$

In millions

of SDRs

13.70

28.77
Percent of Allocation

100.00

210.02

IV. Outstanding Purchases and Loans: None

V. Latest Financial Arrangements:

$\begin{array}{lcccr}\text { Type } & \begin{array}{c}\text { Approval } \\ \text { Date }\end{array} & \begin{array}{c}\text { Expiration } \\ \text { Date }\end{array} & \begin{array}{c}\text { Amount Approved } \\ \text { (SDR Million) }\end{array} & \begin{array}{r}\text { Amount Drawn } \\ \text { (SDR Million) }\end{array} \\ \text { Stand-By } & \text { May 31, 2006 } & \text { Aug 31, 2008 } & 30.00 & 0.00 \\ \text { Stand-By } & \text { Dec 15, 2003 } & \text { Nov 30,2005 } & 50.00 & 0.00\end{array}$

\section{Projected Payments to Fund}

(SDR Million; based on existing use of resources and present holdings of SDRs):

Principal

Forthcoming

\begin{tabular}{lllll}
\hline 2009 & $\underline{2010}$ & $\underline{2011}$ & $\underline{2012}$ & $\underline{2013}$
\end{tabular}

Charges/Interest

0.00

0.00

0.00

0.00

0.00

Total

$\mathbf{0 . 0 0}$

$\mathbf{0 . 0 0}$

$\mathbf{0 . 0 0}$

$\mathbf{0 . 0 0}$

0.00

VII. Exchange Rate Arrangement: The currency of Paraguay is the Paraguayan guaraní. The exchange rate regime is a managed float. The exchange rate is determined in the interbank foreign exchange market, but the central bank intervenes in the foreign exchange and monetary markets to smooth out exchange rate fluctuations in real effective terms. The U.S. dollar is the principal intervention currency. On May 30, 2008, the average interbank rate for the U.S. dollar was $\mathbb{G} 4,070=\mathrm{US} \$ 1$. Paraguay has accepted the obligations of Article VIII, Sections 2(a), 3 and 4 of the Fund's Articles of Agreement.

VIII. Article IV Consultation: The Executive Board concluded the 2007 Article IV consultation on June 29, 2007. 


\section{Technical Assistance:}

Department Purpose Date of Delivery

MFD Reorganization of the Central Bank January 2004 and Monetary Operations

FAD Customs Administration Advisor July 2004-May 2005

MFD Monetary Operations and Monetary October 2004 Policy Formulation

MFD Public Banking Restructuring February 2005

FAD Customs and Tax Administration February 2005

MFD and WB FSAP Mission

April 2005 and July 2005

FAD Update of ROSC September 2005

STA ROSC January-February 2006

MFD Central Bank Recapitalization March 2006

MFD Peripatetic Banking Expert October 2005, February and August 2006

FAD Public Financial Management March 2006

FIN Safeguards Assessment March 2006

STA Consumer Price Index April-May 2006

FAD and LEG Tax Procedure Code May 2006

LEG Money Laundering July 2006

STA Monetary and Financial Statistics August-September 2006

MCM Payments System October 2006

$\begin{array}{lll}\text { STA Balance of Payments } & \text { November } 2006\end{array}$

FAD Revenue Administration December 2006

FAD Peripatetic Customs Advisor / May, August, and December 2007

Customs Administration

FAD Tax Code Regulations June 2007

MCM Development of Local Capital June 2007 Markets

MCM Banking Regulation and Supervision June, August, and November 2007

STA Quarterly National Accounts August 2007

STA Consumer Price Index August 2007 


$\begin{array}{lll}\text { Department } & \text { Purpose } & \text { Date of Delivery } \\ \text { STA } & \text { Monetary and Financial Statistics } & \text { November 2007 } \\ \text { MCM } & \text { Bank regulation and supervision } & \text { February - March 2008, June 2008 } \\ \text { FAD } & \begin{array}{l}\text { Tax Administration Strategic } \\ \text { Planning }\end{array} & \text { April 2008 } \\ \text { FAD } & \text { Tax Policy } & \text { August 2008 } \\ \text { STA } & \text { Quarterly National Accounts } & \text { August 2008 } \\ \text { FAD } & \text { Tax and Customs Administration } & \text { September 2008 } \\ \text { STA } & \text { Monetary and Financial Statistics } & \text { March 2009 }\end{array}$

X. Safeguards Assessment: Under the Fund's safeguards assessment policy, Central Bank of Paraguay (CBP) is subject to a full safeguard assessment in respect to the arrangement approved on May 31, 2006. A safeguards assessment of the CBP was completed in October 2006. The report stated that while the CBP has made some progress in strengthening the safeguards framework since the 2003 safeguards assessment, vulnerabilities remain in certain areas such as financial reporting and program data reporting to the Fund.

XI. Resident Representative: Mr. Tobias Roy has been a resident representative since December 2007. 


\section{Annex 2. Paraguay-World Bank Relations ${ }^{1}$}

(As of March 31, 2009)

The ongoing Country Assistance Strategy (CAS) was approved in December 2003. A new Country Partnership Strategy (CPS) will be submitted to the Board of Executive Directors for consideration on 5 May, 2009. The new CPS proposes an envelope of US $\$ 500$ million for FY09-FY13 and a rich non-lending program in the Government's priority areas. The CPS will be flexible to accommodate changing needs and priorities, and frontloaded to assist the authorities in addressing the global crisis. Recognizing that governance is at the forefront of the Government's reforms agenda, the CPS is focused on improving governance and building state institution, as well as reducing poverty and enhancing growth. A program for the initial two years of the CPS has been identified (US\$265 million).

At the moment the Bank's portfolio consists of two projects under implementation:

- $\quad$ Road Maintenance Project (US\$74 million, approved in FY07).

- $\quad$ Secondary Education Reform (US\$24 million, approved in FY04).

Two projects are awaiting effectiveness pending Parliamentary approval:

- $\quad$ Sustainable Agricultural Development (US\$37.5 million, approved in January 2008).

- $\quad$ Additional Financing for the Community Development project (US\$9.0 million, approved in FY08).

In addition, a Water and Sanitation Sector Modernization Project for US\$64 million is scheduled for consideration by the Bank's Board of Executive Directors on 14 April 2009. The four World Bank-financed projects presently under implementation or awaiting ratification by Parliament have a total value of US\$144.5 million in commitments, of which US\$119 million remain undisbursed as of March 31, 2009.

In addition to loans, the Bank has mobilized grants for the institutional strengthening of Congress (US\$0.4 million) and the Ministry of Finance (US\$0.3 million); for improving the management of indigenous lands (US\$1.7 million); to support social development in two municipalities (US\$0.9 million); to promote development in indigenous communities (US\$1.6 million), and to improve biodiversity and forestry (US\$0.3 million from the Institutional Development Fund and US\$0.3 million and US\$0.9 million from the Global Environment Fund). Paraguay has also elected to become a governance and anti-corruption (GAC) pilot country. On the analytical front, in FY07 the Bank completed a Land Tax Study and an Integrated Fiduciary Assessment (jointly with the Interamerican Development Bank and the European Union). A Secondary Education Attainment Assessment and the Policy

\footnotetext{
${ }^{1}$ Prepared by the staff of the World Bank.
} 
Notes for the New Administration were also completed in FY08. In FY09, the Bank completed a Mercosur Trade Study and a Transport Sector Assessment. A Fee for Services for the Payments System and a Programmatic Poverty Assessment (planned for FY09) are underway.

\section{Financial Relations With The World Bank}

(In millions of U.S. dollars)

\section{IBRD/IDA Active Operations (as of March 31, 2009)}

Committed

(Net of Cancellations) Disbursed Undisbursed

\section{Active loans}

Education Reform

24.0

74.0

37.5

Sustainable Agricultural Development

Pilot Community Development Project (AF)

Total active loans

Total IBRD/IDA ${ }^{2}$

Repaid

Total outstanding

$\mathrm{O} / \mathrm{w}$ IBRD (including exchange rate adjustment)

$\mathrm{O} / \mathrm{w}$ IDA

Disbursed Undisbursed

$\begin{array}{rr}22.5 & 1.5 \\ 3.0 & 74.0 \\ 0.0 & 37.5 \\ 0.0 & 9.0 \\ & \\ \mathbf{2 5 . 5} & \mathbf{1 1 9 . 0}\end{array}$

865.1

$797 . .0$

292.3

276.3

16.0

II. IFC Operations (as of March 31 2009)

$\begin{array}{lll}\text { Loans } & \text { Equity } & \text { Total }\end{array}$

$\begin{array}{llll}\text { Commitments } & 625 & 0.0 & 62.5\end{array}$

$\begin{array}{llll}\text { Held by IFC } & 0.0 & 0.0 & 0.0\end{array}$

Undisbursed

0.0

$0.0 \quad 0.0$

III. IBRD/IDA Loan Transactions (calendar year)

\begin{tabular}{lcccccccccc} 
& 1999 & 2000 & 2001 & 2002 & 2003 & 2004 & 2005 & 2006 & 2007 & 2008 \\
\hline Disbursements & 42.1 & 46.6 & 26.8 & 13.5 & 42.3 & 16.2 & 16.7 & 31.9 & 13.0 & 9.1 \\
Repayments & 24.6 & 20.2 & 15.3 & 16.8 & 21.0 & 34.8 & 26.6 & 27.5 & 27.5 & 29.9 \\
Net Lending & 17.5 & 26.4 & 11.5 & -3.3 & 21.3 & -18.5 & -9.9 & 4.3 & -14.5 & -20.7 \\
\hline
\end{tabular}

\footnotetext{
${ }^{2}$ As of March 31, 2009
} 


\section{AnNex 3. Paraguay-Inter-American DeVelopment BANK Relations ${ }^{1}$}

(As of March 31, 2009)

\section{Portfolio}

As of March 31, 2009, the active loan portfolio amounts to US\$654 million, with an undisbursed balance of US\$406 million. In addition, there are 60 active Technical Cooperation operations (regular TCs, MIF, and Small Projects) for US\$22.6 million, of which US\$15.5 million are undisbursed. There are also 6 trade facilities with the private sector up to US\$37 million. Loan approvals in 2009 are expected to total US\$470.6 million.

\section{Strategy}

A new IDB strategy for 2009-2013 is being prepared in accordance with the new government's priorities with special emphasis on social programs for poverty alleviation, infrastructure and public sector reform. It is expected to be anchored by the existing portfolio and will be front loaded for the new approvals.

\section{Pipeline}

The lending program for 2009 includes the following operations:

a. Second Program under the CCLIP Line for the Financing of the AFD, \$50 million.

b. National Program of Rural Roads Phase II, US\$65.6 million.

c. Sanitation for Rural Communities, SENASA, US\$52 million.

d. Public Management Modernization Program - Programmatic, US\$100 million.

e. Liquidity Program for Growth Sustainability in Paraguay, US\$200 million.

f. Trade Facilitation, Banco Amambay, US\$3 million.

Expected total 2009: US\$470.6 million.

\footnotetext{
${ }^{1}$ Prepared by the staff of the IDB.
} 


\section{AnneX 4. Paraguay-Statistical Issues}

Data provision to the Fund has some shortcomings, but is broadly adequate for surveillance. Following a data ROSC mission in January-February 2006, the authorities' response to the report and the mission's recommendations were published on the Fund's website on June 30, 2006. The country is a GDDS participant.

\section{A. Real Sector}

National accounts estimates, broadly consistent with the guidelines of the $1993 \mathrm{SNA}$, were released in 2005. However, no comprehensive regular program for data collection through economic censuses and surveys exists (an industrial survey was conducted in 2002) and source data for nonfinancial services, household consumption, and changes in inventories are insufficient. Major areas of concern include: (i) the 1994 reference year needs to be updated; (ii) excessive use is made of fixed coefficients for value added and household consumption;

(iii) changes in inventories are obtained residually; (iv) informal activities are not monitored; and (v) supply and use tables have been compiled only until 1997. While the periodicity of annual GDP meets GDDS recommendations, timeliness does not because data are disseminated with a lag of 11 months. An STA mission on the compilation of quarterly national accounts (QNA) was fielded in August 2007 and August 2008. Production of definite QNA series would need to await a revision of the national accounts base year and the compilation of supporting basic data, which are tentatively scheduled for completion by 2009/10.

Both the consumer (CPI) and producer price indices (PPI) are reported on a regular and timely basis. Since January 2008, the Central Bank of Paraguay (BCP) has been using a new CPI index based on the 2005-06 household budget survey. The geographic coverage of the CPI is limited to Asunción (the capital) and expenditure weights are representative of the consumption patterns of urban households. The PPI has a base weight period of December 1995 and its basket (150 items) is not fully representative of current national output; electricity, water, gas, and services are not covered.

Since the introduction of a regular household survey in 1998, the coverage and quality of employment and unemployment statistics have improved significantly. However, frequencies remain at the annual level, and the publication lag is close to one year. Wage indices are updated twice a year.

The data ROSC mission found that the resources are insufficient for real sector statistics and constrain further development, particularly the full adoption of the $1993 \mathrm{SNA}$. The authorities have been trying to address these resource shortcomings in the context of the recent compilation of a new CPI and the production of provisional QNA series. 


\section{B. Fiscal Sector}

The Government finance statistics (GFS) used for internal purposes and for reporting to WHD are broadly consistent with the recommendations of the Manual on Government Finance Statistics 1986 (GFSM 1986). The authorities have not yet prepared a plan to migrate to the Government Finance Statistics Manual 2001 (GFSM 2001). Monthly data are available for the central administration (budgetary central government). The asset position of the social security system is available on a daily basis. Statistics on the central administration include data of the Postal Service Directorate (a nonfinancial public corporation) and the statistics of the nonfinancial public sector include data of financial public corporations - four employer social insurance schemes. These social insurance schemes are treated as financial corporations in the monetary and financial accounts. Data on medium- and long-term external debt are reliable and available on a monthly basis. Domestic debt data are available on request, but need to be fully integrated with the external debt database. Deficiencies remain in recording short-term supplier and commercial credit of the public sector. Moreover, there is a discrepancy in the fiscal data reported by the monetary and fiscal authorities. Measures are being taken to make reporting more transparent.

Annual data covering general government for 2006 have been reported for publication in the 2007 edition of the GFS Yearbook. However, since 1994 no outstanding debt data and no breakdowns for expenditure by function have been provided for publication in the GFS Yearbook. Monthly and quarterly data are not reported for publication in IFS.

\section{Money and Banking Sectors}

Paraguay completed the establishment of a unified compilation and reporting system for the whole range of monetary data. This new system intends to harmonize monetary data for use within the BCP, for reporting to STA for publication in IFS, and for operational and monitoring purposes. A revision of the classification criteria has led also to a marked reduction in the discrepancies of interbank positions. However, the lack of coverage of the credit cooperatives remains a matter of concern since they account for around $1 / 4$ of deposits and loans of the banking sector. The BCP, with assistance from STA, plans to include monthly data of the 20 largest credit cooperatives in the monetary survey during 2009 . The Superintendency of Banks publishes a detailed and informative report on the soundness of the financial system.

\section{External Sector}

The classification of the balance of payments and the international investment position (IIP) follows the recommendations of the Balance of Payments Manual, 5th edition. Quarterly and annual data on balance of payments and the IIP are available from 2001 onwards on the central bank website, and are reported only once a year to STA for publication in the IFS. Improvements have been made in the quality of the data on capital flows, especially in the coverage of foreign direct investment, and in the recording of external debt transactions. 
Special studies by the central bank have improved the estimation methods for remittances of Paraguayans abroad and unregistered trade transactions, but serious deficiencies remain.

Also, there are deficiencies in the area of private capital outflows, which are difficult to register due to Paraguay's open capital account. An STA mission on Balance of Payments Statistics assisted the BCP in November 2006 in implementing recommendations of the ROSC mission. In particular, the mission focused on: (1) assessing the surveys used to capture data on services, direct investment, nonfinancial private sector portfolio investment, and other investment; (2) reviewing and updating the statistical techniques used to calculate unrecorded trade; (3) reassessing the treatment of the binational hydroelectric energy enterprises in the external sector accounts; and (4) reviewing and preparing a preliminary template for reporting data on international reserves and foreign currency liquidity. 
Paraguay: Table of Common Indicators Required for Surveillance

(As of March 31, 2009)

\begin{tabular}{|c|c|c|c|c|c|c|c|}
\hline & \multirow[b]{2}{*}{$\begin{array}{c}\text { Date of } \\
\text { latest } \\
\text { observation }\end{array}$} & \multirow[b]{2}{*}{$\begin{array}{l}\text { Date } \\
\text { received }\end{array}$} & \multirow[b]{2}{*}{$\begin{array}{c}\text { Frequency } \\
\text { of } \\
\text { Data }^{1}\end{array}$} & \multirow[b]{2}{*}{$\begin{array}{l}\text { Frequency } \\
\text { of } \\
\text { Reporting }^{1}\end{array}$} & \multirow[b]{2}{*}{$\begin{array}{l}\text { Frequency } \\
\text { of } \\
\text { publication }\end{array}$} & \multicolumn{2}{|c|}{ Memo Items: } \\
\hline & & & & & & $\begin{array}{l}\text { Data Quality } \\
\text { Methodological } \\
\text { soundness }^{7 /}\end{array}$ & $\begin{array}{l}\text { Data Quality } \\
\text { Accuracy and } \\
\text { reliability }^{8 /}\end{array}$ \\
\hline Exchange Rates & Mar. 2009 & 4/03/09 & $\mathrm{D}$ & $\mathrm{D}$ & $\mathrm{D}$ & & \\
\hline International Reserve Assets and Reserve Liabilities of the Monetary Authorities ${ }^{2}$ & Mar. 2009 & $4 / 03 / 09$ & $\mathrm{D}$ & M & $\mathrm{D}$ & & \\
\hline Reserve/Base Money & Feb 2009 & 3/30/09 & $\mathrm{D}$ & M & $\mathrm{D}$ & O, LNO, LO, O & $\mathrm{O}, \mathrm{O}, \mathrm{O}, \mathrm{LO}, \mathrm{LO}$ \\
\hline Broad Money & Feb. 2009 & $3 / 30 / 09$ & M & M & M & & \\
\hline Central Bank Balance Sheet & Feb. 2009 & $3 / 30 / 09$ & $\mathrm{D}$ & M & $\mathrm{D}$ & & \\
\hline Consolidated Balance Sheet of the Banking System & Feb. 2009 & $3 / 30 / 09$ & M & M & M & & \\
\hline Interest Rates $^{3}$ & Feb. 2009 & $3 / 30 / 09$ & M & M & M & & \\
\hline Consumer Price Index & Mar 2009 & $4 / 03 / 09$ & M & M & M & $\mathrm{O}, \mathrm{LO}, \mathrm{O}, \mathrm{O}$ & O, LO, LNO, O, LO \\
\hline $\begin{array}{l}\text { Revenue, Expenditure, Balance and Composition of Financing }{ }^{4}-\text { General } \\
\text { Government }{ }^{5}\end{array}$ & Feb. 2009 & $3 / 30 / 09$ & M & M & M & LO, LO, LO, LO & LO, LNO, O, LO, LO \\
\hline Stocks of Central Government and Central Government-Guaranteed Debt ${ }^{6}$ & Dec. 2008 & 3/30/09 & Q & Q & Q & & \\
\hline External Current Account Balance & Dec. 2008 & 3/30/09 & Q & Q & Q & O, LO, LO, LO & LO, O, LO, LO, LO \\
\hline Exports and Imports of Goods and Services & Dec. 2008 & 3/30/ 09 & M & M & M & & \\
\hline GDP/GNP & 2009 & $3 / 30 / 09$ & A & A & A & O, LO, LO, LO & LO, O, LNO, O, LO \\
\hline
\end{tabular}

${ }^{1}$ Daily (D); Weekly (W); Monthly (M); Quarterly (Q); Annually (A); Irregular (I); Not Available (NA).

${ }^{2}$ Includes reserve assets pledged or otherwise encumbered as well as net derivative positions.

${ }^{3}$ Both market-based and officially-determined, including discounts rates, money market rates, rates on treasury bills, notes and bonds.

${ }^{4}$ Foreign, domestic bank, and domestic nonbank financing.

${ }^{5}$ The general government consists of the central government (budgetary funds, extra budgetary funds, and social security funds) and state and local governments

${ }^{6}$ Including currency and maturity composition

${ }^{7}$ Reflects the assessment provided in the data ROSC published on June 30, 2006 and based on the findings of the mission that took place during January 25-February 8, 2006. For the dataset corresponding to the variable in each row. The assessment indicates whether international standards concerning (respectively) concepts and definitions, scope, classification/sectorization, and basis for recording are fully observed $(\mathrm{O})$, largely observed $(\mathrm{LO})$, largely not observed (LNO), or not observed (NO).

${ }^{8}$ Same as footnote 7, except referring to international standards concerning (respectively) source data, assessment of source data, statistical techniques, assessment and validation of intermediate data and statistical outputs, and revision studies. 


\section{INTERNATIONAL MONETARY FUND}

EXTERNAL

Public Information Notice

RELATIONS

DEPARTMENT

Public Information Notice (PIN) No. 09/64

FOR IMMEDIATE RELEASE

May 20, 2009

International Monetary Fund

$70019^{\text {th }}$ Street, NW

Washington, D. C. 20431 USA

\section{IMF Executive Board Concludes 2009 Article IV Consultation with Paraguay}

On May 1, 2009 the Executive Board of the International Monetary Fund (IMF) concluded the Article IV consultation with Paraguay. ${ }^{1}$

\section{Background}

The Paraguayan economy performed very well over the past five years, with real GDP growth averaging about 5 percent a year-the best in a generation. The fiscal position strengthened considerably, thereby reducing public debt sharply to relatively low levels. The economy grew by nearly 6 percent in 2008, but growth decelerated in the last quarter of the year. Paraguay's macroeconomic outlook has been negatively affected by the deterioration in the global environment. The agricultural sector has suffered from the decline in commodity prices, aggravated by the effects of a drought. Economic growth in 2009 is expected to decelerate to about $1 / 2$ percent. In part reflecting the weakening global environment, inflation in Paraguay is now on a firmly downward trend, and is projected at $5 \frac{1}{2}$ percent by end-2009, well within the Central Bank's target range. The budget recorded a sizeable surplus of $2 \frac{1}{2}$ percent of GDP in 2009, mainly on account of good revenue performance and low capital expenditure execution. However, tax revenue performance during the first quarter of 2009 has been lackluster, in part due to weak imports. The external current account deficit is expected to moderate to 1 percent of GDP, largely as a result of significantly lower imports, notwithstanding a decline in exports.

\footnotetext{
${ }^{1}$ Under Article IV of the IMF's Articles of Agreement, the IMF holds bilateral discussions with members, usually every year. A staff team visits the country, collects economic and financial information, and discusses with officials the country's economic developments and policies. On return to headquarters, the staff prepares a report, which forms the basis for discussion by the Executive Board. At the conclusion of the discussion, the Managing Director, as Chairman of the Board, summarizes the views of Executive Directors, and this summary is transmitted to the country's authorities.
} 
The government has reacted to the adverse economic conditions by adopting an Economic Recovery plan. This plan, which encompasses policies to address both immediate challenges and medium-term structural weaknesses, includes: (i) a fiscal stimulus of about 3 percentage points of GDP in 2009; (ii) steps to provide liquidity to the banking system to enhance lending; (iii) securing additional external financing from multilaterals (including contingent credit lines); and (iv) addressing key medium-term structural issues, including with respect to public financial management and financial sector reform.

The government's fiscal stimulus focuses on public investment in infrastructure and social programs, including targeted conditional cash transfers. Its full implementation would be consistent with an overall deficit of 3/4-1 percent of GDP in 2009, expected to be financed by disbursements from multilaterals and bilateral donors. Key to the success of the recovery program will be its effective and timely implementation, while transparent monitoring should help ensure that resources are spent efficiently.

\section{Executive Board Assessment}

While Paraguay has been affected by the global economic crisis, as other countries in the region, Executive Directors observed that the country faces the global downturn from a position of relative strength. The commendably prudent macroeconomic policies pursued in recent years have helped build significant buffers to address external shocks. Against the backdrop of a significant deterioration of the short-term outlook, Directors supported the authorities' economic priorities to consolidate macroeconomic stability, implement critical structural reforms, especially in the financial sector, and strengthen social conditions, with an emphasis on poverty reduction.

Directors concurred that the recent fiscal surpluses and decline in the public debt burden provide the government with a margin to conduct well-targeted counter-cyclical policies. They welcomed the authorities' economic recovery plan aimed at weathering the current crisis, and advised that the fiscal stimulus be focused on public investment and targeted social programs to reduce poverty. Directors underscored the need to improve public financial management and inter-ministerial coordination to ensure the plan's timely and effective implementation. Given the revenue shortfalls so far this year, Directors encouraged further improvements in tax and customs administrations, and recommended that the authorities refrain from granting tax concessions.

Executive Directors supported the current accommodative monetary policy, given the slowdown of the economy and the downward trend of inflation. Nonetheless, they recommended close monitoring of developments to enable the authorities to respond promptly to signs of inflationary or balance of payments pressures. They encouraged the authorities to press ahead with their efforts to strengthen the central bank's balance sheet to improve the effectiveness of monetary policy. Directors agreed that the flexible exchange rate regime continues to serve Paraguay well 
by acting as a shock absorber in the face of commodity price fluctuations and strong regional linkages. They noted the staff's assessment that the exchange rate is broadly in line with fundamentals.

Directors underscored the need to press ahead with structural reforms, especially in the financial and state-owned enterprise sectors. They welcomed the strengthening of the banking system, while recommending continued vigilance in the face of rapid credit growth. Directors encouraged the authorities to enhance significantly the regulation and supervision of financial cooperatives and retirement plans, given the large amounts of funds intermediated by these sectors. They also saw a need to improve the prudential framework for insurance companies. Directors welcomed the authorities' commitment to finance fully the Deposit Guarantee Fund. They emphasized the need to address operational and financial weaknesses of state-owned enterprises, which create significant bottlenecks in the productive capacity of the economy.

Public Information Notices (PINs) form part of the IMF's efforts to promote transparency of the IMF's views and analysis of economic developments and policies. With the consent of the country (or countries) concerned, PINs are issued after Executive Board discussions of Article IV consultations with member countries, of its surveillance of developments at the regional level, of post-program monitoring, and of ex post assessments of member countries with longer-term program engagements. PINs are also issued after Executive Board discussions of general policy matters, unless otherwise 
Paraguay: Selected Economic Indicators, 2004-09

\begin{tabular}{|c|c|c|c|c|c|c|}
\hline & 2004 & 2005 & 2006 & 2007 & $\begin{array}{r}\text { Est. } \\
2008\end{array}$ & $\begin{array}{l}\text { Proj. } \\
2009\end{array}$ \\
\hline \multicolumn{7}{|c|}{ Annual percent change; unless otherwise specified } \\
\hline \multicolumn{7}{|l|}{ National accounts and prices } \\
\hline GDP at current prices & 16.4 & 11.2 & 13.2 & 17.7 & 13.3 & 7.4 \\
\hline GDP at constant prices & 4.1 & 2.9 & 4.3 & 6.8 & 5.8 & 0.5 \\
\hline Per capita GDP (U.S. dollars, thousands) & 1.2 & 1.3 & 1.6 & 2.0 & 2.6 & 2.4 \\
\hline GDP deflator & 11.8 & 8.1 & 8.5 & 10.2 & 7.1 & 6.8 \\
\hline Consumer prices (end-of-period) & 2.8 & 9.8 & 12.5 & 5.9 & 7.5 & 5.5 \\
\hline \multicolumn{7}{|l|}{ Real effective exchange rate } \\
\hline Average (depreciation -) & 3.7 & -6.5 & 13.0 & 10.8 & 16.4 & $\ldots$ \\
\hline End-of-period (depreciation -) & -8.6 & 4.4 & 20.1 & 5.5 & 9.6 & $\ldots$ \\
\hline \multicolumn{7}{|c|}{ In millions of U.S. dollars } \\
\hline \multicolumn{7}{|l|}{ External sector } \\
\hline Exports, f.o.b. (percentage change) & 32.0 & 17.4 & 31.2 & 24.4 & 42.0 & -13.3 \\
\hline Imports, c.i.f. (percentage change) & 27.0 & 22.9 & 33.7 & 17.6 & 46.9 & -14.9 \\
\hline Current account & 143 & 19 & 45 & 82 & -227 & -153 \\
\hline (In percent of GDP) & 2.1 & 0.3 & 0.5 & 0.7 & -1.4 & -1.0 \\
\hline Capital account & 41 & 397 & 356 & 362 & 399 & 152 \\
\hline Overall balance & 277 & 147 & 402 & 762 & 321 & 0 \\
\hline Terms of trade (percentage change) & -1.4 & -9.9 & -2.3 & 6.2 & -1.1 & -5.1 \\
\hline \multicolumn{7}{|c|}{ In percent of GDP } \\
\hline \multicolumn{7}{|l|}{ Savings-investment balance } \\
\hline Gross domestic investment & 19.2 & 19.8 & 19.6 & 18.0 & 18.3 & 17.7 \\
\hline Private sector & 14.5 & 14.8 & 14.7 & 13.4 & 13.4 & 12.8 \\
\hline Public sector & 4.7 & 5.0 & 4.9 & 4.6 & 3.7 & 4.9 \\
\hline Gross national savings & 21.4 & 20.0 & 20.1 & 18.7 & 16.9 & 16.7 \\
\hline Private sector & 14.9 & 14.2 & 14.4 & 12.6 & 10.5 & 12.5 \\
\hline Public sector & 6.5 & 5.8 & 5.7 & 6.1 & 6.4 & 4.2 \\
\hline \multicolumn{7}{|l|}{ Public sector } \\
\hline Central government primary balance & 2.7 & 1.9 & 1.5 & 1.8 & 3.3 & 0.2 \\
\hline Central government overall balance & 2.0 & 0.6 & 0.1 & 0.9 & 2.6 & -0.7 \\
\hline Consolidated public sector primary balance $1 /$ & 3.2 & 2.8 & 3.7 & 3.4 & 3.9 & 0.3 \\
\hline Consolidated public sector overall balance $1 /$ & 1.8 & 0.9 & 0.8 & 1.5 & 2.7 & -0.7 \\
\hline Public sector debt (end-of-year) 2/ & 45.1 & 37.7 & 27.7 & 21.8 & 19.3 & 19.5 \\
\hline External & 40.9 & 34.3 & 25.3 & 19.9 & 17.5 & 17.8 \\
\hline Domestic & 4.2 & 3.4 & 2.4 & 1.9 & 1.8 & 1.7 \\
\hline Consolidated public sector debt $3 /$ & 48.8 & 42.7 & 34.1 & 28.2 & 23.8 & 21.7 \\
\hline \multicolumn{7}{|c|}{ Annual percent change } \\
\hline \multicolumn{7}{|l|}{ Money and credit } \\
\hline Monetary base & 17.6 & 4.3 & 13.0 & 35.3 & 18.1 & 25.4 \\
\hline M2 & 24.6 & 16.1 & 15.3 & 38.6 & 21.3 & 8.9 \\
\hline M5 3/ & 12.6 & 8.4 & 16.6 & 8.6 & 15.3 & 7.0 \\
\hline Credit to the private sector $4 /$ & 15.0 & 15.1 & 29.0 & 46.2 & 36.5 & 9.7 \\
\hline Velocity of M2 & 7.7 & 7.2 & 7.0 & 6.4 & 5.7 & 5.3 \\
\hline \multicolumn{7}{|l|}{ Memorandum items: } \\
\hline International reserves (in millions of U.S. dollars) & 1,168 & 1,297 & 1,703 & 2,462 & 2,864 & 2,864 \\
\hline (In months of imports) & 3.4 & 2.8 & 3.2 & 3.2 & 4.3 & 4.0 \\
\hline GDP (in billions of Guaranies) & 41,522 & 46,169 & 52,270 & 61,512 & 69,708 & 74,842 \\
\hline
\end{tabular}

Sources: Paraguayan authorities; and IMF staff estimates.

$1 /$ Consolidated public sector, including the quasi-fiscal operations of the BCP.

2/ Nonfinancial Public Sector. Based on end-of-period exchange rate conversion of U.S. dollar-denominated debt.

3/ Includes Central Bank Bills (LRMs).

4/ Foreign currency items are valued at a constant exchange rate. 


\section{Statement by David Vogel, Alternate Executive Director for Paraguay, and Jose Maciel, Advisor to Executive Director May 1, 2009}

On behalf of the Paraguayan authorities, we would like to thank the staff for a well-written report, which clearly highlights the country's robust economic performance and the challenges lying ahead. After the implementation of two Stand-By Arrangements, the country now faces the challenge to maintain the hard-earned macroeconomic stability and to keep advancing towards higher economic and social developments.

\section{General Remarks}

Last year's GDP growth reached 5.8 percent, averaging a 4.8 percent growth over the last 5 years, which is well above Paraguay's historical growth rate of 3.7 percent per annum. This outcome was possible thanks to the implementation of sound macroeconomic policies and structural changes, which have been helped by a positive external environment. Favorable commodity prices contributed to a great expansion of the agribusiness sector, which also benefited from exceptional weather conditions. However, the drop in these prices, together with a severe drought and the decline of the export meat markets due to the international crisis, has affected the continued expansion of the primary sector. Despite these unfavorable conditions, modest growth is still expected in 2009.

Presently, economic policies in Paraguay seek three objectives that are fully synergetic: to consolidate macroeconomic stability over the medium term; to continue the process of transforming the economy through critical structural reforms; and to significantly boost social conditions, with substantial emphasis on protecting the most vulnerable groups of society.

\section{Fiscal Sector}

The fiscal results attained in 2008 were remarkable, with a surplus of $2 \frac{1}{2}$ percent of GDP in the central government accounts. Tax revenues increased approximately 1 percent of GDP and current expenditures were adequately controlled. The prudent fiscal policies implemented in recent years and the relatively low public debt allow the authorities to undertake a fiscal stimulus plan aimed at coping with the economic slowdown stemming from the international crisis. In this regard, the 2009 budget includes increases in capital spending and also higher social spending to finance the conditional cash transfer program in order to reach 120,000 families. Precisely, the wage bill increase approved by Congress is largely the result of new personnel hired for health, education and security sectors, areas where social spending is much needed. 
Consistently, the Economic Reactivation Plan is the government's response to the crisis. The plan has been presented to different economic, social and political actors, with the objective of gaining social ownership. The overall cost of the plan is projected to reach 2-3 percent of GDP in 2009-2010. To finance the plan, the government is balancing the use of its domestic savings and external financing through the IDB, the World Bank, among others. The authorities are committed to closely monitoring the plan in order to ensure that it is welltargeted, transparent and coherent with the government's economic and social objectives.

The formulation and implementation of fiscal policy in the recent past have been oriented to achieve a coherent balance between taxes and public spending. On one hand, a system of low tax rates has been established, which is broad-based and easy to collect. The Personal Income Tax is the critical tool to attain the government's objective of increasing revenues. However, it was rejected by the Congress that passed a legislation to postpone its implementation until 2010. The President vetoed the bill and, apparently, there are not enough votes in Congress to overcome the veto, therefore, the income tax would be finally operational in Paraguay. ${ }^{1}$ On the other hand, there has been a great deal of improvement in tax administration, which has allowed a substantial increase in tax revenues and more transparency in the system, while critically reducing rent-seeking opportunities. The authorities are encouraged by the positive results achieved so far, although they are aware that much remains to be done.

\section{Monetary Sector}

Headline inflation reached 7.5 percent year-on-year in December 2008, within the upper limit of the Central Bank referential range. At end-March 2009, annualized inflation dropped to 3.4 percent as a consequence of the global economic slowdown and thanks to a coordinated management of monetary and fiscal policies. The authorities concur with the staff's projections for inflation in 2009 and 2010 (51/2 percent and 5 percent, respectively).

The above-referred inflation outlook has given room to the authorities to react promptly to the adverse economic conditions. In this vein, monetary policies have been eased and the Central Bank has injected liquidity into the financial system by lowering reserve requirements and by decreasing the interest rates of its sterilization instruments.

\section{Financial Sector}

The banking system remains solid and has become more stable following improvements in prudential regulations, notably the adoption of a new rule regarding portfolio classification and provisioning requirements, which was approved in 2007 but fully implemented by

\footnotetext{
${ }^{1}$ Congress needs an absolute majority of votes to prevail over the veto and confirm the bill.
} 
October 2008. The recent strengthening of the financial system and its limited exposure to foreign banks' credit had shielded the banking system from the global financial crisis. Although the projected drop in growth in 2009 could put a strain on the financial sector, as mentioned by the staff, the authorities believe that the impact would be significantly contained given the critical improvement in the regulation and supervision of the system. It is important to recall that recent banking crises in Paraguay, which are very well presented by the staff in Box 4 of the report, have led to conservative behavior, not only in supervisors, but also in bankers, who are more cautious when making loans. This also explains the stabilization of credit, which, starting from a very low base, is currently growing at a much lower rate than a year ago, as well as the low Non-Performing Loans ratio, which is currently at 1 percent. In general, the global credit crunch has had a limited impact on the financial system.

As noted, the regulatory and supervisory framework for banks and finance companies has been steadily improved since the last FSAP conducted in Paraguay, which has been an important contribution. Many improvements have been introduced in this area, and presently the degree of compliance with the Basel Core Principles for Effective Banking Supervision has substantially increased. During the recent Spring Meetings, the authorities requested an FSAP update, which is tentatively schedule for the spring of 2010.

The cooperative sector, especially the savings and loans cooperatives, is the main concern of the authorities and they are taking immediate actions to increase a more effective control on the sector. In this regard, the World Bank and the Inter-American Development Bank (IDB) are working together to assist the sector. Recently, the IDB approved a loan to provide technical assistance to strengthen the supervision and regulation of the cooperatives. Moreover, this issue was recently discussed by the Economic Cabinet, which created a National Technical Committee led by the Ministry of Finance to coordinate efforts and monitor the effectiveness of the resources provided by the IFIs. The authorities have also required the IMF's technical assistance on this matter.

The Deposit Guarantee Fund (FGD) - created by law in 2003 - is funded by banks and the State. Although there have been some delays, the government is committed to fulfilling its obligations. The government has already paid $\$ 20$ million and another $\$ 6$ million is budgeted for the present year, according to the schedule of payments approved by the authorities. Regarding bank restructuring and resolution, the same law that created the FGD has established the framework for bank resolution, which clearly identifies the responsibilities in case of troubled banks. In recent years, this framework was successfully used with the resolution of a finance company.

The implementation of the Payments System is a work in progress. On one hand, the legal framework is being prepared with the help of IMF and World Bank technical assistance. Once the Economic Cabinet approves the final draft of the bill, it will be sent to Congress. 
On the other hand, the Central Bank is going ahead with the acquisition of the technological equipment with the assistance of the World Bank. According to recent estimates, the system would be implemented by the second quarter of 2010 .

\section{External Developments}

After being in a strong position in the first semester of 2008 and despite a weaker global environment in the second semester, exports registered record levels in 2008. At the same time, the current account registered a deficit of $1 \frac{1}{2}$ percent of GDP at the end of the year. The guarani had appreciated by 17 percent annually by September 2008, and the Central Bank of Paraguay had accumulated record levels of international reserves. The trend shifted between then and March 2009, and the Central Bank had to intervene in the exchange market to avoid a sharper depreciation of the currency. Presently, the guarani is stabilized at around the same level it was a year ago, and the international reserves at the Central Bank have been increasing to almost $\$ 3$ billion, the equivalent to $4 \frac{1}{4}$ months of imports. The authorities agree with the staff's appraisal that the guarani exchange rate is in line with fundamentals.

The projected bill to use international reserves to fund fiscal expenditures, as mentioned in the staff report, was promptly deactivated by the monetary authorities, who approached Congress to explain the issue. At present, the draft bill has been withdrawn from Congress.

The new government is firmly committed to resolve the issue of international dispute claims. The General Attorney of the Republic and the Legal Advisor to the Treasury are working together to find a resolution to the cases in dispute.

\section{Final Remarks}

Paraguay has benefited considerably from Fund programs and its technical assistance. The authorities consider that the sound macroeconomic policies and structural reforms consistent with the Fund's advice allow the country to be well positioned to face the current global crisis. Prudent fiscal and monetary management in recent years permitted a continued decline in the debt ratio and substantial savings that now give the country the possibility of implementing a stimulus plan to cope with the declining growth prospects.

The authorities are well aware of the challenges ahead, but they are determined to continue working towards improving the business climate and promote investment, thus achieving higher and sustainable economic and social developments. Finally, they would like to thank

the staff and Management for their continuous support and advice, and they are committed to maintain the ongoing policy dialogue. 